\title{
Permafrost conditions in the Mediterranean region since the Last Glaciation
}

DOI:

10.1016/j.earscirev.2018.06.018

\section{Document Version}

Accepted author manuscript

Link to publication record in Manchester Research Explorer

\section{Citation for published version (APA):}

Oliva, M., Žebre, M., Guglielmin, M., Hughes, P. D., Çiner, A., Vieira, G., Bodin, X., Andrés, N., Colucci, R. R., García-hernández, C., Mora, C., Nofre, J., Palacios, D., Pérez-alberti, A., Ribolini, A., Ruiz-fernández, J., Sarkaya, M. A., Serrano, E., Urdea, P., ... Yldrm, C. (2018). Permafrost conditions in the Mediterranean region since the Last Glaciation. Earth-Science Reviews, 185, 397-436. https://doi.org/10.1016/j.earscirev.2018.06.018

\section{Published in:}

Earth-Science Reviews

\section{Citing this paper}

Please note that where the full-text provided on Manchester Research Explorer is the Author Accepted Manuscript or Proof version this may differ from the final Published version. If citing, it is advised that you check and use the publisher's definitive version.

\section{General rights}

Copyright and moral rights for the publications made accessible in the Research Explorer are retained by the authors and/or other copyright owners and it is a condition of accessing publications that users recognise and abide by the legal requirements associated with these rights.

\section{Takedown policy}

If you believe that this document breaches copyright please refer to the University of Manchester's Takedown Procedures [http://man.ac.uk/04Y6Bo] or contact uml.scholarlycommunications@manchester.ac.uk providing relevant details, so we can investigate your claim.

\section{OPEN ACCESS}




\begin{abstract}
The relatively warm climate conditions prevailing today in the Mediterranean region limit cold geomorphological processes only to the highest mountain environments. However, climate variability during the Late Pleistocene and Holocene has led to significant spatio-temporal variations of the glacial and periglacial domain in these mountains, including permafrost conditions. Here, we examine the distribution and evolution of permafrost in the Mediterranean region considering five time periods: Last Glaciation, deglaciation, Holocene, Little Ice Age (LIA) and present-day. The distribution of inactive permafrost-derived features as well as sedimentary records indicates that the elevation limit of permafrost during the Last Glaciation was between $1000 \mathrm{~m}$ and even $2000 \mathrm{~m}$ lower than present. Permafrost was also widespread in non-glaciated slopes above the snowline forming rock glaciers and block streams, as well as meter-sized stone circles in relatively flat summit areas. As in most of the Northern Hemisphere, the onset of deglaciation in the Mediterranean region started around 19-20 ka. The ice-free terrain left by retreating glaciers was subject to paraglacial activity and intense periglacial processes under permafrost conditions. Many rock glaciers, protalus lobes and block streams formed in these recently deglaciated environments, though most of them became gradually inactive as temperatures kept rising, especially those at lower altitudes. Following the Younger Dryas glacial advance, the Early Holocene saw the last massive deglaciation in Mediterranean mountains accompanied by a progressive shift of permafrost conditions to higher elevations. It is unlikely that air temperatures recorded in Mediterranean mountains during the Holocene favoured the existence of widespread permafrost regimes, with the only exception of the highest massifs exceeding 2500$3000 \mathrm{~m}$. LIA colder climate promoted a minor glacial advance and the spatial expansion of permafrost, with the development of new protalus lobes and rock glaciers in the highest massifs. Finally, post-LIA warming has led to glacial retreat/disappearance, enhanced paraglacial activity, shift of periglacial processes to higher elevations, degradation of alpine permafrost along with geoecological changes.
\end{abstract}

Key words: Mediterranean region, permafrost, Last Glacial Maximum, deglaciation, Holocene. 


\section{Permafrost conditions in the Mediterranean region since the Last Glaciation}

M. Oliva'; M. Žebre'; M. Guglielmin ${ }^{3}$; P.D. Hughes ${ }^{4}$; A. Çinerr ${ }^{5}$; G. Vieira ${ }^{6}$; X. Bodin ${ }^{7}$; N. Andrés ${ }^{8}$; R.R. Colucci ${ }^{9}$; C. García-Hernández ${ }^{10}$; C. Mora ${ }^{6}$; J. Nofre ${ }^{11}$; D. Palacios ${ }^{8}$; A. PérezAlberti $^{12}$; A. Ribolini ${ }^{13}$; J. Ruiz-Fernández ${ }^{10}$; M.A. Sarıkaya ${ }^{5}$; E. Serrano ${ }^{14}$; P. Urdea ${ }^{15}$; M. Valcárcel $^{12}$; J.C. Woodward ${ }^{4}$; C. Y1ldırım ${ }^{5}$

(1) Department of Geography, University of Barcelona, Spain

(2) Geological Survey of Slovenia, Slovenia

(3) Department of Theoretical and Applied Sciences, Insubria University, Italy

(4) Department of Geography, The University of Manchester, United Kingdom

(5) Eurasia Institute of Earth Sciences, Istanbul Technical University, Turkey

(6) CEG - Institute of Geography and Spatial Planning, Universidade de Lisboa, Portugal

(7) Environment Dynamics and Territories of Mountains (EDYTEM), University of Grenoble, France

(8) Department of Geography, Complutense University of Madrid, Spain

(9) Department of Earth System Sciences and Environmental Technologies, ISMAR-CNR, Italy

(10) Department of Geography, University of Oviedo, Spain

(11) Interdisciplinary Centre of Social Sciences, New University of Lisbon, Lisbon

(12) Department of Geography, University of Santiago de Compostela, Spain

(13) Department of Earth Sciences, University of Pisa, Italy

(14) Department of Geography, University of Valladolid, Spain

(15) Department of Geography, West University of Timisoara, Romania

\section{* Corresponding author}

Marc Oliva, oliva_marc@yahoo.com

Department of Geography

Faculty of Geography and History, University of Barcelona

c/ Montalegre 6, 08001 - Barcelona, Spain

Tel: ++34 616104266 


\section{Introduction}

Permafrost is one of the elements of the cryosphere with the widest global distribution. The area occupied by permafrost in both hemispheres varies according to different authors between $22.10^{6}$ $\mathrm{km}^{2}\left(17 \%\right.$ of the Earth's exposed land surface; Gruber, 2012) and $36.10^{6} \mathrm{~km}^{2}(24 \%$; French, 2007). Terrestrial ecosystems in many ice-free areas at high latitudes and in high mountains are conditioned by the presence of permafrost. Additionally, permafrost has an influence on the socioeconomic activities of these areas, especially those related to the construction and maintenance of all kinds of equipment and infrastructures (Nelson et al., 2001, 2002; Bommer et al., 2010). However, as a research topic, permafrost has received much less global attention than other elements of the cryosphere, such as glaciers, which are highly visible elements in the landscape and carry important hydrological and global sea level consequences (e.g. Favier et al., 2014; Smith et al., 2017), and sea ice due to its influence on ocean-atmospheric interactions (e.g. Curran et al., 2003; Robinson et al., 2012) and geopolitical implications across the Arctic (Østerud and Hønneland, 2014).

As a result of the International Polar Year 2007-2008, there has been an important development in the study of the thermal state and current distribution of permafrost (Lewkowicz, 2010) and the active layer (Oliva et al., 2017), along with their geoecological implications (Jorgenson et al., 2001; Jorgenson and Osterkamp, 2005; Genxu et al., 2006). Most studies have focused mainly on the Arctic (e.g. Mackay, 2000; Brown et al., 2001; Lantuit et al., 2012; Fritz et al., 2017), but also on Antarctica (e.g. Vieira et al., 2010; Bockheim et al., 2013; Guglielmin et al., 2014; Oliva and Ruiz-Fernández, 2015) and mountainous areas with increased population and tourism pressure (e.g. Alps, Haeberli and Beniston, 1998; Boeckli et al., 2012). Permafrost degradation as the consequence of recent global warming is already posing risks and problems to certain socioeconomic activities in many areas (Nelson et al., 2001, 2002; Ravanel, et al., 2017). Besides, during the last decade, scientists have pointed out the importance of permafrost not only at the local and regional level, but also at global scale examining the role of permafrost thawing in the carbon cycle and greenhouse gas fixation, as well as its contribution to recent and future climatic evolution (e.g. Hugelius et al., 2014; Zubrzycki et al., 2014; Schuur et al., 2015).

From a geographical perspective, the thermal state and distribution of permafrost have been much less studied in environments such as mountain ranges in the mid-latitudes. This is the case of the high mountains of the Mediterranean basin, where knowledge about the thermal dynamics, depth and extent of permafrost is uneven across the region.

The Mediterranean region is a transition zone between the subtropical climatic area and temperate regions more characteristic of the middle latitudes (Woodward, 2009). This region has its own climatic characteristics, conditioned by the presence of a nearly closed sea (the Mediterranean), and a complex and mountainous landscape defined by the existence of large peripheral mountain ranges, rugged coasts, and many islands and archipelagos. Most research on cold processes in the Mediterranean mountains has focused on the Quaternary glaciations (Hughes et al., 2006a, 2007, 2013; Hughes and Woodward, 2008), while permafrost and periglacial processes have been less examined (Hughes and Woodward, 2009). Thus, knowledge of the distribution of permafrost in this basin in the past is limited to generic maps that represent the area occupied by permafrost in the Northern Hemisphere during the Last Glacial Maximum (LGM; 26.5-20/19 ka (Clark et al., 2009); 27.5-23.3 ka (Hughes and Gibbard, 2015), as a complement to glacial extent (Brown et al., 2001, Vandenberghe et al., 2014; Kitover et al., 2016). However, the Mediterranean region is loosely represented in these maps since permafrost areas are barely included, except for certain areas such as the Alps and the SE coast of France. Besides, knowledge of the distribution of permafrost following the LGM and throughout the Holocene is limited and geographically sparse. 
As far as the current dynamics are concerned, the existing studies on permafrost and related periglacial morphodynamics mainly concentrate on the southern slope of the Alps and the Pyrenees (Guglielmin et al., 1994; Hoelzle, 1996; Dramis et al., 1995; Ikeda and Matsuoka, 2002; Lugon et al., 2004; Julián and Chueca, 2007; Serrano et al., 2009, 2010; Colucci et al., 2016a), and to a much lesser extent on other massifs, such as the Sierra Nevada (Gómez-Ortiz et al., 2001, 2014; Oliva et al., 2016b) and the Atlas (Vieira et al, 2017).

In consequence, permafrost studies in the Mediterranean region are spatially limited and temporally dispersed. Thus, it is essential to encourage detailed reflection on the state of knowledge of permafrost in this region, and identify the areas and periods in which research on this topic needs to be intensified. Accordingly, the general aim of this article is to fill this gap by looking into the spatial distribution of permafrost in the mountains of the Mediterranean region since the Last Glaciation, which is defined by the last cold stage (Weichselian/Würmian; marine isotope stage (MIS) 5d-2), to the present day. To meet this aim, the following specific objectives will be addressed:

- Reconstructing the spatio-temporal evolution of permafrost in this region since the Last Glaciation.

- Identifying the Mediterranean areas where permafrost has been studied.

- Determining the best-known permafrost stages and those with knowledge gaps.

- Pointing out future lines of work to the scientific community centred on the study of permafrost in the Mediterranean mountains.

- Discussing the distribution of the spatio-temporal pattern of the areas affected by permafrost and its associated geomorphological processes within the climatic and environmental evolution recognised on the European continent since the Last Glaciation.

\section{Regional setting}

Extending over a surface of ca. 2.5.106 $\mathrm{km}^{2}$ (Jeftic et al., 1989), the Mediterranean constitutes an almost enclosed basin between southern Europe (north), Anatolia (east), northern Africa (south) and the Iberian Peninsula (west), only connected to the Atlantic Ocean through the Strait of Gibraltar (ca. $15 \mathrm{~km}$ wide). Etymologically, Mediterranean derives from the Latin 'medius' (middle) and 'terra' (land), highlighting one of the main characteristics of the Mediterranean region: the presence of mountains next to the sea (Figure 1). Several volcanoes and mountain ranges with elevations exceeding 2500-3000 $\mathrm{m}$ asl stretch a few $\mathrm{km}$ off the coastline (Table 1).

Figure 1

Table 1

The Mediterranean basin is located in a boundary position between the mid-latitude westerlies and the influence of continental and subtropical high-pressure systems. The existence of multiple peninsulas, islands, rugged coastlines and mountain ranges determines a broad spectrum of climate regimes across the region, both in terms of temperatures and precipitation (Figure 1). This results in a wide range of hydrological, edaphic, geomorphological and biological processes prevailing in the Mediterranean region.

A broad variety of marine and terrestrial records preserve evidence of the nature and magnitude of Quaternary climate oscillations driving environmental changes in the Mediterranean basin (Woodward, 2009). Climate changes also determined large social transformations transitioning 
from the prehistoric inhabitants to the first sedentary agricultural communities that settled in the fertile soils of the Mediterranean lowlands (Mithen, 2004). The topographic configuration of the Mediterranean and its relief, together with relatively warm climate conditions during the Holocene, favoured the development of early civilizations, agriculture flourishing and trade and cultural exchange. Human-induced activities, together with shifts on ecosystem dynamics promoted by climate fluctuations, substantially affected the Mediterranean landscape, particularly since the Mid-Holocene, accelerating over the last few centuries.

Quaternary climate variability has followed different spatio-temporal patterns across the Mediterranean basin, which resulted in changing cold-climate geomorphological processes occurring in the mountains of the region. Glacial and periglacial activity has shaped the highest environments during the Late Pleistocene (Hughes and Woodward, 2016). The timing and spatial extent of glacial processes was highly conditioned by the combination of cold and moisture regimes, with significant spatio-temporal differences between the areas (Hughes et al, 2006a,b; Hughes and Woodward, 2008). Periglacial activity followed a similar pattern, expanding downvalleys during glaciations and shifting to higher elevations during interglacial periods (Oliva et al., 2016b). Though periglacial processes in Mediterranean mountains are currently mostly related to seasonal frost, environments affected by permafrost conditions in the past were significantly larger as suggested by a wide range of records that will be examined in detail in this research.

\section{Methodology}

This paper presents a detailed analysis of the published scientific literature on permafrost evolution in the Mediterranean region since the Last Glaciation. To better examine spatial and temporal patterns of permafrost conditions within the region, the Mediterranean basin has been subdivided in the following areas: Iberian Peninsula, southern Alps, Italian Peninsula, Balkan Peninsula, Anatolian Peninsula, northern Africa and Mediterranean islands (Figure 1).

For each of the areas we have conducted a detailed review of all the existing knowledge on permafrost conditions focusing on five main periods: Last Glaciation, deglaciation, Holocene, LIA and present-day. We establish the chronological boundary between the Last Glaciation and the deglaciation at 19-20 ka, after the LGM, when Clark et al. (2009) proposed the onset of deglaciation in the Northern Hemisphere, including also the Mediterranean region. We recognise that glaciers reached their maxima at different times during the Last Glaciation and glaciers in some areas retreated to smaller positions earlier than others, but the widespread deglaciation occurred after 19-20 ka in all parts of the Mediterranean mountains. The deglaciation extends until the Holocene and is divided considering different colder/warmer periods, sometimes characterised by phases of glacier advance/retreat, namely the Oldest Dryas (OD; 17.5-14.7 ka, stadial GS-2.1a), Bølling-Allerød (BA; 14.7-12.9 ka, interstadial GI-1) and Younger Dryas (YD; 12.9-11.7 ka, stadial 1 - GS1). The Holocene is subdivided following Walker et al. (2012) who established the limit between Early-Middle Holocene at $8.2 \mathrm{ka} \mathrm{BP}$ and the boundary between the Middle-Late Holocene at $4.2 \mathrm{ka} \mathrm{BP}$. The LIA is defined as a single period within the Late Holocene encompassing from the 14th to 19th centuries, followed by the post-LIA warming. The characterization of current permafrost distribution and associated geomorphic processes in Mediterranean mountains allows comparing present-day dynamics with past permafrost conditions. 
All these data have been summarized in a table including the location of the massifs, topographic characteristics (elevation, aspect), geomorphic evidence, available chronology (if existing) and associated references for each region. The distribution of permafrost-related features in each of the areas for each of the study periods has been mapped in GIS environment.

Rock glaciers constitute the most frequent and reliable information on palaeo-permafrost occurrence in Mediterranean mountains (Oliva et al., 2016b). Several fossil rock glaciers have been dated by analyzing the exposure of surfaces to cosmogenic radiation, usually by the presence of ${ }^{36} \mathrm{Cl}$ or ${ }^{10} \mathrm{Be}$ isotopes in the rock surface (i.e. Ciner et al., 2017). Two approaches have been generally used for inferring the age of rock glaciers: (i) their maximum age of formation has been often determined from samples collected from polished bedrock outcrops in which the rock glacier lies, (ii) their minimum age of stabilization has been also established based on samples taken from the surfaces of boulders distributed from the front of the rock glacier to the roots in the slope. Therefore, following this approach the dated samples should yield younger ages from the rock bedrock outcrops towards the roots of the rock glacier, which in fact has happened in most cases. However, there are still many unsolved issues concerning the application of surface exposure dating on rock glaciers, mainly related to: (i) the timing between boulders (i.e. rock glacier) stabilization and permafrost disappearance, (ii) the paleoclimatic significance of rock glacier activity in very active geomorphological settings experiencing paraglacial readjustment (Ballantyne et al., 2009; Palacios et al., 2016, 2017b; Andrés et al., 2018), (iii) the problem of excessive inherited nuclides yielding too old ages (Ivy-Ochs et al., 2009; Çiner et al., 2017) contrary to the moraines where glacial carving removes the cosmogenic inheritance, and last but not least (iv) the problem related to toppling and/or erosion of boulders that result in too young ages (e.g. Moran et al., 2016).

\section{Geomorphological and sedimentological evidence}

\subsection{Iberian Peninsula}

The Iberian Peninsula constitutes the SW tip of the Eurasian continent between the Atlantic Ocean and the Mediterranean Sea. Relatively flat terrain is mostly located in the central plateaus and coastal plains, separated by several mountain ranges aligned W-E with the highest peaks exceeding $2000 \mathrm{~m}$ : NW ranges, Cantabrian Mountains, Pyrenees, Central Range, the Iberian Range and the Betic Range (Figure 2). The rough terrain together with the high elevations have conditioned the magnitude and extent of glacial and periglacial processes during the Quaternary, including substantial variations of the spatial domain of permafrost through time. Sierra Nevada, in the Betic Range (Mulhacén, 3478 m), and the Maladeta massif, in the Pyrenees (Aneto, 3404 $\mathrm{m}$ ) encompass the highest elevations in Western Europe outside the Alps.

A wide range of lithologies is found across Iberia. While some mountain regions show a relatively homogeneous composition - such as the NW ranges, Central Iberian Range and Iberian Range with prevailing metamorphic and crystalline rocks - or the Cantabrian Mountains with widespread thick Mesozoic carbonates -, others include a variety of rocks - such as the Pyrenees and the Betic Range with alternating Palaeozoic crystalline rocks and Mesozoic carbonates.

Quaternary periglacial activity has been more or less intense and extensive in the Iberian Peninsula in response to prevailing climate conditions. The intensity and duration of the cold determined if periglacial processes were conditioned by the presence of permafrost or seasonal frost conditions. This is also reflected in the widespread geomorphological and sedimentological 
features of periglacial origin in mid and high mountain environments in Iberia, but also at lower elevations such as in the NW corner and Cantabrian coast where periglacial activity almost reached sea level.

\section{Last Glaciation}

Although the chronology of periglacial activity in the Iberian Peninsula during the Last Glaciation is still uncertain (Oliva et al., 2016a), it is likely to consider that its extent and intensity followed periods of glacial advance and retreat. In this sense, the local Maximum Ice Extent (MIE) occurred asynchronously across Iberian mountain ranges: while the combination of cold and moisture was more effective for glacier development in NW Iberia between 35 and $45 \mathrm{ka}$ cal BP (Valcárcel, 1998; Jiménez and Farias, 2002; Moreno et al., 2010; Serrano et al., 2012, 2013, 2015; Jiménez et al., 2013; Rodríguez-Rodríguez et al., 2014, 2016; Nieuwendam et al., 2016; Ruiz-Fernández et al., 2016), in the Central and some sectors of the Eastern Pyrenees it occurred prior to the LGM, probably at approximately 60 ka cal BP (García-Ruiz et al., 2003, 2010, 2013; Lewis et al., 2009; Delmas, 2015), in Sierra Nevada it took place around 30-32 ka (Gómez-Ortiz et al., 2012a, 2015; Oliva et al., 2014; Palacios et al., 2016) and in the rest of high mountain ranges, also in the Eastern Pyrenees, was slightly earlier or almost synchronous with the Last Glacial Maximum (LGM) (Pallàs et al., 2006; Domínguez-Villar et al., 2013; Hughes et al., 2013; Pedraza et al., 2013; Carrasco et al., 2015; Palacios et al., 2015). During the coldest stages of the Last Glaciation (e.g. MIS 2) glaciers extended across the highest mountain ranges in Iberia and periglacial processes expanded to the lowlands; warmer phases favoured periglacial activity only in mountain environments in parallel to glacier shrinkage.

Periglacial processes in mid and low environments were mainly driven by seasonal frost conditions, though some researchers have found evidence of ice wedge development in Pleistocene fluvial terraces between 200 and $1000 \mathrm{~m}$ in the Tajo and Duero basins, central Iberia, which may be related to very intense periglacial conditions but probably not associated with a permafrost regime (Badorrey et al., 1970; Asensio-Amor and González-Martín, 1974; Serrano et al., 2010a). Taking into account the presence of block streams and rock glaciers, the non-glaciated slopes of Iberian mountains were affected by permafrost conditions above 700-1300 $\mathrm{m}$ in northern mountain ranges (Figure 2), significantly higher in lower latitude mountain ranges, such as the Central Range (1800 m) and Sierra Nevada (2500 m) (Table 2). Sediments of periglacial origin, such as stratified and head deposits, could have been also produced under permafrost conditions, namely in the highest slopes and during the coldest stages. The presence of meter-sized patterned ground features, such as the sorted circles existing across the summit plateaus of most of the mountain ranges (Pyrenees, Sierra Nevada, Cantabrian Mountains), suggests also very intense periglacial conditions in these relatively flat areas where wind redistribution did not favour snow accumulation.

Figure 2

\section{Deglaciation}

As in many other glaciated environments in the Northern Hemisphere (Clark et al., 2009), a rapid deglaciation process started in Iberian mountains around 19-20 ka (Hughes and Woodward, 2008; García-Ruiz et al., 2010) at the same time as in mountain areas bordering the NE Atlantic to the north (Hughes et al., 2016). The terrain exposed by retreating glaciers was subject to paraglacial activity and intense periglacial processes under permafrost conditions. Many rock glaciers, protalus lobes and few block streams formed in recently deglaciated environments, though most 
of them became gradually inactive as temperatures kept raising, namely those located at lower altitudes (Table 2).

Table 2

However, the deglaciation was not a linear process and glacial expansion occurred in the highest mountain ranges during two major cold periods before the Holocene, namely the OD and YD. Following each of these cold stages, rock glaciers developed inside the cirques and highest slopes. As temperatures rose, rock glaciers became inactive at lower elevations with activity only at higher locations; in the case of the Pyrenees, rock glaciers formed during the OD at elevations above $2250 \mathrm{~m}$ with widespread permafrost above $2490 \mathrm{~m}$, while during the YD rock glaciers developed above $2350 \mathrm{~m}$ and permafrost was limited to elevations above $2525 \mathrm{~m}$ (Oliva et al., 2016a). Many rock glaciers in the Cantabrian Mountains have been assigned to this period (Redondo et al., 2010; Gómez-Villar et al., 2011; Pellitero et al., 2011; García-Ruiz et al., 2016a,b), as well as in the Iberian Range, where several rock glaciers were also related to this period in the Cebollera Sierra (Ortigosa, 1986), and in the Demanda Sierra (García-Ruiz et al., 1979; Fernández-Fernández et al., 2017). Surface exposure dating suggests that rock glaciers were active in the Eastern Pyrenees between 15 and 10.5 ka (Palacios et al., 2015; García-Ruiz et al., 2016a,b) and in the Sierra Nevada from 12.8 to 6.4 ka (Gómez-Ortiz et al., 2012a; Palacios et al., 2016). Patterned ground probably related to permafrost conditions may have been active during the coldest stages of the OD and YD in the high lands of the highest mountain ranges.

\section{Holocene}

The onset of the Holocene saw the last massive deglaciation in Iberian mountains that was parallel to a progressive shift of periglacial conditions to higher elevations (Oliva et al., 2011). It is unlikely that the atmospheric temperatures recorded in Iberian mountains during the Holocene favoured the existence of widespread permafrost regimes (Oliva et al., 2016b), with the only exception of the highest massifs in the Pyrenees (Serrano, 1998). In the other highest mountain ranges permafrost conditions during the Holocene may have been marginal and only related to favourable geomorphological settings.

The Pyrenees, Cantabrian Mountains and Sierra Nevada were the only environments encompassing glaciers during the coldest stages of the present-day interglacial. Apart from the LIA glaciation, Gellatly et al. (1992) dated a cold phase in the Troumouse cirque (French Pyrenees) between 4.6 and $5.1 \mathrm{ka}$ cal BP and García-Ruiz et al. (2014) reported evidence of glacier activity in the Pyrenees during the Neoglacial (5.1, $3.5 \mathrm{ka})$ and Dark Ages (1.4-1.2 ka) periods. Based on denudation rates, debris supply from cirque walls and flow displacement rates, Serrano et al. $(2006,2011)$ suggested that some active rock glaciers today in the Pyrenees (i.e. Argualas, Bastampé, Besiberri and Guerreys) probably developed between 3.4 and $6.2 \mathrm{ka}$; therefore, during part of the Mid Holocene permafrost environments may have existed in the highest mountains. This stage of rock glacier development seems to correlate with Neoglacial cold phases favouring glacial expansion in the Troumouse cirque (Gellatly et al., 1995) and Monte Perdido massif (García-Ruiz et al., 2014). The morphology and internal stratigraphy of the rock glaciers, some of which reshaped by LIA glacial advance, suggests that at least seven currently active rock glaciers originated during the Mid Holocene (Serrano et al. 2002, 2010b, 2011). Ice caves in the Central Pyrenees also started forming during the Mid Holocene, namely between 6 and 2 ka cal BP (Sancho et al., 2016). 
In Sierra Nevada, Oliva and Gómez-Ortiz (2012) also identified glacial advances during the Neoglacial period (2.8-2.7 ka cal BP) and Dark Ages (1.4-1.2 ka cal BP). These glacial conditions were accompanied by an extent of periglacial activity, enhanced erosion processes and decrease of vegetation cover (Oliva-Urcía et al., 2013), with permafrost conditions only in the highest parts of the glacial cirques (Oliva and Gómez-Ortiz, 2012). The existence of permafrost was confirmed by surface exposure dating in some areas such as in Sierra Nevada, where rock glaciers were active until the Mid Holocene in favourable topographic environments inside the YD glaciated cirques (Palacios et al., 2016). In some cases, the development of protalus lobes during the Holocene may be also indicative of permafrost conditions (Table 2).

\section{LIA}

In Iberia, colder than present-day climate conditions accompanied by fluctuating precipitation prevailed during the LIA (Barriendos, 1997; Rodrigo, 1999). These conditions led to glacial advance in the Pyrenees, as well as the appearance of small glacial spots in the Cantabrian Mountains and Sierra Nevada (González-Trueba, 2006, González-Trueba et al., 2008; GómezOrtiz et al., 2006, 2009; Oliva and Gómez-Ortiz, 2012). Periglacial conditions expanded downvalleys and more extensive snow fields remained during the summer season. Permafrost conditions reactivated and new protalus lobes and rock glaciers formed in the Pyrenees above $2560 \mathrm{~m}$ (Serrano et al., 2001, 2011; Fernandes et al., 2017). Several currently active rock glaciers are linked with LIA lateral moraines, suggesting their origin following the LIA in historical times. All of them are relatively small and influenced by glaciers, which indicates the elevation boundary of permafrost conditions above 2560 m (Serrano, 1998; Serrano et al., 2004, 2011; GonzálezGarcía, 2014). With the exception of the surroundings of the glaciated areas and highest periglacial environments, it is unlikely that permafrost existed in other areas.

\section{Present-day}

Temperature increase in Iberian mountains since the last decades of the XIX century has been quantified in about $1{ }^{\circ} \mathrm{C}$ (González-Trueba et al., 2008; Oliva and Gómez-Ortiz, 2012). The $0{ }^{\circ} \mathrm{C}$ isotherm lies today close to the top of the highest peaks in the Cantabrian Mountains $(2500 \mathrm{~m}$; González-Trueba et al., 2007) and Sierra Nevada (3400 m; Oliva et al., 2016b), which explains the inexistence of widespread permafrost conditions. In these massifs, the bottom of the northern cirques that held glaciers during the LIA encompasses buried ice and permafrost covered by debris left by paraglacial dynamics (Serrano et al., 2011b; Gómez-Ortiz et al., 2004; RuizFernández et al., 2016; Pisabarro et al. 2016). In the Veleta cirque, in Sierra Nevada, a rock glacier formed during post-LIA deglaciation shows multiple subsidence and collapses as a result of the accelerated melting of the frozen body existing in its interior (Gómez-Ortiz et al., 2014).

In the Pyrenees, BTS measurements, geophysical surveying and geomorphological observations made in several massifs indicate that mountain permafrost regime occurs today above $2630 \mathrm{~m}$ in northern aspects and $2800 \mathrm{~m}$ in southern ones (Serrano et al., 1999, 2001, 2002, 2006, 2009, 2011a; González-García et al., 2014). Possible permafrost conditions have been estimated above $2400 \mathrm{~m}$ in northern slopes and above $2650 \mathrm{~m}$ in southern ones, with high variability depending on the massifs. While possible permafrost in the Infierno massif is located above $2450 \mathrm{~m}$, in the Maladeta it exists above $2760 \mathrm{~m}$ and in the Posets above $2800 \mathrm{~m}$ (Serrano et al., 2001, 2009; González-García, 2014). The same variability is detected in the probable permafrost areas, located generally above $2700 \mathrm{~m}$, oscillating between $2630 \mathrm{~m}$ in north faces and above $2800 \mathrm{~m}$ in southern ones. While in the Infierno massif the probable permafrost lies above 2650, in the Maladeta it sits above $2890 \mathrm{~m}$ and in the Posets above $2950 \mathrm{~m}$. Three types of high mountain permafrost have 
been differentiated: (i) climatic origin, as suggested where MAAT are around $-1 /-2{ }^{\circ} \mathrm{C}$; (ii) topoclimatic, located in lower environments where cirque walls condition low incident radiation; and (iii) morphodynamic, where buried ice existing below the debris cover favours permafrost aggradation (González-García, 2014). In recently deglaciated environments there are landforms linked to frozen bodies, such as protalus lobes and frost mounds, as well as other, such as patterned ground features and solifluction lobes located always around 2700-3000 m, which may be also associated with permafrost (Serrano et al., 2000, 2001; Feuillet, 2010; Feuillet and Mercier, 2012; González-García, 2014; González-García et al., 2017).

Both in the Cantabrian Mountains (Gómez-Lende et al., 2014) and the Pyrenees (Bartolomé et al., 2015) there are also other landforms including subsurficial frozen features, which are an inheritance from the LIA. Ice caves show bedrock recording below freezing mean annual ground temperatures in contact with the perennial ice, and therefore may be defined as permafrost. In the case of the Cantabrian Mountains, the organic remnants trapped in the ice provided ages between 200 and 600 cal yr BP (Gómez-Lende, 2015), whereas in the Pyrenees ranged between 200 and 1200 cal yr BP (Bartolomé et al., 2015; Leunda et al., 2015; Sancho et al., 2016).

Figure 3

\subsection{Southern Alps}

The Southern Alps constitute the south side of the European Alps and include only the southern slope of the highest summit of the European Alps like the Monte Bianco (4810 m), Monte Rosa $(4634 \mathrm{~m}$ ) but also entirely some other peaks around $4000 \mathrm{~m}$ (like Gran Paradiso $4061 \mathrm{~m}$ or Ortles $3905 \mathrm{~m}$ ). The Southern Alps are crossed by large valleys mainly W-E oriented (Aosta Valley, Valtellina) or N-S (Ossola Valley, ValCamonica, Adige Valley; Piave Valley or Tagliamento Valley). The Southern Alps can be divided into four main sectors: the Southern sector or Maritime Alps located between Italy and France south of Maddalena Pass; the western sector located between Maddalena Pass and the Ossola Valley; the central sector between the Ossola Valley and Adige Valley and the Eastern sector eastward of Adige Valley. These sectors reflect different local climate and different prevailing lithologies.

The southern and western sectors are characterized mainly by prevailing metamorphic and crystalline rocks while in the eastern sector Mesozoic carbonates prevail. Within the central sector the southern areas are dominated by Mesozoic carbonates whereas the northern areas by metamorphic and crystalline rocks. The differences in climate of these sectors are mainly related to the variation in the precipitation regime that reflects the main orientation of the mountain belt. In general, the outer parts of the mountain belt (southern and the more eastern areas of the Eastern sector) are the wettest while the northern (and inner) areas of the central sector are the driest.

\section{Last Glaciation}

There is still considerable uncertainty about the timing of the last glacial stadials recorded in the Alpine end-moraines at about 18-21 ka cal BP before the onset of glacial termination (Ivy-Ochs et al., 2008), although the LGM culminations in the southern Alps may span from 26 to $21 \mathrm{ka}$ cal BP (Monegato et al., 2007, 2017; Ravazzi et al., 2012; Mozzi et al., 2013; Rossato et al., 2013; Federici et al., 2017). Paleo-temperatures between 30 and $17 \mathrm{ka}$ BP have been recently reconstructed in NE Italy through the analyses of chironomids of lacustrine sediments series (Lake della Costa, Samartin et al., 2016). These authors associated the lack of chironomids remains around $24 \mathrm{ka}$ and $18 \mathrm{ka}$ cal BP to very cold conditions correlated with Heinrich events (HE; Heinrich, 1988) HE-2 (24.2 $\pm 3.8 \mathrm{ka}$ cal BP) and HE-1 (16.9 $\pm 3.3 \mathrm{ka}$ cal BP) (Hemming, 2004). In these events possibly a weakening of the Mediterranean low-pressure systems occurred with a 
higher aridity in the Mediterranean (Tzedakis et al., 2004; Kwiecien et al., 2009). On the other hand, a southward shift of the storm track between 26.5-23.5 ka cal BP has also been suggested, together with a change in the seasonal distribution of precipitation, predominantly occurring between spring and autumn (Luetscher et al., 2015).

Evidence of active periglacial processes at low elevations as well as in the Po plain are almost unknown. Nevertheless, two stratified scree deposits have been described in the Maritime Alps (Pappalardo, 1999) with stratified screes, partially cemented, on the southern slopes of M. Cornizzolo (1242 m) and on M. Barro (923 m) very close to Lake Como. Possible cryoturbations on the loess cover at Bagaggera $(310 \mathrm{~m})$, only few $\mathrm{km}$ south of Lake Como, have also been detected (Guglielmin, unpublished data). An interesting indicator of periglacial or cryotic conditions during the Late Pleistocene and LGM is the distribution of loess. According to Cremaschi et al. (2015) between 70 and $35 \mathrm{ka}$ cal BP large loess deposits were deposited along the northern, western and southern margins of the Po plain. In the Julian Alps, between Italy and Slovenia, four rock glaciers have their front at $1076 \mathrm{~m}$ on average (Colucci et al., 2016a), which is very close to the estimated ELA during the LGM (1200 m, Colucci et al., 2014). This also suggests a temperature drop of at least 7.1-7.6 ${ }^{\circ} \mathrm{C}$, which is in accordance with LGM temperature reconstructions for this sector of the Alps (Kuhlemann et al., 2008).

The presence of relict block streams and blockfields is also reported (Figure 4), and the largest area covered by such features $\left(140 \mathrm{~km}^{2}\right)$ is the Ultramafic Lanzo Complex a short distance from Turin, at an elevation of 1000 to $1650 \mathrm{~m}$. These landforms could be related to permafrost conditions during the LGM (Fioraso and Spagnolo, 2009; Paro, 2011). Other block streams and blockfields are located in the internal margin of Piedmont between Sangone valley $(50 \mathrm{~km} \mathrm{~S}$ Turin) and Oropa (150 km NE of Turin) (Paro, 2011).

Figure 4

\section{Deglaciation}

The onset of glacial retreat in the southern Alps is thought to have occurred at $20.8 \pm 1.5 \mathrm{ka}$ (Gianotti et al., 2008), almost simultaneously with the Fennoscandinavian Ice Sheet (FIS) (A.L. Hughes et al., 2016). Downwasting of the large piedmont glaciers back into the Alpine valleys during the Late Glacial promoted widespread paraglacial activity, although several glacial readvances took place between the OD and the YD (Ivy-Ochs et al., 2008, 2009). Remnants of moraines of the YD glacier advance have been morphologically associated to rock glaciers from the lowermost belt (Frauenfeder et al., 2001; Ivy-Ochs et al., 2009).

Rock glaciers constitute widespread periglacial landforms in the southern Alps, both in the form of active and inactive landforms (Table 3). At present, climatic conditions favourable for their activity range between 2400 and $2900 \mathrm{~m}$ (Guglielmin and Smiraglia, 1997; Seppi et al., 2012; Scotti et al., 2013; Colucci et al., 2016a). Relict forms are generally 400-500 m lower than the active ones, corresponding to a temperature drop of ca. 2.6-3.3 ${ }^{\circ} \mathrm{C}$ (Frauenfelder et al., 2001). Also for this reason, despite the low number of dated rock glaciers in the southern Alps, YD or early Holocene ages have been suggested for most of them. The mean altitude of the front of the YD rock glaciers in the Alps is found at the lowest elevations in the SE fringe of this mountain range, with fronts distributed at $1777 \mathrm{~m}$ (Colucci et al., 2016a).

Table 3

In the SW Alps (France), more than 1000 relict rock glaciers have been identified by Bornet et al. (2014). The mean altitude of their fronts is around $2260 \mathrm{~m}$, whereas a few of them (7) reach 
altitudes lower than $1800 \mathrm{~m}$, with the lowest one lying at $1440 \mathrm{~m}$. It is probable that most of those relict rock glaciers are of YD age, though no absolute dating is yet available. A YD age is in good agreement with the general scheme of Late Glacial rock glaciers formation further North $\left(45^{\circ} \mathrm{N}\right)$ proposed by Cossart et al. (2010). Nevertheless, the authors emphasize the poor climatic significance of those permafrost-related landforms, because they developed at higher altitude than the local YD moraine and disconnected from talus slopes, therefore their extent has probably been limited by the availability of sediment sources. These conclusions are consistent with several geoelectrical resistivity soundings carried out on rock glaciers in different sectors, from the Col du Lautaret (near Briançon village) to the Mercantour area (data partly reviewed by Ribolini and Fabre, 2006). Overall, looking at the minimum altitude of the relict rock glacier fronts in the southern Alps (Guglielmin and Smiraglia, 1997; Seppi et al., 2012; Scotti et al., 2013; Bornet et al., 2014; Colucci et al., 2016a), there is a clear lowering trend from the western Alps (2260-2340 $\mathrm{m})$ to the central Alps $(2170-2281 \mathrm{~m})$ and the southeastern Alps (1778 m) (Figure 5). Although the Maritime Alps do not follow this scheme, this overall pattern in rock glacier elevations follows the ELA depression observed in the eastern Alps compared to the western Alps at the LGM peak (Kuhlemann et al., 2008).

Figure 5

\section{Holocene}

According to Finsinger and Tinner (2006), during the Early Holocene two cooling phases (8.87.3 and 6.1-5.2 ka cal BP) occurred in the western Alps. The cold event at 8.2 ka cal BP has also been documented in the eastern Alps with ca. $3^{\circ} \mathrm{C}$ below the early Holocene thermal maximum (Ilyashuk et al., 2011), which has been reconstructed between 9 and $5 \mathrm{ka}$ BP with an estimated mean July temperature $1-2^{\circ} \mathrm{C}$ warmer than the recent pre-industrial period (Samartin et al., 2017). Since $4.5 \mathrm{ka}$ BP, with the exception of the end of the 20th century, a progressive cooling trend occurred (Ilyashuk et al., 2011). During the Holocene glaciers showed several advance stages that were not synchronous within the Alps, although most of the glaciers at the onset of the Holocene recorded a rapid shrinkage to a size generally smaller than their late 20th century size until $3.3 \mathrm{ka}$ cal BP (Ivy-Ochs et al., 2009). Subsequently, glaciers showed a widespread re-advance especially between 3.0 and $2.6 \mathrm{ka}$ cal BP and between 1.4 and $1.2 \mathrm{ka}$ cal BP with the final major last readvance during the LIA between 0.45 and 0.1 ka cal BP (Ivy-Ochs et al., 2009).

With regards to the chronology of Holocene periglacial activity in the southern Alps, there are only a few available ages for periglacial and permafrost landforms. A cooler and dryer period ca. $4.5 \mathrm{ka}$ cal BP must have favoured permafrost aggradation and rock glaciers development in the southern Alps (Ilyashuk et al., 2011). The re-calibraton with OxCal 4.3.1 (Bronk Ramsey, 2009) of the available radiocarbon ages of inactive rock glaciers (Calderoni et al., 1998; Dramis et al., 2003 ) in the central and western Italian Alps using the IntCal 13 dataset, suggests that the period of maximum activity occurred between 2720 and 2850 cal yr BP with some older exceptions (all younger than $5900 \mathrm{cal} \mathrm{yr} \mathrm{BP).} \mathrm{On} \mathrm{the} \mathrm{other} \mathrm{hand,} \mathrm{based} \mathrm{on} \mathrm{the} \mathrm{existence} \mathrm{of} \mathrm{a} \mathrm{paleosoil} \mathrm{buried} \mathrm{by}$ the rock glacier front, Calderoni et al. (1998) and Scapozza et al. (2010) showed evidence of their activity between 929 and 1374 cal yr BP, a similar age to that reported by a Salix sp. leaf trapped within the ice of the Foscagno active rock glacier dated at 919-961 cal yr BP (Stenni et al., 2007). Recently, Krainer et al. (2015) found that the age of ice within an active rock glacier in the central Italian Alps ranged between 8960 and $2240 \mathrm{cal}$ yr BP at 23.5 and $2.8 \mathrm{~m}$ depth, respectively, showing evidence that the ice preserved within the rock glaciers can be useful paleoclimate archives. The investigation in fact shows that frozen material, which had existed during most of the Holocene, is now thawing; this is strong evidence that temperatures during the past about 9 ka have never been as high as they are today. 
Widespread wetter and cooler condition over the Alps promoted a well-documented glacier advance during the LIA ( 1400-1860 AD; Ivy-Ochs et al., 2009). After the LIA, the warming trend in the Alps has been about twice the global trend over the time period $1906-2005\left(1.4^{\circ} \mathrm{C}\right.$; Brunetti et al., 2009) and in the SE Alps temperature at $2200 \mathrm{~m}$ increased by about $1.7^{\circ} \mathrm{C}$ from 1851 to 2012 (Colucci and Guglielmin, 2015) leading to a $96 \%$ reduction in volume of glacial bodies (Colucci and Žebre, 2016). In the French western Maritime Alps, geophysical investigations provided resistivity values coherent with permafrost existence at about $2550 \mathrm{~m}$ in the Mercantour sector (Evin and Fabre, 1990). In the Ubaye-Queyras sector, rock glaciers below $2400 \mathrm{~m}$ lack internal ice, while above $2500 \mathrm{~m}$ permafrost starts to be common (e.g. Marinet rock glacier; Evin and Fabre, 1990; Evin et al., 1990; Assier et al., 1996; Smiraglia et al., 1996; Ribolini et al., 2010). This indicates that $2500 \mathrm{~m}$ represents here the modern limit for the existence of active rock glaciers. In the Lautaret and Mt. Viso areas, active rock glaciers were found at 24002450 m (Evin, 1991; Francou and Reynaud, 1992; Bodin et al., 2009). According to Bornet et al. (2014) more than 50\% of the active and inactive rock glaciers (following Barsch, 1996) in the SW French Alps, from a total number of 780 inventoried landforms, are located above $2600 \mathrm{~m}$ and $51 \%$ of them are lying on N and NW facing slopes. They cover $2 \%$ of the total surface $(50$ $\mathrm{km}^{2}$ ) and mostly develop between 2100 and $3000 \mathrm{~m}$. Most of the active rock glaciers in the southern French Alps are smaller than $0.1 \mathrm{~km}^{2}$, whereas the relict ones are generally larger (up to a few $\mathrm{km}^{2}$ ). More than $80 \%$ of the active and inactive rock glaciers are probably located below the regional mean annual $0^{\circ} \mathrm{C}$-isotherm, raising the question of their stability under climate change (Bodin et al., 2015). This probable imbalance with the present climatic conditions may be responsible for the fast flow observed on some very active rock glaciers (Delaloye et al., 2008), and may also have led to the collapse of the Bérard rock glacier during summer 2006 (Bodin et al., 2017).

In the western Italian Alps active rock glaciers reach with their fronts a mean elevation of 2647 $\mathrm{m}$ although a few active rock glaciers appear sporadically between $2000 \mathrm{~m}$ and $2300 \mathrm{~m}$. In the Central Italian Alps the mean elevation reached by the active rock glaciers is lower $(2526 \mathrm{~m})$ but ice was found within rock glaciers locally also at very low elevation in ventilated talus $(1000 \mathrm{~m}$; Guglielmin, unpublished data). As well known the lower altitudinal limit of permafrost based on the elevation of the active rock glaciers, although investigated through geophysical methods, can be not representative of the real regional permafrost; in fact, the lower limit can decrease up to $200 \mathrm{~m}$ due to the local density-driven air flows (Balch, 1900). Several rock glaciers have developed since the LIA in the Adamello-Presanella area (eastern Italian Alps) where the current mean elevation of the fronts of active rock glaciers is $2527 \mathrm{~m}$, around $400 \mathrm{~m}$ above the limit of the relict ones and where patches of sporadic permafrost can reach an elevation of $2200 \mathrm{~m}$ (Baroni et al., 2004). Only a few active rock glaciers occur in the western Alps within LIA deglaciated areas; this is the case of an active rock glacier in the Dolomites (SE Alps) at about $2400 \mathrm{~m}$ forming in an area previously occupied by the tongue of a LIA glacier and now dominated by periglacial processes. This study provides an example of how periglacial processes are replacing glacial processes under present climate change during the paraglacial stage (Seppi et al., 2014). Recently, possible sporadic permafrost in an area occupied by two protalus rampart have been deduced based on BTS measurements in the Carnic Prealps at $2258 \mathrm{~m}$ (Colucci et al., 2016a). Nine active protalus and pronival ramparts, located in front of permanent snow/firn bodies and ice patches, have been also reported in the Julian Alps and in the Kamnik-Savinja Alps at an average altitude of $2158 \mathrm{~m}$ (Colucci, 2016).

Although in the Alps permafrost is limited to the highest and driest areas, ground ice is also reported from several caves (Figure 6). Ice caves are generally widespread in high elevated karstic environments of the Alps, mainly in the central and eastern parts. The real distribution and size 
of ground ice in Alpine caves is still very uncertain, although recently in the southeastern Italian Alps 1100 ice caves have been reported. Here, they are generally located between 1500 and 2200 $\mathrm{m}$ and their distribution is well-correlated with MAAT and altitude, being significantly more frequent for MAAT lower than $2{ }^{\circ} \mathrm{C}$ and $5^{\circ} \mathrm{C}$; therefore, they are placed within the periglacial domain characterized by high precipitations (Colucci et al., 2016b). In Slovenia, 551 ice caves have been reported by Mihevc (2008). According to the Slovenian Cave Registry (2014), approximately 520 cryo caves, of which ca. 100 ice caves, can be found in the Slovenian Alps. Most of them have the entrance between 1000 and $2400 \mathrm{~m}$ (Mihevc, 2008). The radiocarbon age of an insect found in an ice core extracted in 2003 from the Abisso sul Margine dell'alto Bregai (central Alps) reported an age of $185 \pm 30 \mathrm{cal} \mathrm{yr}$ BP (Citterio et al., 2005). In the cave Ledena jama pri Planini Viševnik (eastern Alps), an ice core was recently extracted and larch trapped in the ice yielded a radiocarbon age of $300 \pm 45 \mathrm{cal}$ yr BP (Staut et al., 2016). In the light of accelerated climate change, other important paleoclimate archives exploitable from ice caves are represented by in-situ coarse cryogenic cave carbonates, recently discovered for the first time in a vertical ice outcrop of a cave in the southeastern Alps (Colucci et al., 2017).

Figure 6

\subsection{Italian Peninsula}

The Italian Peninsula lies between the Tyrrhenian Sea on the west, the Ionian Sea on the south, and the Adriatic Sea on the east. It includes large plains of northern Italy (Po Plain and Venetian Plain) and extends over more than $1200 \mathrm{~km}$ crossing $8^{\circ}$ of latitudes between 38 and $46^{\circ} \mathrm{N}$. The Apennine Mountains run along the entire peninsula and culminate in the Gran Sasso d'Italia (2912) and La Majella (2793 m). Geologically, the Apennines are quite homogeneous with a clear dominance of Mesozoic carbonates although sandstones, shales and flysch are also found, especially in the northern Apennines.

In the Italian Peninsula, from the Late Pliocene/Early Pleistocene transition the climate was characterized by rapid succession between xeric cool (glacials) and humid warm (interglacials) phases (Bertini, 2010). These alternating climatic conditions favoured the existence of "warm" steppes or coniferous forests alternated with subtropical to warm-temperate deciduous forests. During these periods, the paleogeography of the Italian coasts changed significantly due to sea level variations; indeed, the coastline of Adriatic Sea moved hundreds of km southward during the LGM and did not reach the current position until ca. 7 ka (Lambeck et al., 2011; Anzidei et al., 2014).

\section{Last Glaciation}

In the Apennines valley glaciers were only present on the highest mountains, with the maximum glacial expansion dated at $27.2 \pm 0.9 \mathrm{ka}$ cal BP in the Campo Imperatore valley and a rapid glacial retreat at around $21 \mathrm{ka} \mathrm{cal} \mathrm{BP} \mathrm{(Giraudi} \mathrm{and} \mathrm{Frezzotti,} \mathrm{1997).} \mathrm{Subsequently,} \mathrm{lake} \mathrm{level} \mathrm{oscillations}$ of Fucino Lake showed an aridity period between 20 and $17 \mathrm{ka} \mathrm{cal} \mathrm{BP}$ and between $15 \mathrm{ka} \mathrm{cal} \mathrm{BP}$ and the Early Holocene (Giraudi, 1998). More recently, at Campo Felice (central Apeninnes) Giraudi (2012) suggested that the maximum glacial advance was dated earlier than in other areas (33-27 ka cal BP) driven by a relatively milder and wetter period. Kuhlemann et al. (2008) modelled the air circulation and the ELA of the glaciers in the Mediterranean area indicating possible conditions for glaciers occurrence also on Mt. Pollino in Calabria and on Mt. Etna in Sicily.

Several landforms were related to periglacial or permafrost conditions during the LGM or during the deglaciation process, particularly during the OD in Italy (Figure 7). In the northern Apennines only a couple of relict rock glaciers described by Chelli and Tellini (2002) were associated to 
LGM period on the northern slopes of the highest mountains of this belt between Mt. Cusna (2121 $\mathrm{m})$ and Mt. Cimone $(2165 \mathrm{~m})$. Rock glaciers from this period are more frequent in the central Apennines, where 38 relict rock glaciers were identified by Giraudi (2002) almost all located along the eastern side of the central Apennines. They are mainly present on the Gran Sasso Massif (2912 m), the Maiella Massif (2793 m) and Mt. Velino (2486 m). In the southern Apennines only one relict rock glacier has been detected on the northern slope of Mt. Pollino (2267 m).

Figure 7

Block streams from this stage are located around Mt. Beigua $(1287 \mathrm{~m})$, few $\mathrm{km}$ far from the Ligurian Sea. These landforms are located between 900 and $1100 \mathrm{~m}$ on all the slopes and are characterized by an open-work texture in the upper $1.5 \mathrm{~m}$ thickness with angular or subangular blocks and frequent vertical dipping, or imbrication of the boulders (Firpo et al., 2006). Remarkably, none has any rock cliff or free face at their head and they show generally the smallest blocks in their frontal part. These landforms are all shaped on the same bedrock (serpentine and metabasalts) and they could have formed at a maximum age of $33 \mathrm{ka}$ (Firpo et al., 2006). Moreover, in the upper parts of the Mt. Beigua thors and blockfields are also present, suggesting intense periglacial conditions (Firpo et al., 2006).

In the Apennines stratified scree deposits (gréeze litée) are the most widespread and studied periglacial sedimentary archives (Table 4). They were found in different localities of the Northern Apennines, such as Corniglio and Bratica Valley (Chelli and Tellini, 2002), Monte Prampa (Bernini et al., 1978), Alpi Apuane (Federici, 1981) and, above all, in the central Apennines (Coltorti and Dramis, 1988; Coltorti et al., 1983) and in different valleys in the Marche region. In the central Apennines stratified screes were described in the late 1970's mainly along the Adriatic side of Umbria-Marche Apennines (Coltorti et al., 1979, Castiglioni et al., 1979; Boenzi, 1980), where these deposits are particularly widespread and connected with outcrops of limestone and marly limestone bedrock (Coltorti et al., 1983). These deposits are documented at different elevations from the coast to more than $2000 \mathrm{~m}$ (Mt. Conero) generally at the foot of rectified slopes or down-slope ancient nivation hollows. Features identified as stratified scree were also found southward in Abruzzo (Maielama valley; Frezzotti and Giraudi, 1992; Sulmona valley, Miccadei et al., 1999), Molise (Coltorti, 1983; Scarciglia, 2000) and Puglia regions (Boenzi et al., 1977). In some cases, they were also found close to the coast of the western side of the Apennines on the Palmaria Island, close to La Spezia (Chelli and Pappalardo, 2006) and on the Sorrento Peninsula (Brancaccio, 1968). The southernmost stratified screes were found in Calabria (Mt. Pollino and Mt. Sila down to $500 \mathrm{~m}$; Boenzi and Palmentola, 1975; Praia a Mare and Mormanno down to $700 \mathrm{~m}$; Robustelli and Scarciglia, 2006). In most of the cases, they were probably associated to seasonal frost conditions, with no permafrost regime.

Table 4

Finally, cryoturbations have been also documented on soils of Mt. Beigua at $650 \mathrm{~m}$ (Rellini et al., 2014) and at even lower elevations in the Cilento hills (at $30 \mathrm{~m}$ asl; Scarciglia et al., 2003) where severe winter frost was hypothesized during the Last Glaciation. Only in one case, in the Sila Mountain at $1350 \mathrm{~m}$, a fossil sand wedge, an ice wedge cast and some other cryogenic features within the soils were described by Dimase (2006).

\section{Holocene}

According to Giraudi et al. (2011), the onset of the Holocene in the Italian Peninsula and in Sicily was characterized by dramatic environmental and climatic changes. Between ca. 9.5 and ca. 6$5.5 \mathrm{ka}$ cal BP the climate was generally warmer and wetter than present, although in some records 
the wettest period seems to have occurred later at ca. 6-5 ka cal BP. Subsequently, a progressive cooling with higher precipitation variability started at $4.5 \mathrm{ka}$ cal BP, with wet periods recorded at 2.8-2.6, 1.4-1.2 and 0.5-0.3 ka cal BP and an aridity peak between 3.7 and $3.2 \mathrm{ka}$ cal BP (Calderoni et al., 1998; Giraudi, 1998). No dated evidence of glacial advances has been documented in the Italian Peninsula during the Holocene except for Gran Sasso area, where the Calderone glacier extends now over a few ha (Hughes et al., 2006a). Here, the glacier is thought to have persisted in this cirque throughout the Early Holocene, although the cirque was probably ice-free between ca. 4.3 and $3.9 \mathrm{ka}$ cal BP (Giraudi, 2004; Hughes, 2006a). Subsequently this glacier experienced several phases of expansion, namely at ca.: 2.9- 2.7, 1.4-1.3 and 0.64-0.58 ka cal BP (Giraudi, 2003, 2004; Hughes, 2006a).

The ages for periglacial landforms developed during the Holocene are rare and limited to few rock glaciers in the central-eastern Apennines. According to these ages, it is possible that permafrost existed during the Early Holocene at elevations higher than 1900-2000 m and started to degrade at ca. $7 \mathrm{ka}$ cal BP (Dramis et al., 2003). Nevertheless, a possible new phase of permafrost aggradation may have occurred at high elevations during the aridity phase that took place between 3.7 and $3.2 \mathrm{ka}$ cal BP (Dramis et al., 2003).

\section{LIA and present-day}

It is reasonable to hypothesize that colder conditions prevailing during the LIA favoured the development of some sporadic permafrost at elevations above $2200 \mathrm{~m}$ in the central Apennine (Mt. Gran Sasso, Maiella, Mt. Velino). A still active rock glacier is located on the north face of Mt. Amaro, with its front reaching $2522 \mathrm{~m}$ (Figure 8) (La Maiella massif, Dramis and Kotarba, 1992). As documented by BTS measurements, at elevations higher than $2400 \mathrm{~m}$ in the same massif (Bisci et al., 2003) and locally lower in Mt. Velino permafrost occurrence was possible, until at least 15 years ago (Guglielmin, unpublished data).

Figure 8

\subsection{Balkan Peninsula}

The Balkan Peninsula (also referred to as Balkans) is situated in south-eastern Europe and is bounded by the Adriatic, Ionian, Aegean and Black Seas. Situated between the Eurasian and African lithospheric plates, the Balkan Peninsula constitutes a mosaic of several mountain systems: Dinaric, Balkan, Macedonia-Rhodopes and Pindus, separated by internal tectonic depressions and major valleys. This internal topographic variability, coupled with general orientation of the mountain ranges, NNW to SSE Dinaric and Pindus and W to E for Bulgarian Mountains, generates a wide diversity of local geographical conditions, reflected in the presence and evolution of permafrost through time. The highest peak of the Balkans is Musala (2925 m), found in the Rila Mountain.

The geology of the Balkan Peninsula is very diverse. For instance, the Dinaric Alps are dominated by up to $8000 \mathrm{~m}$ thick Mesozoic carbonates (Jurasic limestone, Triasic dolomite and Werfen sandstones and schists, and Wengen sandstones). The Šar Mountains and Mount Korab on the eastern Albania border consist of polymetamorphic metasedimentary sequence with Hercynian granitoid intrusions in its central part. The major Bulgarian mountains are composed largely of Precambrian and Palaeozoic crystalline rocks (crystalline schist, gneiss, amphibolites, metamorphosed sedimentary rocks etc.) intruded by the Rila-West Rodophian batholith (Sinnyovsky, 2015), in some areas also by crystalline limestone and marble. In Greece the Pindus Mountains and Olympos Massif are dominated by Mezozoic (Lower Jurassic - Upper Cretaceous) 
sedimentary rock, especially limestone, dolomite and breccia, with ophiolithic rocks also present in some areas, such as at Mount Smolikas and Mount Vasilitsa.

The Balkan Peninsula is one of the Mediterranean regions where information on present and past permafrost conditions is very general and has a speculative character (King and Akermann, 1993; Dobiński, 2005). There is evidence that "isolated patches of permafrost" (Brown et al., 2001) are still present in the high mountain environment of the Balkan Peninsula. However, apart from ice caves (Bočić et al., 2014; Buzjak et al., 2014; Kern et al., 2006a) no other active permafrost features have been recognised in the study area. Relict permafrost features in the Balkan Peninsula have been recognised, although only recorded in detail in the Pindus, Prokletije, Rila and Pirin Mountains, where rock glacier inventories have been compiled (Palmentola et al., 1995; Hughes et al., 2003; Palmentola and Stamatopoulos, 2004; Dimitrov and Gikov, 2012; Gikov and Dimitrov, 2011; Magori et al., 2017). Sand wedges and cryoturbations present in the Pannonian Basin indicate a deep seasonal frost and perhaps isolated patches of sporadic permafrost (Ruszkiczay-Rüdiger and Kern, 2015) in the SW lowlands of the Pannonian Basin and in Getic Basin (Romanian Plain) (Frenzel et al., 1992) during the Pleistocene. However, there is no evidence of continuous permafrost as suggested by some previous studies (e.g., Poser, 1948; Velichko, 1982). At the LGM only the highest mountains of the Central Balkans were located in the discontinuous permafrost zone (Van Vliet-Lanoë and Hallegouët, 2001). Hence, it follows that rock glaciers are the main source of paleo-environmental information to infer past permafrost conditions in low-latitude areas of the Balkan Peninsula, while the ice caves are the best indicators for evaluating the present permafrost distribution in this area. Other elements of periglacial morphogenesis associated with permafrost conditions, such as large and medium size patterned ground and block streams, are very little-studied in the Balkan Peninsula. As is other parts of the Mediterranean region, thick Pleistocene stratified scree deposits are present across the Balkans especially in the uplands - and attest to active frost action under cold climate conditions. These sediments can be well preserved in limestone caves and rockshelters (e.g. Bailey and Woodward, 1997; Morley and Woodward, 2011), but establishing their paleoclimatic significance is not always straighforward (Woodward and Goldberg, 2001).

\section{Last Glaciation and Deglaciation}

The Last Glaciation in the Balkan Peninsula was characterised by the presence of ice fields and valley glaciers over some of the highest mountain massifs (e.g., Milivojević et al., 2008; Hughes et al., 2010, 2011; Kuhlemann et al., 2009, 2013; Žebre and Stepišnik, 2014; Sinnyovsky, 2015; Žebre et al., 2016). Late Pleistocene glaciers reached their maximum extents before the LGM in Pindus Mountains and this is recorded indirectly in the fluvial record downstream where glaciofluvial sediments have been dated at 25-30 ka (Lewin et al., 1991; Woodward et al. 1995; 2008; Hughes et al 2006b). In the Peloponnese, pre-LGM moraines have recently been dated to $30-40$ ka using ${ }^{36} \mathrm{Cl}$ exposure dating (Pope et al., 2017). In the Rila Mountains, Bulgaria, it is most likely that two glacial advances occurred, one at the beginning (25-23 ka) and one at the end (16$18 \mathrm{ka}$ ) of the global LGM (Kuhlemann et al., 2013). However, the exact timing of the local LGM over the Balkan Peninsula is still a matter of debate with some of the best evidence coming from the fluvial record in NW Greece (Woodward et al., 2008). In the Dinaric Alps, relatively high moisture (Hughes et al., 2010; Žebre and Stepišnik, 2014) was more favourable for glacier development in the highest massifs, meanwhile the lowlands were likely characterised by periglacial environment (Table 5). Almost no research on permafrost features from the Pleistocene period has been presented until now from this area. According to the interpretation by van Vliet-Lanoe et al. (2004) and Ruszkiczay-Rüdiger and Kern (2015), the Dinaric Alps area 
(at least its NW part) probably hosted discontinuous permafrost, bounded by a seasonal frost or even isolated patches of sporadic permafrost in the Pannonian basin to the NE. In fact, ice wedges and cryoturbations have been found in till in the Lovćen Mountain (Liedtke, 1962), supporting the idea of the permafrost presence in the Dinaric Alps. The presence of tors on the highest peaks indicates intensive periglacial processes in the ice-free areas above the local Equilibrium Line Altitude (ELA).

Table 5

In contrast, in the continental, more arid part of the Balkan Peninsula relict rock glaciers, and also block streams and patterned ground are widespread (Figure 9). Early periglacial studies from the Bulgarian mountains revealed a broad presence of scree deposits, block streams and blockfields (Stoyanov and Gachev, 2012). In addition, 27 and 55 rock glaciers were identified in Rila (Gikov and Dimitrov, 2011) and Pirin Mountains (Dimitrov and Gikov, 2012), respectively, though Magori et al. (2017) recently found new field evidence of the existence of 122 units in both massifs. Rock glaciers are distributed at elevations between 2080 and 2600 m, with a mean altitude of $2340 \mathrm{~m}$ in Rila Mountains and $2390 \mathrm{~m}$ in Pirin Mountains (Magori et al., 2017). They are considered to be from the end of Pleistocene and early Holocene (Dimitrov and Gikov, 2012; Gikov and Dimitrov, 2011; Kuhlemann et al., 2013), although the spatial relation between different altitudinal groups of landforms suggest other timing interpretation. In the Šar Mountains several rock glaciers, most of them in direct spatial connection with latero-frontal moraines, were recognized above $1700 \mathrm{~m}$ by Kuhlemann et al. (2009). Several generations of rock glaciers appear on the northern side of the ridge Bistra $(2651 \mathrm{~m})$ - Jezerski $(2604 \mathrm{~m})$ between 1750 and $2550 \mathrm{~m}$. A similar situation is found on the north and north-western slope of Mount Korab, where relict rock glaciers are present at altitudes between 1480 and $2600 \mathrm{~m}$. Relict rock glaciers are widespread also in the Pindus and other mountains in Greece. These features have been identified on Mount Parnassus (Pechoux, 1970) in central Greece, and Mount Tymphi (Hughes et al., 2003), Mount Smolikas (Hughes et al., 2006c) and Mount Lakmos-Peristeri (Palmentola and Stamatopoulos, 2004) in northwest Greece. The relict rock glaciers of the Pindus Mountains have wide-ranging elevations and occupy cirques between 1330 and 2300 m (Hughes et al., 2003; Palmentola and Stamatopoulos, 2004; Hughes et al., 2006a) and are likely to represent different generations of rock glacier. Hughes et al. (2003) argued that the rock glaciers of Mount Tymphi must belong to the LGM and formed as climate became colder and drier forcing cirque glaciers to retreat and become overwhelmed by debris. Further research is necessary to test the ages of the rock glaciers in the Balkans.

Figure 9

Besides rock glaciers other permafrost features can also be identified in the inland part of the Balkans (Figure 10). On the Vitosha Mountain, relict stone circles, tors and large blockfields were identified at the elevation range of 1850-1900 m. Some of the largest block streams in Europe, called Zlatnite Mostove (Golden Bridges) and Golyamata Gramada (Big Pile) are also present in this area. The first is $2.2 \mathrm{~km}$ long and $150 \mathrm{~m}$ wide, descending from 1800 to $1410 \mathrm{~m}$, and the latter $1 \mathrm{~km}$ long and $300 \mathrm{~m}$ wide at the altitude between 1900 and $1550 \mathrm{~m}$. Block streams are present in the Stara Planina (Balkan) Mountains, descending even down to $930 \mathrm{~m}$ in the northern slopes and $1130 \mathrm{~m}$ in the southern slopes. They can be found also in the granite part of Rila and Pirin Mountains where they descend down to $1500 \mathrm{~m}$, and in Osogovo Mountain, where they reach $1700 \mathrm{~m}$. Patterned ground and frost-shattered features were noted on Mount Tymphi by Hagedorn 
(1969) and Hughes (2004). Separating active or recent periglacial activity from Pleistocene features is difficult for many of the landforms on the highest mountains, although the lower periglacial forms must be Pleistocene in age.

It is certainly true that some rock glaciers form during deglaciation when glacier retreat causes glaciers to become overloaded by debris and morphing into ice-cored rock glaciers (Morris and Olyphant, 1990). It is also true that rock glaciers are most likely to form when climate is cold and dry (Haeberli, 1985). The period characterised by "deglaciation" depends on the timing of the local LGM. In many parts of the world this predates the global LGM, with cold and dry conditions at the global LGM causing glacier retreat (Hughes et al., 2013).

Figure 10

In the Pindus Mountains, on Mount Smolikas $(2632 \mathrm{~m})$, a rock glacier occurs at much higher altitude $(>2100 \mathrm{~m})$ than on neighbouring Mount Tymphi $(1800-2200 \mathrm{~m})$ (Table 6). This led Hughes et al. (2006a) to argue for a YD age for the Smolikas rock glacier. Based on climate modelling, Hughes et al. (2006a) argued that this feature and the associated last ever glaciers on Mount Smolikas could not be Holocene in age. On Mount Tymphi Late-glacial rock glaciers are absent because the level of permafrost was above the cirque floors and consequently, rock glaciers only formed on higher mountains such as Mount Smolikas. On Mount Lakmos-Peristeri, just 25 $\mathrm{km}$ southeast of Mount Tymphi, Palmentola and Stamatopoulos (2004) argued for an OD age for the numerous relict rock glaciers in the cirques of these mountains. This was based on earlier suggestions made for similar relict rock glaciers in the Prokletije Mountains, where the study of 16 inactive rock glaciers located above $1700 \mathrm{~m}$ was presented by Palmentola et al. (1995). Formation of several relict rock glaciers in the inland Dinaric Alps of Bosnia and Herzegovina and Montenegro (never studied before, but clearly recognized from different satellite images), indicating past permafrost conditions at elevations above $1650 \mathrm{~m}$, may also be related to one of the dry and cold periods of the late Pleistocene. This is in accordance with the recently compiled rock glacier inventory in the nearby SE Alps (Colucci et al., 2016a) where the formation of rock glaciers was related to the YD cold phase. However, in Greece Hughes et al. (2003) argued that similar elevation rock glaciers were older, forming during the LGM. The OD ELA in Šar Mountains was calculated to 2200-2350 m (Kuhlemann et al., 2009). Thus, it is likely that rock glaciers present in the altitudinal belt 1950-2060 m on the northern side of the ridge Bistra (2651 $\mathrm{m})$ - Jezerski (2604 $\mathrm{m}$ ) belong to this period. During YD, the ELA was placed at 2300-2400, so the rock glacier at 2260-2550 m could belong to this period. Relict rock glaciers on Mount Korab located above $2400 \mathrm{~m}$ appear to be fresher (without vegetation) and could belong also to one of these two periods. In the Rila Mountains, rock glaciers above $2200 \mathrm{~m}$ and below local ELA are likely to be formed in the deglaciation period. During the deglaciation period, the stadial moraines at $1700 \mathrm{~m}, 1850 \mathrm{~m}$, and $2000 \mathrm{~m}$ point to gradual retreat of the glaciers in the Osogovo Mountain (Milevski, 2008). Embryonic rock glaciers at 1850 and $2030 \mathrm{~m}$ in the cirque below the Ruen Peak (2251 m) were likely active during this period. However, none of the rock glaciers in the Balkans have been dated and therefore the competing geochronological hypotheses proposed by Palmentola et al. (1995), Hughes et al. (2003) and Palmentola and Stamatopoulos (2004) remain to be tested.

Table 6

Holocene 
Holocene cooling periods in $8.2 \mathrm{ka}$ cal BP (Tonkov et al., 2016), $7.5 \mathrm{ka}$ cal BP (Stefanova et al., 2006) and between 6.7 and $5 \mathrm{ka}$ cal BP (Bozilova and Tonkov, 2000) based on pollen records were reported for the Rila and Pirin Mountains. It is likely that these cooling events triggered the formation of some newly rock glaciers, while the highest lying rock glaciers continued their existence. Rock glaciers in the Rila and Pirin Mountains situated above $2500 \mathrm{~m}$ were probably active also during Holocene. One example is the rock glacier on the northern slope of Polezhan Peak $(2851 \mathrm{~m})$ with the front at $2490 \mathrm{~m}$ where at least three rock glacier generations can be recognised. Also in the Šar Mountains, on the northern slopes of the Bistra (2651 m) - Jezerski (2604 m) ridge, rock glaciers above $\sim 2300 \mathrm{~m}$ likely persisted in their active mode during the Holocene, as suggested by Kuhlemann et al. (2009).

Some of the cirque and valley glaciers that were present during the YD likely persisted to Holocene in some areas of the Balkans. Calcite cements in cirque moraines, which provide minimum ages for the moraines, yield early Holocene ages in central Montenegro (Hughes et al., 2011). On Mount Olympus, in the north-facing cirque of Megali Kazania, large moraines were considered to be Holocene Neo-glacial moraines by Smith et al. (1997). This possibility has recently been advocated by Styllas et al. (2015). This would seem plausible given the presence of small glaciers today further north in the Balkans. It is possible that this was also the case in other inland mountains in the Balkan Peninsula, although there is very little known about the Holocene glacial history. Periglacial forms related to these small glaciers, such as nivation hollows, are also poorly understood. However, given the warmer conditions at the Holocene optimum it is arguable that smaller glaciers and snow patches nowadays present in Pirin, Prokletije and Durmitor Mountains (Gachev et al., 2016) would have been less than today.

\section{LIA}

Owing to cooling conditions during the LIA there were numerous small cirque glaciers (Hughes, 2010) in the highest massifs of the Balkan Peninsula. There would have also been many more perennial snow fields. Nival processes would have therefore been a significant geomorphological agent across the mountains in the Balkan Peninsula at this time. Rock glaciers above $2350 \mathrm{~m}$ in the Rila and Pirin Mountains probably reactivated during the LIA period.

\section{Present-day}

Because of relatively low altitude and low latitude, the mountain permafrost in the Balkan Peninsula is nearly inexistent in recent climate. Permafrost may be present in some niche localities on the highest peaks, and this possibility was highlighted in Dobinski (2005) who suggested that permafrost conditions may exist above $\sim 2700 \mathrm{~m}$ on Mount Olympus (2912 m), and above $\sim 2350$ $\mathrm{m}$ on Rila Mountain (2925 m). This idea is partially supported by Brown et al. (2001) modelling results, suggesting that sporadic permafrost is present only in the highest peaks of the southern Dinaric Alps, Šar Mountains, and Rila and Pirin Mountains. In fact, Milivojević et al. (2008) mapped two active rock glaciers in the central Prokletije Mountains. According to Hughes (2009) these features may not be actively moving because they lack the clear lobate form. However, they may be described as patches of sporadic permafrost. Perennial snow fields and modern nival forms are widespread across the highest mountains of the Balkan Peninsula. For example, Styllas et al. (2016) reported perennial snow and ice masses in the north-facing cirque of Megali Kazania (Olympus Mountain). Apart from this 16 glacierets and small cirque glaciers exist in the Durmitor, Prokletije and Pirin Mountains (Hughes, 2008; Djurović, 2013; Milivojević et al., 2008; Hughes, 2009; Gachev and Stoyanov, 2012; Gachev et al., 2016). Some of these ice masses are debris-covered and exhibit similar geomorphology to the buried ice patches of the Corral 
Veleta site in the Sierra Nevada, Spain (Gómez-Ortiz et al., 2001). Therefore, the possible presence of patches of sporadic permafrost below these perennial snow patches can not be excluded.

Instead ice caves are permafrost phenomena in carbonate massifs of the Balkan Peninsula which often exist at elevations where outside MAAT is well above $0{ }^{\circ} \mathrm{C}$ (Colucci et al., 2016b) owing to karstic topography which functions as cold air trap and thus promote the survival of permanent snow and ice. Majority of caves containing permanent frozen materials, the so-called cryo caves (sensu Colucci et al., 2016b), occur at elevations above 800-1000 $\mathrm{m}$ in the Dinaric Alps (Bočić et al., 2014; Kern et al., 2006b; Zupan Hajna, 2016) and mountains in Macedonia (Temovski, 2016), although some cryo caves in Slovenia were reported from lower altitudes (Mihevc, 2008). In the Dinaric karst of Slovenia about 100 cryo caves (Slovenian Cave Registry, 2014) and in the northern Velebit Mountain in Croatia 150 cryo caves (Buzjak et al., 2016) were explored by speleologists. Moreover, active patterned ground likely related to seasonal frost heaving was reported from some Slovenian caves by Zupan Hajna (2007), Miheve (2009) and Obu et al. (2018).

Nevertheless, periglacial activity is a significant geomorphological agent in the highest areas of the Balkan Peninsula. In the Rila and Pirin Mountains, periglacial processes are active above 1900-2000 m (Stoyanov and Gachev, 2012).

\subsection{Anatolian Peninsula}

Located between one of the world's most seismically active areas, the Anatolian Peninsula constitutes a relatively small orogenic plateau that is bounded by the Mediterranean, Aegean, Marmara and Black Seas. Despite its modest average elevations just $\sim 1200 \mathrm{~m}$ and low overall exhumation, the Anatolian Peninsula is a first-order morphotectonic feature that has fundamentally impacted the geologic, geomorphic, and climatic evolution of the Eastern Mediterranean (Ciner et al., 2013). The tectonically active boundaries of the plateau delineate the Anatolian plate, which has been extruding toward the west with respect to Eurasia since the Miocene as the result of extension in the Aegean and the Arabia-Eurasia collision (Şengör and Yilmaz, 1981; Bozkurt, 2001). The Eastern Black Sea Mountains (also known as the Pontides) and the Taurus Mountain Range bound the northern and southern flanks of the plateau respectively and attain elevations more than $3000 \mathrm{~m}$ in places. Several paleoglacial valleys with moraines, occasional small glaciers and periglacial features are preserved in these mountains (Palgrave, 1872; Luis, 1944; Kurter, 1991; Çiner, 2003; Sarıkaya et al., 2011; Çalışkan et al., 2012; Sarıkaya and Tekeli, 2012; Bayrakdar et al., 2015; Yavaşli et al., 2015). In the central parts, high volcanoes such as Ağrı (also known as Ararat, 5137 m), Süphan (4058 m) and Erciyes (3917 m) also contain active glaciers and periglacial features (Penther, 1905; Erinç, 1951; Messerli, 1964; Kurter, 1991; Kesici, 2005; Sarikaya et al., 2009; Sarıkaya, 2012).

The geology of the Anatolia Peninsula is rather complicated. However, the Taurus Mountains along the Mediterranean coast of Turkey are mainly made up of platform carbonate rocks with occasional presence of ophiolitic rocks emplaced as trust sheets (Monod, 1977). On the other hand, the Eastern Black Sea Mountains along the NE Black Sea coast of Turkey contain mostly quartz bearing lithologies composed of plutonic and volcanic rocks. The volcanoes scattered in the central parts of Anatolian Peninsula are generally andesitic to rhyolitic in composition. 
Late Pleistocene glacial deposits in Turkey are now well described and constitute one of the bestdated records of its kind in the world (Hughes and Woodward, 2017) (see a review of glacial landforms and TCN dating chronologies by Sarıkaya and Çiner, 2015, 2017). On the other hand, periglacial landforms are only scarcely described, often in local journals and in Turkish and lack quantitative age results. Here, we present an overview of the distribution of mountains with periglacial landforms based mainly on literature but also on field observations on periglacial processes and landforms formed since the Last Glaciation (Table 7).

Table 7

\section{Last Glaciation}

There are no age data on the periglacial landforms related to the Last Glaciation in Turkey. However, moraines in the Taurus Range, particularly in Mt. Sandiras (2295 m) (Sarıkaya et al., 2008), Mt. Akdağ (3016 m) (Sarıkaya et al., 2014), Mt. Dedegöl (2992 m) (Zahno et al., 2009; Çı1 ğın, 2015; Köse et al., 2017), Mt. Aladağlar (3756 m) (Zreda et al., 2011), Mt. Bolkar (3524 m) (Çiner and Sarıkaya, 2017) and Mt. Geyikdağ (2877 m) (Çiner et al., 2015, 2017; Sarıkaya et al., 2017) yield TCN ages that vary between $\sim 50$ to $5 \mathrm{ka}$. To the NW of Turkey, on Başyayla Valley of Mt. Kaçkar, (3937 m) along the Eastern Black Sea Mountain Range, the MIE is reported to be around $56 \mathrm{ka}$ (Reber et al., 2014). It is therefore reasonable to assume that the extent of glacier advances and retreats also controlled the intensity of periglacial activity as well as the development of periglacial landforms in these areas.

The synchronicity of the LGM in the eastern Mediterranean region is under current debate (e.g., Clark et al., 2009; Hughes and Woodward, 2008; Hughes et al., 2013). However, there seems to be a consensus on the rather synchronous LGM extent and timing (centred to around $21 \mathrm{ka}$ ) on the Taurus Mountains (e.g., Sarıkaya and Çiner, 2017), Eastern Black Sea Mountains (Akçar et al., 2007, 2008), Lesser Caucasus Mountains (Dede et al., 2017) and the individual mountains in the central Anatolia such as Mt. Uludağ (2543 m) (Akçar et al., 2014, 2017; Zahno et al., 2010) and Mt. Erciyes (Sarikaya et al., 2009). It is therefore very likely that during the Last Glaciation and at LGM, periglacial processes below LGM snowline, approximately between 2400-2600 m in the Taurus Mountains and 2300-2500 m in the Eastern Black Sea Mountains (Erinç, 1952; Messerli, 1967; Çiner, 2004), were active and permafrost mainly controlled the development of some relict rock glaciers as well as patterned ground features (Figure 11).

Figure 11

\section{Deglaciation}

Following the LGM, at around $21 \mathrm{ka}$ a rapid deglaciation is documented throughout the Anatolia Peninsula (e.g., Sarıkaya and Çiner, 2015). As in other periglacial alpine environments (Barsch, 1992; Knight and Harrison, 2008), mountains in Anatolia also experienced increasing rockfall and mass movements, leading to rock glacier instability, formation of outwash plains and sediment release to the rivers. This deglaciation was interrupted by two cold intervals; OD, which was rather long compared to the relatively shorter YD, where glaciers regained momentum and descended down valleys (Çiner et al., 2015; Sarıkaya and Çiner, 2015). These two cold stages were followed by rock glacier development, especially in the Eastern Black Sea Mountains (e.g., Akçar et al., 2007) and in Mt. Mercan (also known as Mt. Munzur; 3463 m) in central Anatolia (Bilgin, 1972). A relict rock glacier terminus that lies around $2100 \mathrm{~m}$ was recently TCN dated to 
$15.7 \pm 1.3 \mathrm{ka}$ in the Mt. Karçal (3932 m) of the Lesser Caucasus Mountains (Dede et al., 2017) (Figure 12).

Figure 12

\section{Holocene}

The Holocene record of periglacial conditions is not well known in Turkey. Although the existence of glaciers in southeastern Taurus Mountains (e.g., Mt Cilo, 4135 m) (İzbıkak, 1951; Erinç, 1953) and high volcanoes such as Mt. Ararat are known (Sarıkaya, 2012), only few glacial deposits were TCN dated. For instance, on the Erciyes Volcano in central Anatolia, reported Early Holocene $(9.3 \pm 0.5 \mathrm{ka})$ and Late Holocene $(3.8 \pm 0.4 \mathrm{ka})$ glacial advances suggesting also periglacial conditions surrounding this mountain (Sar1kaya et al., 2009). On the other hand, rock glaciers probably were extensively developed during the Holocene especially in the northern parts of the Anatolia Peninsula. However, the development of rock glaciers is rather restricted in the Taurus Range probably because of the well-developed karst that restrained surface water flow. Nevertheless, rock glaciers were previously described in Mt. Geyikdağ in the central Taurus Mountains (Arpat and Özgül, 1972; Çiner et al., 1999) and recently Çiner et al. (2017) TCN dated a rock glacier to $<6 \mathrm{ka}$ (Fig. 2c). On the other hand, a study carried out on the southern slopes of Mt. Ararat (Avc1, 2007) claimed that during the glacial/periglacial climates of the past, mass movements gave rise to debris on the slopes and blocky colluvium in the valley floor.

\section{LIA}

With the exception of Mt. Ararat ice cap that covers around $5.6 \mathrm{~km}^{2}$ (Sarikaya, 2012) and Mt. Cilo Uludoruk glacier $(<3 \mathrm{~km}$ long), only few small glaciers are present today in Turkey, where two third are located in the southeastern Taurus Mountains (Kurter, 1991; Çiner, 2004; Akçar and Schlüchter, 2005; Sarıkaya and Tekeli, 2014). However, glaciers were more numerous and much larger during the LIA in Turkey and in the Mediterranean mountains in general (Hughes, 2014, 2017).

For instance, the highest moraines in Mt. Uludağ were attributed to LIA (Erinç, 1952). More recently Zahno et al. (2010) TCN dated a boulder from the innermost moraine (sample TRU-12 in Zahno et al., 2010) with negligible cosmogenic nuclide concentration supporting a probable LIA advance in Mt Uludağ. Birman (1968) also tentatively proposed a recent age for the formation of this moraine.

In Mt. Aladağlar in the central Taurus Mountains a small glacier covered by rock debris (Altın, 2006; Gürgen et al., 2010) is probably a remnant of LIA glacier development. Even though at least 12 glaciers exist in the Eastern Black Sea Mountains, moraines associated with a LIA advance are reported to be absent in Kavron and Verçenik valleys of Mt. Kaçkar probably because of dry and cold climatic conditions (Doğu et al., 1993; Akçar et al., 2007, 2008; Bayrakdar and Özdemir, 2010; Reber et al., 2014). We can therefore presume that periglacial conditions surrounding these glacial environments were more extensive during LIA compared to today's conditions in these areas with probable development of rock glaciers and protalus lobes.

\section{Present-day}

Although no active glaciers exist in Mt. Uludağ in western Turkey, it is probably one of the bestdescribed mountains concerning periglacial landforms. Studies carried out by Erinç $(1949,1957)$ identified two distinct periglacial levels on Mt. Uludağ. The first one lies between 1900-2300 m 
and is characterised by garland soils that developed in slopes ranging between 2 and $40^{\circ}$. The second level lies above $2300 \mathrm{~m}$ and is mainly represented by stone accumulations, $40-50 \mathrm{~cm}$ in diameter, stone stripes and stone circles preserved over quasi-flat $\left(0-10^{\circ}\right)$ surfaces (Figure 12) (Öztürk, 2012). Additionally, Türkeş and Öztürk $(2008,2011)$ indicated that while several alpine plant species are effective in the formation of garlands, only two types of Festuca sp. are effective in the formation of circles. Although much less developed compared to Mt. Uludağ, Bilgin (1960) also reported garland soils at the summit and NE facing slopes of Mt. Kazdağ $(\sim 1700 \mathrm{~m})$, in the westernmost part of the Anatolia Peninsula, near the Aegean Sea. This mountain composed of granite and schist was too low to be glaciated during the Last Glaciation but relict block streams were encountered at $1350 \mathrm{~m}$ facing northeast suggesting past permafrost conditions (Bilgin, 1960).

Mt. Ilgaz in central Anatolia also shows some periglacial features (Erinç et al., 1961). While large features such as block flows and cyroplanation surfaces are classified as inactive, smaller stone circles $(50 \mathrm{~cm}$ in diameter) and garlands are thought to be active. Garlands and polygonal soils above $2500 \mathrm{~m}$ near Yedigöller Lake on the north-facing slopes of Mt. Esence (also known as Mt. Keşiş; $3549 \mathrm{~m}$ ) are present (Akkan and Tuncel, 1993). Stone rings at $2650 \mathrm{~m}$ on Mt. Mescid (3239 m) are also reported (Atalay, 1983).

On the Eastern Black Sea Range at Mt. Karagöl (3107 m), stone circles ranging from $25 \mathrm{~cm}$ to 1 $\mathrm{m}$ in diameter and ovoid depressions 1 to $1.5 \mathrm{~m}$ in diameter and few decimetres in depth are reported at ca. 1800 and $1900 \mathrm{~m}$, respectively (de Planhol and Bilgin, 1964). Turoğlu (2009) also reported recent solifluction, frost creep and mass movements such as rock falls, talus, talus creeps, rock avalanches and rock flows on the same mountain. In the nearby Mt. Karadag $(3331 \mathrm{~m})$ periglacial features are also known to exist (Bilgin, 1969; Gürgen, 2001). On Elevit and Hacivanak glacial valleys of Mt. Göller (3328 m) active garlands, stone circles and solifluction terraces related to seasonal frost conditions are best observed on the south facing slopes (Çiçek et al., 2006).

Active rock glaciers are mostly concentrated on the northeastern Turkey and central Anatolia. In a recent study, Gorbunov (2012) detected several active, inactive and fossil rock glaciers in Turkey using satellite imagery. Among around 600 rock glaciers located mainly between 2800$3400 \mathrm{~m}$, of which about 200 are reported to be active, with some reaching 1200-1300 m in length. In some places, fossil rock glaciers descend downvalleys to 2200-2300 m. For instance, in the upper parts of the northern tributary of the Başyayla Valley in the Eastern Black Sea Mountains and in the Mt. Karçal in the Lesser Caucasus Mountains several active rock glaciers were reported (Çalışkan, 2016; Gürgen and Yeşilyurt, 2012; Reber et al., 2014; Dede et al., 2015). In Kavron Valley intensive rock glacier activity is responsible for the destruction of LIA moraines (Akçar and Schlüchter, 2005). In the so-called ski valley of Erciyes Volcano a rock glacier is also described as being active (Sarkaya et al., 2003; Ünal and Sarıaya, 2013) (Figure 12b). On the other hand, according to Yeşilyurt and Doğan (2010) several debris-covered glaciers were mistakenly interpreted as rock glaciers on Mt. Munzur.

Mt. Dedegöl is the only site in western Taurus Mountains where rock glaciers are developed (Dellanoy and Maire, 1983). Although some are not active, others situated between 2500 and $2800 \mathrm{~m}$ are active with calcareous blocks of 0.5 to $1.5 \mathrm{~m}$ in diameter. In Mt. Aladağlar in the central Taurus Mountains, speleologists discovered a karstic cave at $\sim 3400 \mathrm{~m}$, containing $120 \mathrm{~m}$ thick ice along a shaft that was probably inherited from LIA (Bayan et al., 2003; Klimchouk et 
al., 2006) (Figure 12). This is the only known ice occurrence within a cave system in Turkey. On the Yedigöller plateau of Mt. Aladağlar where the paleo-ice cap is known to have melted at the onset of the Holocene (Zreda et al., 2011), stone stripes are also reported at $3200 \mathrm{~m}$ (Figure 12). Rock glaciers also developed in front of the rapidly melting glaciers of Mt. İhtiyar Şahap (also known as Mt. Kavuşşahap; 3650 m) on the southeastern Taurus Mountains (Doğu, 2009; Yeșilyurt et al., 2018).

\subsection{Northern Africa}

Northern Africa mountainous regions are dominated by the Atlas, a series of ranges and plateaus, running eastwards from the Atlantic at ca. $31^{\circ} \mathrm{N}$ in coastal Morocco to $35^{\circ} \mathrm{N}$ in the Mediterranean in northern Tunisia, across almost $2000 \mathrm{~km}$. In Morocco, the Atlas is divided in the Middle Atlas (Djebel Bou Naceur, $3340 \mathrm{~m}$ ), the High Atlas (Djebel Toubkal, $4167 \mathrm{~m}$ ) and the Anti-Atlas (Djebel Sirwa, $3304 \mathrm{~m}$ ), not analysed in this paper. The three major massifs in the High Atlas are, from west to east, the Djebel Toubkal massif $(4167 \mathrm{~m})$, the Irhil M'Goun massif $(4071 \mathrm{~m})$ and the Djebel Ayachi $(3751 \mathrm{~m})$. Towards the east, the High Atlas extends to the Saharian Atlas, culminating in the Aurès Massif in Algeria at $35^{\circ} \mathrm{N}(2324 \mathrm{~m})$. North of the Atlas and close to the Mediterranean coast, lie the Rif (3445 m) and the Algerian Tell (2308 m) divided from the former by the Algerian high plateaus (1729 m). Further south, already in the interior Sahara Desert, lie two other large massifs, with a drier climate and with evidence of relict periglacial phenomena: the Hoggar $(2981 \mathrm{~m})$ in southern Algeria at $23^{\circ} \mathrm{N}$, and the Tibesti $(3445 \mathrm{~m})$ in northern Chad at $21^{\circ} \mathrm{N}$.

The major geological structures of the mountains in North Africa are fold-thrust belts formed by the collision between the African and the European plates (Gómez et al., 1977; Dewey et. al., 1989) along the plate boundary. The materials in the Rif-Tell Atlas are allochthonous, with the presence of flysch sequences and limestones covering African shield metamorphics and granitoids. The High Atlas - Saharan Atlas is an intracontinental fold-thrust belt in the foreland of the Rif (Arboleya et al., 2004), with autochthonous rocks. Mesozoic limestones prevail in the Middle Atlas, also with Cenozoic basaltic lava flows infilling pre-existing valleys (Arboleya et al., 2004). The High Atlas has three major morphostructures, with the western part showing limestone plateaus, the central zone showing Paleozoic magmatics from the African shield (granites, rhyolites, andesites and trachytes) and the eastern zone, a folded structure of carbonates (Joly, 1962; Hughes et al., 2004). The Saharan Atlas is composed by folded structures affecting mostly Cenozoic limestones.

The Hoggar massif is located in a cratonic setting, showing in its western part, middle-Proterozoic thick meta-sedimentary units and alkaline-peralkaline intrusives, magmatic complexes of basic to ultrabasic rocks and volcanoclastic deposits, andesites to dacites and calc-alkaline batholiths. The central Hoggar is mainly composed of gneisses and schist belts, while the eastern Hoggar shows mainly gneisses and granites (Bertrand and Kaby, 1978). The Tibesti massif is composed of Precambrian crystalline rocks, being formed by a core of intrusive and metamorphic rocks, which is bounded by Paleozoic and sedimentary sequences. These units are partially capped by Tertiary volcanics (Ghuma and Rogers, 1978, Permentier and Oppenheimer, 2007).

The mountains of North Africa mark strong climatic gradients between the Atlantic in the west, the Mediterranean in the north, and the Sahara influence in the south. This impacts essentially the precipitation amounts, varying from over 2,000 $\mathrm{mm}$ in the Rif mountains to $145 \mathrm{~mm}$ in the Hoggar and $11 \mathrm{~mm}$ in the Tibesti, and are characterized by regimes, from the Mediterranean type, in the north, to semi-arid and arid regimes as one moves towards the Sahara. Air temperatures show both the effects of continentality and latitude, with striking impacts on the estimated altitudes of 
the $0{ }^{\circ} \mathrm{C}$ MAAT, which range from slightly above $3000 \mathrm{~m}$ in the Rif to about $4900 \mathrm{~m}$ in the Hoggar, much higher than the maximum elevations in these ranges (Table 2).

Periglacial features in North African mountains have been described by several authors, but most through a classical naturalistic approach, lacking quantification, sedimentological studies and absolute dating of relict features (Table 8). Most features relate to evidence of frost shattering, talus slopes, stratified slope deposits and more sporadically, to rock glaciers, although lacking detailed observations. At least one case of the latter, in the High Atlas, has been recently reinterpreted as a catastrophic rock slope failure deposit, rather than as a rock glacier (Hughes et al., 2014), which calls for a need for encompassing detailed studies and reinterpretation. Presentday periglacial activity has been vaguely described by the presence of solifluction landforms and ground frost features at high altitude localities, but again the observations lack modern objective assessments and monitoring data are lacking almost everywhere. A recent study by Vieira et al. (2017) based on geomorphological evidence and ground surface temperature data indicates the possible presence of permafrost in the upper reaches of the High Atlas. Both relict and presentday periglacial features reflect the climatic gradient, with the evidence showing an increasing moisture content from SE to NW and a decrease of temperatures.

Table 8

\section{Last Glaciation}

No absolute age records exist from periglacial deposits or landforms in North Africa and the only chronological framework for the cold event derives from glacial evidence, which have been especially well-studied in the High Atlas (De Martonne, 1924; Dresch, 1949; Wiche, 1953; Messerli, 1967; Messerli and Winiger, 1992; Chardon and Riser, 1981; Hughes et al., 2004, 2011, 2018; Hannah et al., 2017). In the Djebel Toubkal region, Hughes et al. (2018) have identified three phases of glacier advance or sustained stabilisation, with ages of ca. $50 \mathrm{ka}, 22 \mathrm{ka}$ and $12 \mathrm{ka}$, pointing to a pre-LGM maximum and to the presence of glaciers during both the LGM and the YD. These relate to several valley glaciers that descended in some areas down to $1900 \mathrm{~m}$, with typical glacier lengths of 2 to $9 \mathrm{~km}$. Other ranges showing glacier evidence are the Rif (Mensching, 1960) and the Middle Atlas (Dresch and Raynal, 1953; Raynal et al., 1956; Awad, 1963) in Morocco, and the Tell Atlas (Barbier and Cailleux, 1950) and the Aurès mountains (Ballais, 1981) in Algeria, but with no known absolute age records.

Relict periglacial deposits in northern Africa mountains have been attributed by the different authors mostly to the Last Glaciation (Figure 13). The most frequent reference to periglacial features are probably slope deposits, which vary from head-type deposits to stratified slope deposits and grèzes in some limestone areas. They were identified in the Algerian Tell above 1400 $\mathrm{m}$ and in the Aurés Massif above $1800 \mathrm{~m}$ (Tihay, 1973), and are widespread in the High Atlas (Chardon and Riser, 1981). We have observed a good outcrop at the Middle Atlas southeast of the Djebel Bou Iblane at $2350 \mathrm{~m}$. Other references to slope processes relate essentially to a diffuse concept of solifluction, which has to be accounted for with great care due to the difficulty relating to the identification of processes, but also to the variability of the interpretation of the concept. As such, relict solifluction features have been identified in the High and Middle Atlas (Awad, 1963) and Messerli (1973) associates frost action in the Hoggar and Tibesti to the presence of slope deposits and filling of hollows, which are present even below $2000 \mathrm{~m}$. Nivation forms (presumably hollows), as a set of geomorphic processes, have been identified by Messerli (1973) in the Hoggar (above $2400 \mathrm{~m}$ ), in the Tibesti (above $3000 \mathrm{~m}$ ), by Tihay (1973) in the Aurés above $1800 \mathrm{~m}$ and in the Algerian Tell above $1500 \mathrm{~m}$, by Marre and Quinif (1981) in the Algerian High Plateaux above $1500 \mathrm{~m}$, and in the Rif by Mensching (1960). Rock glaciers, which are the single landform identified which is an indicator of the presence of permafrost, have been reported for 
the Algerian Tell (possible) above $1100 \mathrm{~m}$ by Tihay (1973) (an altitude that seems excessively low), for the Middle Atlas between 2100 and $2500 \mathrm{~m}$ (Awad, 1963) and for the Rif by Mensching (1960). Nivation forms would have been widespread marginal to glaciated areas of the High Atlas during the Last Glaciation. Patterned ground can be observed on plateau surfaces in the High Atlas, especially between 3000 and $3600 \mathrm{~m}$ over the extensive high plateaus of Iouzagner (3502 $\mathrm{m})$ and Tazaghart $(3980 \mathrm{~m})$. Hannah et al. (2017) described large polygonal and linear patterned ground (10-20 m wide and up to $1000 \mathrm{~m}$ long) as well as extensive covering of thick regolith, blockfields, blockstreams and smaller-scale stone stripes on these high plateaus. The plateaus were covered in ice during the most extensive glacial phase of the Last Glaciation (before $\sim 50$ ka based on dating in Hughes et al. 2018) and the periglacial features formed afterwards and are probably still active today given the high altitude of the plateau.

Figure 13

\section{Deglaciation}

Few observations exist for the deglaciation phase. However, the rock glaciers reported for the M'Goun Massif by Wiche (1953) which are located inside the valleys well-within the glacier limit can be included in this phase. These features are probably derived from frontal moraines in the cirques, as suggested by Hughes et al. (2006). It is also possible that the rock glaciers described by Awad (1963) for the Middle Atlas, close to the Djebel Bou Naceur, as well as some of the High Atlas rock glaciers described by Dresch (1941) and Wiche (1953) also correspond to this phase.

\section{Present-day}

Observations on present-day periglacial processes and landforms are scarce and lack quantitative data. The lack of a common methodology by the different authors limits a regional analysis. Messerli (1973) shows that the Tibesti and Hoggar lack present-day frost activity, a fact that they attribute more to the dryness than to the lack of sub-zero temperatures. At the Aurés Massif, Tihay (1973) indicates that frost action occurs above $2300 \mathrm{~m}$, while Ballais (1981) mentions solifluction between 1300 and $1800 \mathrm{~m}$. For the Algerian Tell, Tihay (1973) lowers these limits, putting frost action above $1500 \mathrm{~m}$. In the Middle Atlas, Dresch and Raynal (1952) and Raynal et al. (1956) indicate active frost shattering. Above $2700 \mathrm{~m}$ a marginal periglacial zone starts to be evident in the eastern part of the Bou Naceur massif, with vegetation crescents and very shallow solifluction.

The most consistent reports on present-day periglacial activity in North Africa are from the Djebel Toubkal massif in the High Atlas, the highest peak in north Africa. Periglacial features are widespread (Hughes et al., 2011) and were described for the Central High Atlas by Couvreur (1966), who reported active solifluction above $2200 \mathrm{~m}$ (Figure 14). For the western High Atlas, Chardon and Riser (1981) indicate the limit of frost activity to be around $2500 \mathrm{~m}$ and considered that frost action dominates the morphogenesis above $3000 \mathrm{~m}$. Chardon and Riser (1981), seemingly were the first to interpret a lobate feature in the Irhzer Ikhibi south at $3800 \mathrm{~m}$ as an active rock glacier. Vieira et al. (2017) installed a series of ground surface temperature and air temperature dataloggers during one full year, from 3210 to $4160 \mathrm{~m}$ altitude. The authors analysed the ground temperature regimes and snow cover and identified a hot season from late-May to lateSeptember and a long cold season from mid-October to mid-April. Freeze-thaw regimes were analysed and the most important finding was the possible presence of permafrost at a location close to the rock glacier identified by Chardon and Riser (1981). This interpretation was based on the very low temperatures $\left(\right.$ c. $\left.-5.8^{\circ} \mathrm{C}\right)$ measured at the ground surface beneath a stable snow pack that lasted from mid-December until late-March. Other lobate rock debris features are found at similar altitudes in other cirques nearby and it is possible that these are also associated with sporadic patches of permafrost (Hughes, 2018). Permanent snowfields were present in the High Atlas in the mid-20th century and were probably widespread in the LIA (Hughes, 2018). 
Figure 14

\subsection{Mediterranean islands}

The Mediterranean Sea encompasses several archipelagos and some major islands, some of which exceed 10,000 km² (Sicily, Sardinia, Corsica, Crete). Some of the islands are very mountainous, with elevations exceeding $2000 \mathrm{~m}$ in Sicily (Etna, $3350 \mathrm{~m}$ ), Corsica (Monte Cinto, $2706 \mathrm{~m}$ ), Crete (Lefka Ori, $2452 \mathrm{~m}$ ). Lithologies are highly variable, with abundant limestones and granites and also volcanic rocks in the case of the highest elevation within the limits of the Mediterranean Sea, the Etna. While past glacial activity in Mediterranean islands has received some attention (e.g. Hughes et al., 2006a, Hughes and Woodward, 2016), periglacial processes have been less examined.

\section{Last Glaciation}

Glaciation has affected the mountains of Corsica, and the active volcano of Mt. Etna in Sicily, and the mountains of Crete. In the highest mountains in Corsica, Kuhlemann et al. (2008) dated roches moutonnées at $18 \mathrm{ka} \mathrm{BP}$. In Crete, Bathrellos et al. (2014) found 17 glacial cirques between 1870 and $2360 \mathrm{~m}$ distributed around the two main mountains groups: Mt. Lefka Ori $(2453 \mathrm{~m})$ and Mt. Idi $(2456 \mathrm{~m})$. However, the ages of the Cretan glaciations remain untested and could potentially be older than the Late Pleistocene as in parts of mainland Greece (cf. Hughes et al., 2007).

Past periglacial activity has been documented in several Mediterranean islands associated in most of the cases to seasonal frost regime. In Corsica, despite the quite extensive glaciation during the LGM periglacial landforms are not common if we exclude granite weathering features like tafoni, weathering pits or grooves that are extensively widespread in the island and that occur largely also in modern cryotic conditions in Antarctica (i.e Guglielmin et al., 2005; Strini et al., 2008). Kuhlemann et al. (2009) recorded blockfields and tors above $2200 \mathrm{~m}$ and describe them as possible periglacial landforms, even reporting less common similar features at lower altitudes.

Landforms associated to intense periglacial conditions are also observed in Sardinia as indicated by Ginesu (1990) who described several blockfields and block streams composed by basalts in the centre of the island (Pranu Mannu plateau) at an altitude of about $600 \mathrm{~m}$. Ginesu and Sias (2006) suggested a periglacial origin also for other block accumulations on different lithologies in the higher reliefs of Sardinia (Gennargentu, Limbara, Perdasdefogu). More recently, Ginesu et al. (2014) interpreted some block deposits found on Asinara island as block streams. In this case, block streams are composed by granites subrounded blocks and located close to the coast and even below the present sea level ( $4 \mathrm{~m}$ depth) in Cala Arena. Block streams and block slopes close to Tyrrenian coast have been described in the Pisani Mountains between 400 and $800 \mathrm{~m}$ on quarzites by Casarosa and Pappalardo (2006).

Poser (1957) found patterned ground and solifluction lobes above $1800 \mathrm{~m}$ in Crete, suggesting that the lower limit of periglacial activity in this island was represented by boulder pavements extending down to elevations of $800 \mathrm{~m}$. Cemented stratified scree of unknown age are present on the southern slope of Mt. Idi (Guglielmin, unpublished), probably related to the coldest phases of the Last Glaciation.

In the Balearic Islands there is evidence of periglacial activity during the Last Glaciation, with scree deposits located at elevations above $1200 \mathrm{~m}$ in the limestone Tramuntana massif (Rosselló, 1977) though no evidence of permafrost conditions was detected at this altitude. 
Deglaciation

The temperature increase recorded following the LGM conditioned the deglaciation of Mediterranean mountains, with only the possible existence of minor glaciers during the OD and YD in the highest mountains in Corsica. No evidence of permafrost conditions has been reported for this stage, though periglacial processes driven by seasonal frost may have existed during the coldest stages in the highest mountains.

\section{Holocene}

It is very unlikely that climate conditions prevailing during the Holocene allowed the existence of permafrost even in the high lands of the major islands.

\section{LIA and present-day}

LIA cold-climate conditions probably reactivated periglacial processes in the highest mountains in Sardinia and Sicily. In fact, evidence of permanent ice deposits in lava tubes has been found at $2043 \mathrm{~m}$ on the north flank of Mt Etna volcano (Grotta del Gelo, Cave of Frost), in Sicily. It is probably the southernmost European ice cave (Marino, 1992; Hughes and Woodward, 2009; Scoto et al., 2016). The lava tube formed during the historic long-lasting eruption of 1614-24 and despite its geological setting and latitude, after about twenty years from the last phases of the eruption (coinciding with the Minimum Maunder, 1645-1715), subterranean freezing inside the cave started to take place. Beside the development of seasonal ice formations (seasonal lake ice, ice stalactites, stalagmites and columns generally located close to the entrance), perennial ground ice is present in the deepest zone. The ice extension reaches about $240 \mathrm{~m}^{2}$, and the volume is estimated at about 220-260 m (Scoto et al., 2016). On Mt. Etna, at elevations above $2900 \mathrm{~m}$, nivo-aeolian deposits were found with frozen ground beneath that can persist for more than 2 years, and therefore can be considered as current permafrost (Guglielmin, unpublished).

\section{Discussion}

Climate variability during the Quaternary has conditioned the spatial distribution of glacial and periglacial processes in the Mediterranean region, and therefore the area under permafrost conditions (Figure 15). Glacial stages favoured a substantial expansion of glaciers in the currently still glaciated mountain ranges and the formation of glaciers in presently deglaciated mountain environments (Woodward, 2009). The glaciation in the Mediterranean mountains has been long debated and several reviews have focused on the calendar and geography of the maximum glacial expansion in the different mountain regions (i.e. Allen et al., 1999; Hughes et al., 2006a, 2008, 2013; Hughes and Woodward, 2016). The temperature increase recorded during interglacial phases - such as the Holocene - conditioned the complete disappearance or substantial retreat of glaciers and the migration of permafrost and periglacial processes to higher elevations (i.e. Oliva et al., 2016b).

\section{Figure 15}

\subsection{Last Glaciation}

The calendar of the maximum glacial expansion of the Last Glaciation shows a diachronous pattern among the massifs, which must be also framed with the dating method used in each study (Hughes et al., 2013). Whereas radiocarbon, U-series and OSL indicate an early glacial advance that occurred several thousand to tens of thousands of years earlier than the global LGM in the Sierra Nevada, Cantabrian Mountains, Central Pyrenees, Italian Apennines and Pindus Mountains, cosmogenic exposure ages suggest a local MIE in the Iberian Central Range, Maritime Alps and Anatolia mountains (almost) synchronous to the LGM (Hughes et al., 2008). 
The FIS extended over northern Europe until latitude $50^{\circ} \mathrm{N}$ in its southern fringe (Hughes et al., 2015; Stroeven et al., 2016). Therefore, the Mediterranean region was not extensively glaciated by comparison, with glaciers concentrated in mountain environments in the form of small ice caps and mountain glaciers filling the valleys. The ELA decrease in Mediterranean mountains during the LGM compared to present-day was about 800 and $1200 \mathrm{~m}$, which is translated in a minimum temperature difference of ca. 6-10 ${ }^{\circ} \mathrm{C}$ (Allen et al., 2008; Kuhlemann et al., 2008). The glaciated environments in the western and central Mediterranean region was associated with ELAs above 1500-2000 m in most of mountain ranges (Hughes et al., 2006a, 2008), slightly increasing towards the easternmost fringe in mountains of Turkish and Lebanon where the ELA was located around 2500-3000 m (Messerli, 1967).

The southern ice-free land surrounding the large FIS was underlain by permafrost, which extended across the lowlands in much of central Europe as well as the northern fringe of the Mediterranean region, in areas such as central France and the northern Balkan region (Brown, 2001; Vandenberghe et al., 2014). Dry and cold climate conditions prevailing in these permafrost areas during the LGM promoted intense aeolian activity, with the deposition of thick loess deposits in non-glaciated environments from central-northern Europe (Antoine et al., 2009) and northern Italy (Cremaschi et al., 2015). In the Mediterranean region, the presence of ice wedges and cryoturbations features in some basins, such as in the Pannonian basin (van Vliet- Lanoe et al., 2004; Ruszkiczay-Rüdiger and Kern, 2015) or in some basins in the Spanish Meseta (Badorrey et al., 1970; Asensio-Amor and González-Martín, 1974; Serrano et al., 2010a) has been related to deep seasonal frost conditions or even isolated patches of sporadic permafrost. Despite few data in areas surrounding the valley glaciers in the southern Alps, environments at the foot of the northern Apennines and even at the Po plain should have been affected by permafrost conditions as suggested by loess deposits and the existence of some cryoturbation features (Cremaschi et al., 2015). In the Mediterranean mountains, immediately below the glaciated environments was the periglacial belt affected by permafrost regime at high elevations and seasonal frost at the foot of the mountains and high-altitude plateaus (e.g. 600-1200 m).

Permafrost was also widespread in non-glaciated environments above the snowline as revealed by the present-day distribution of inactive permafrost-derived features. Rock glaciers formed during the Last Glaciation have been described in several Mediterranean mountains at a wide range of altitudes (e.g. Figure 3 and Table 5). Block streams, some $\mathrm{km}$ long and hundreds of meters wide, also developed during this stage at elevations between 700 and $1800 \mathrm{~m}$. In relatively flat summit areas where wind action did not favour snow and ice accumulation, meter-sized stone circles developed in several massifs except for the Italian Peninsula where there are no evidences of large stone circles in the LGM ice-free areas. Similar patterned ground features are observed today in present-day polar environments where permafrost conditions are widespread with mean annual temperatures below $-6^{\circ} \mathrm{C}$ (French, 2007). It is therefore feasible to relate the formation of these currently inactive features to permafrost occurrence. Concurrently, very intense periglacial conditions favoured the development of large blockfields and tors, which are remnants of original surfaces in the highest lands. The thermal regime of the ground in the nunataks standing out the glaciated slopes must have been also characterized by permanent frozen conditions well below 0 ${ }^{\circ} \mathrm{C}$.

\subsection{Deglaciation}


During the most important phases of the last deglaciation, the evolution of the glaciers of the different Mediterranean mountains shows a much more homogenous pattern than during the LGM. The latest studies indicate interruptions during the deglaciation process and even some important glacial advances, in full synchrony within the Mediterranean region and with the mountainous systems of central Europe, as well as with the FIS. The onset of a massive retreat of the FIS is dated at $19 \mathrm{ka}$ and accelerated at $18 \mathrm{ka}$ (Marks, 2015; Stroeven et al., 2015; Toucanne et al., 2015; A.L. Hughes et al., 2016; Petrini et al., 2018), in parallel to most European mountains. For example, some of the largest glaciers in the Alps had lost ca. $80 \%$ of their mass at $18 \mathrm{ka}$ (IvyOchs et al., 2004, Ivy-Ochs, 2015) and glaciers could almost have disappeared completely in the Pyrenees at that time, as probably occurred in many other Mediterranean mountains (Palacios et al., 2017a).

The first glacial advance within the deglaciation took place during the OD, when advances have been detected in numerous sectors of the FIS (Marks, 2015; Stroeven et al., 2015; Toucanne et al., 2015; A.L. Hughes et al., 2016). In the Alps, glaciers expanded along the valley bottoms with their fronts reaching elevations only $400 \mathrm{~m}$ above the LGM moraines (Kerschner and Ivy-Ochs, 2008; Ivy-Ochs et al., 2009; Ivy-Ochs, 2015). Similar glacial advances occurred during this period in the Tatra Mountains (Makos, 2015) as well as Mediterranean glaciers that also experienced important advances, as in the Iberian Peninsula (Palacios et al., 2017a), Southern Alps (Federici et al., 2012), Apennines (Giraudi, 2015), Balkan Peninsula (Kuhlemann et al., 2013) and Anatolian Peninsula (Sarıkaya et al., 2008, Akçar et al., 2014). A significant drop of the North Atlantic temperature induced a significant reduction of the meridional overturning circulation (Bard et al., 2000; McManus et al., 2004), with extreme seasonality of cold winters and mild summers (Denton et al., 2005; Williams et al., 2012) favouring glacial expansion during this period. Similar conditions have also been detected in southern Europe and in the Mediterranean region (Fletcher et al., 2010). For example, glaciological models indicate that during the OD the MAAT in the Alps was $10{ }^{\circ} \mathrm{C}$ lower than present-day, and precipitation was one-third less (IvyOchs, 2015). Undoubtedly, these conditions would have favoured a substantial expansion of permafrost conditions in mountain environments. Many fossil periglacial landforms existing in Mediterranean regions, such as patterned ground, protalus lobes or rock glaciers, could have originated at this time. But these climatic conditions changed drastically during the $\mathrm{BO}$, when the environmental conditions shifted abruptly and become very similar to present in the Mediterranean region (Fletcher et al., 2010). Consequently, there was a massive glacial retreat in Europe, including the FIS and British-Irish Ice Sheet (Marks, 2015; Stroeven et al., 2015; Toucanne et al., 2015; Hughes et al., 2016), central European mountains (Ivy-Ochs, 2015; Makos, 2015) and Mediterranean mountains (Sarikaya et al., 2008; Federici et al., 2012; Kuhlemann et al., 2013; Akçar et al., 2014; Giraudi, 2015; Palacios et al., 2017a).

The recent application of absolute dating methods, fundamentally cosmogenic, to fossil rock glaciers is allowing a better comprehension of the timing of their formation and stabilization, remaining therefore exposed to cosmogenic radiation. In many European mountains, this method is showing that numerous rock glaciers developed on polished glacial surfaces that were deglaciated just at the end of OD. In many cases, the fronts of these rock glaciers were stabilized soon after formation, although their roots remained active during thousands of years (Oliva et al., 2016b, Palacios et al., 2017a,b). This fact shows evidence that most fossil rock glaciers in different Mediterranean mountain ranges developed under paraglacial conditions (Ballantyne, 2002; Mercier, 2008; Oliva et al., 2016b). They occupied the formerly glaciated cirques, extending over very active geomorphological areas at the end of the OD. Subsequently, as 
temperatures increased during the OD permafrost conditions migrate to higher elevations and rock glaciers became relict. This process has been mostly described in many Iberian mountain environments (Rodríguez-Rodríguez, 2016; Fernández-Fernández, 2017; Palacios et al., 2017a,b), and should be tested in the future in other Mediterranean ranges. Noteworthy, a similar pattern has been also reported in other mountains, such as in the British Isles (Ballantyne et al., 2009) and the Alps (Hippolyte et al., 2009).

During the YD, in full agreement with the last major advance of the FIS (Greenwood et al., 2015; A.L. Hughes et al., 2016; Stroeven et al., 2015), Mediterranean glaciers advanced again for the last time during the Pleistocene, but only in the highest massifs. Glaciers rarely exceeded the limits of the cirques in the Pyrenees (García-Ruiz et al., 2016a,b) and were moderately longer in the southern Alps (Ivy-Ochs et al., 2008, 2009). This glacial advance was related to a cold and arid period during the YD in the Mediterranean region that ended abruptly at $11.8 \mathrm{ka}$ cal BP (Fletcher et al., 2010). In the Alps, where glaciers had virtually disappeared during the BO, they formed again during the YD and progressed considerably (Ivy-Ochs, 2015) due to $3.5-5^{\circ} \mathrm{C}$ lower MAAT than present and precipitation was up to $30 \%$ less (Kerschner and Ivy-Ochs, 2008). A similar pattern was also detected in the Tatra Mountains (Makos, 2015).

As occurred at the end of the OD, the end of the YD favoured the rapid retreat of glaciers and, in some cases, the reactivation of paraglacial processes in the walls of the cirques and the formation of rock glaciers and protalus lobes. Again, their fronts became inactive soon after formation, while the roots could have remained active even until the warmest Holocene periods (García-Ruiz et al., 2016a,b; Oliva et al 2016b). Many generations of Mediterranean rock glaciers have been considered to form during or at the end of the $\mathrm{YD}$, as reported in many Iberian mountains (Palacios et al., 2015, 2016; Andrés et al., 2018) and southern Alps (Colucci et al., 2016a), though in other high mountain Mediterranean regions this fact still needs to be confirmed.

Therefore, the cold periods interrupting the long-term deglaciation process showed both glacial and periglacial evidence in the Mediterranean mountains, mainly with the formation of permafrost-related features associated with paraglacial dynamics. The existence of these inactive landforms suggests the minimum altitude for the presence of permafrost during these stages.

\subsection{Holocene}

The northern Atlantic region has been subjected to significant climate shifts during the Holocene, as revealed by marine sediment records (Witak et al., 2015) and Greenland ice cores (MassonDelmotte et al., 2005). Climate variability has been also significant across the Mediterranean region, where Holocene temperature oscillations of the order of ca. $\pm 2{ }^{\circ} \mathrm{C}$ have caused significant disruptions in early civilizations (Mayewski et al., 2004). During the Holocene, temperature and moisture shifts have also affected the type and intensity of cold-climate geomorphological processes prevailing in Mediterranean mountains.

The onset of the Holocene saw an accelerated shrinking of the glaciers, which disappeared until nowadays in many massifs during the Early Holocene (Gómez-Ortiz et al., 2012a; García-Ruiz et al., 2016a,b; Palacios et al., 2016). The formerly glaciated environments became occupied by periglacial dynamics, which expanded gradually upvalleys (Oliva et al., 2016b). In many midaltitude mountain ranges - with highest peaks around $2000 \mathrm{~m}$ in the central and western Mediterranean and 2500-3000 $\mathrm{m}$ in the eastern part of the region - the periglacial belt disappeared during the Holocene, and significantly shrunk in the highest ranges, particularly during the 
warmest stages, such as the Holocene Warm Period (HWP) and the Medieval Climate Anomaly (MCA). In the southern Alps, even during warmer Holocene stages some currently active rock glaciers were still active (Calderoni et al., 1998; Stenni et al., 2007; Scapozza et al., 2010); indeed, the major part of the dated rock glaciers reported an age between 2720 and $2850 \mathrm{cal}$ yr BP with some older exceptions (all younger than 5900 cal yr BP; Calderoni et al., 1998; Guglielmin et al., 2001; Dramis et al, 2003). During the warmest phases, only the environments above 2500-3000 $\mathrm{m}$ included a periglacial belt mostly related to seasonal frost conditions, with permafrost regime limited to the highest ranges in the Maritime Alps and the highest mountains in Anatolia.

Most of the active periglacial features during the YD became gradually inactive, and only reactivated during the coldest stages of the Holocene. Permafrost-related features showed activity until the Early Holocene in many of the highest Mediterranean massifs (Kuhlemann et al., 2009; Gómez-Ortiz et al., 2012a; Palacios et al., 2016, 2017a,b). Some authors proposed the initial formation of currently active rock glaciers synchronously to the HWP, such as in the central Taurus Mountains (Çiner et al., 2017) and the Pyrenees at ca. 6 ka (Serrano et al., 2010c). Periglacial landforms related to seasonal frost conditions, such as solifluction landforms located today in the present-day periglacial belt of Sierra Nevada at elevations between 2500 and 3000 $\mathrm{m}$, were inactive during the HWP until $5 \mathrm{ka}$ cal BP but reactivated later during cold and wet phases, namely at 5-4, 3.6-3.4, 3-2.8, 2.5-2.3, 1.8-1.6, 0.85-0.7, 0.4-0.15 ka cal BP (Oliva et al., 2011). Therefore, the alternation between cold and warm phases during the Holocene accompanied also by changing precipitation regimes must have also influenced the intensity of periglacial processes and the spatial distribution of permafrost conditions.

\subsection{Little Ice Age}

The LIA has been defined as the coldest most recent period where many glaciers reached their largest volume over the last 10,000 years (Bradley and Jones, 1992), and, thus, it has been widely employed in mid-latitude mountain environments as the reference for Holocene cold stages (Grove, 2004; Oliva et al., 2018). In the Mediterranean region, colder and (generally) wetter than present-day climate conditions prevailing during the LIA also favoured the presence of larger and more numerous glaciers (Hughes, 2014). Consequently, the spatial domain of periglacial dynamics expanded down-valleys and cryogenic processes reappeared in some areas where seasonal frost activity was limited during the MCA and is no longer active at present.

During the LIA permafrost features such as rock glaciers and protalus lobes formed and/or reactivated in the highest slopes of the main massifs, above $2350 \mathrm{~m}$ in some areas of the Balkan region and $2560 \mathrm{~m}$ in the Pyrenees (Tables 6 and 2). In the southern Alps, especially in the eastern part several rock glaciers developed since the LIA around 2400-2500 m (Baroni et al., 2004; Seppi et al., 2014) while only a few active rock glaciers formed in the western Alps and central Alps.

Ice caves, namely natural caves formed in bedrock containing perennial accumulations of ice, are considered as sporadic permafrost phenomena (Holmlund et al., 2005; Luetscher et al., 2005; Hausmann and Behm, 2011; Luetscher et al., 2013). As part of the cryosphere, ice caves occurrence is closely linked to cold climates, even if they do also exist in different kind of environments, often at an altitude with an outside mean annual air temperature well-above $0^{\circ} \mathrm{C}$ (Holmlund et al., 2005; Stoffel et al., 2009; Obleitner and Spötl, 2012; Colucci et al., 2016b). Ice caves existing in several high karstic mountains have been examined for paleoenvironmental purposes. In most cases these ice caves are several hundreds of meters below the glaciated environments during the LIA, reaching elevations even below $1000 \mathrm{~m}$ in the Dinaric Alps (Kern 
et al., 2006b; Bočić et al., 2014). The dating of the organic remnants preserved in the ice suggests that it accumulated during the coldest centuries of the LIA (Bayar1 et al., 2003; Kern et al., 2006b; Klimchouk et al., 2006; Bočić et al., 2014; Gómez-Lende, 2015; Bartolomé et al., 2015; Temovski, 2016; Zupan-Hajna, 2016; Sancho et al., 2016), and even during the MCA and HWP (Sancho et al., 2016). Interestingly, the frozen ground in contact with the ice inside the caves has been also described as permafrost (Gómez-Lende, 2015; Colucci et al., 2016b), which in many cases still persist in environments with MAAT well above $0{ }^{\circ} \mathrm{C}$ due to specific microtopographic conditions (very low solar radiation, existence of stable temperature inversion or density driven air flows and chimney effects).

In all Mediterranean massifs, long-lasting and perennial snow-patches were more extensive than today, which also enhanced nival processes that left some small well-preserved landforms such as protalus ramparts at the foot of slopes.

\subsection{Present-day}

In the western Mediterranean region, the temperature increase since the last cold stages of the LIA has been estimated at ca. $1{ }^{\circ} \mathrm{C}$ (González-Trueba, 2006; González-Trueba et al., 2008; Oliva and Gómez-Ortiz, 2012) and ca. $2^{\circ} \mathrm{C}$ since the Minimum Maunder (Oliva et al., 2018). A similar increase has been inferred for other parts of the Mediterranean, such as in the Balkans (Repapis and Philandras, 1988 Xoplaki et al., 2001; Hughes, 2010). This temperature increase has led to glacial retreat/disappearance (Zumbühl et al., 2008), enhanced paraglacial activity (Cossart and Fort, 2008), shift of periglacial processes to higher elevations (Oliva et al., 2011), geoecological changes (Cannone et al., 2007, 2008; Pauli et al., 2012; García-Ruiz et al., 2015; Camarero et al., 2016), as well as degradation of alpine permafrost in mid-latitude high mountain environments, e.g. the Alps (Harris et al., 2003; Gruber et al., 2004; Lugon et al., 2004; Zenklusen-Mutter et al., 2010).

A wide range of approaches have been used to infer the current altitudinal limit of permafrost conditions, such as geomorphological techniques, geophysical surveying and monitoring activities (BTS measurements, boreholes, terrain deformation). Today, permafrost conditions generally increase in elevation towards the eastern part of the region and from north to south. In the western and central Mediterranean, permanently frozen ground is rarely found below $2500 \mathrm{~m}$, discontinuous permafrost is generally detected between 2500 and $2800 / 3000 \mathrm{~m}$ and continuous permafrost is distributed in ice-free environments above this level. An alpine permafrost belt is detected above $2630 \mathrm{~m}$ in northern aspects and $2800 \mathrm{~m}$ in southern ones in the Pyrenees (Serrano et al., 1999, 2001, 2002, 2006, 2009, 2011a; González-García et al., 2014), above $2400 \mathrm{~m}$ in the Southern Alps (Bodin et al., 2009), above $2350 \mathrm{~m}$ on Rila Mountain and $\sim 2700 \mathrm{~m}$ on Mount Olympus (Dobinski, 2005) and above 2800-3400 $\mathrm{m}$ in NE Turkey and central Anatolia (Gorbunov, 2012). No permafrost belt is found in the highest mountains in southern Europe (i.e. Sierra Nevada) and northern Africa (i.e. Atlas) where permanent frozen conditions are only found in form of isolated patches at the highest elevations at 3000-3100 $\mathrm{m}$ (Oliva et al., 2016a) and 3800 m (Vieira et al., 2017), respectively. Certain climate conditions (i.e. reduced snow cover) can favour the presence of permafrost patches at relatively low elevations in the Central Apennines on La Majella and M. Velino massifs (ca. $2400 \mathrm{~m}$ ) or by lithological conditions (i.e. volcanic sediments), as detected in the highest active European volcano (Mt. Etna) at elevations above $2900 \mathrm{~m}$ 
Scientific papers and international reports coincide in anticipating that the Mediterranean basin will be one of the areas on Earth where annual and seasonal climate variations will be more pronounced, with significant warming and reduced rainfall (e.g. IPCC, 2013). These climate conditions would lead to a migration of permafrost conditions to upper elevations, even disappearing in those areas where isolated patches persist but undergo a rapid degradation process (e.g. Atlas, Sierra Nevada Cantabrian Mountains), possibly triggering large rock avalanches or other mass wasting processes with important socio-economic impacts.

\section{Conclusions}

The present and past distribution of cold-climate geomorphological processes in the Mediterranean region is conditioned by the topography and wide spectrum of microclimatic conditions prevailing in the region. Both glacial and periglacial processes (including permafrost conditions) since the Last Glaciation have been almost exclusively restricted to mountain environments.

Since the Last Glaciation there has been a long-term decrease in the area occupied by permafrost in the Mediterranean mountains. The existence of abundant inactive permafrost-derived landforms (rock glaciers, block streams, patterned ground features, ice wedges) formed during the last Pleistocene glacial cycle suggests that ice-free slopes in mid-altitude mountain environments and high summit plateaus together with the lowlands of the northernmost fringe of the Mediterranean region could have been underlain by permafrost conditions to a greater or lesser extent during that stage. The thermal increase following the LGM meant that, after that time, periglacial conditions were limited to mountain areas. The gradual upward shift of the snowline in all Mediterranean massifs conditioned a massive deglaciation that was only interrupted by brief periods of glacial readvance. Paraglacial dynamics during the deglaciation process favoured the development of most of the rock glaciers distributed in the majority of the massifs, almost all of which are inactive under present-day climate conditions. Therefore, their formation is primarily associated with adjustment of the cirque walls to a new morphodynamic setting and not strictly related to a climatic origin. Warmer temperatures during the onset of the Holocene saw a shrinking of periglacial activity to the highest elevations. Many rock glaciers and protalus lobes became inactive during the Early Holocene as temperatures rose. Permafrost disappeared from most of the massifs and only reappeared in some mountains during the coldest stages of the Holocene, such as the LIA. Since then, post-LIA warming led to the spatial confinement of continuous/discontinuous permafrost conditions in the highest mountain areas, such as some areas in the Pyrenees, Southern Alps, Apennines and Anatolian mountains, or as isolated patches in north-facing cirques that were glaciated during the LIA in the Sierra Nevada, Atlas Mountains and the Balkan region.

In contrast to neighbouring mountain environments where there has been a richer analysis of permafrost history (i.e. Alps), permafrost research in the Mediterranean basin still has some gaps:

- The improvement of the glacial chronology that has taken place over the last decade in many Mediterranean massifs has not been paralleled by a strengthening of the chronology of periglacial activity, and therefore of permafrost evolution in the Mediterranean region.

- Data about periglacial dynamics and spatial domains of permafrost are substantial for certain periods (i.e. the last deglaciation), though current knowledge is still poor for others (i.e. Holocene). 
- Knowledge of permafrost evolution in some mountain environments is still limited, particularly in North Africa ranges, Apennines and Mediterranean islands.

- Future studies should focus on precise descriptions of landforms and quantitative age proxy data, especially on rock glaciers as indicators of present and past permafrost conditions.

Finally, permafrost scientists in the Mediterranean region should focus on these gaps in order to better understand the spatio-temporal evolution of permafrost conditions in the region. A better characterization of the evolution of permafrost - a key component of the cryosphere in landscape dynamics in mid-latitude high mountain ranges - may be also helpful to anticipate the future geoecological response towards the changing climate scenarios forecasted in these highly sensitive mountain ecosystems.

\section{Acknowledgements}

This research was supported by the project CTM2017-87976-P of the Spanish Ministry of Economy, Industry and Competitiveness. Marc Oliva is supported by the Ramón y Cajal Program of the Spanish Ministry of Economy and Competitiveness (RYC-2015-17597) and the Research Group ANTALP (Antarctic, Arctic, Alpine Environments; 2017-SGR-1102) funded by the Government of Catalonia through the AGAUR agency. Attila Çiner and M. Akif Sarıkaya are grateful to TÜBİTAK (Project no: 101Y002, 107Y069, 110Y300, 112Y139, 114Y548T and 116Y155) for continuous support to the glacial/periglacial research in Turkey. The authors are grateful to Prof. Dr. Wilfried Haeberli for his valuable comments and suggestions that improved the manuscript. 


\section{References}

Akçar, N., Schlüchter, C., 2005. Paleoglaciations in Anatolia: A schematic review and first results. Eiszeitalter und Gegenwart, 55, 102-121.

Akçar, N., Yavuz, V., Ivy-Ochs, S., Kubik, P.W., Vardar, M., Schlüchter, C., 2007. Paleoglacial records from Kavron Valley, NE Turkey: Field and cosmogenic exposure dating evidence. Quaternary International, 164-165, 170-183.

Akçar, N., Yavuz, V., Ivy-Ochs, S., Kubik, P.W., Vardar, M., Schlüchter, C., 2008. A Case for a down wasting Mountain Glacier during the Termination-I, Verçenik Valley, NE Turkey. Journal of Quaternary Science, 23, 273-285.

Akçar, N., Yavuz, V., Ivy-Ochs, S., Reber, R., Kubik, P.W., Zahno, C., Schlüchter, C., 2014. Glacier response to the change in atmospheric circulation in the eastern Mediterranean during the Last Glacial Maximum. Quaternary Geochronology, 19, 17-41.

Akçar, N., Yavuz, V., Yeşilyurt, S., Ivy-Ochs, S., Reber, R., Bayrakdar, C., Kubik, P.W., Zahno, C., Schlunegger, F., Schlüchter, C., 2017. Synchronous Last Glacial Maximum across the Anatolian Peninsula. Geological Society, London, Special Publications, 433, 251-269. doi: 10.1144/SP433.7.

Akkan, E., Tuncel, M., 1993. Esence (Kesiş) Dağlarında Buzul Şekilleri, A.Ü. Coğrafyası Araştırma ve Uygulama Merkezi Dergisi, 2, 225-240.

Allen, J.R.M., Brandt, U., Brauer, A., Hubberten, H.W., Huntley, B., Keller, J., Kraml, M., Mackensen, A., Mingram, J., Negendank, J.F.W., Nowaczyk, N.R., Oberhansli, H., Watts, W.A., Wulf, S., Zolitschka, B., 1999. Rapid environmental changes in southern Europe during the last glacial period. Nature, 400, 740-743.

Allen, R., Siegert, M.J., Payne, A.J., 2008. Reconstructing glacier-based climates of LGM Europe and Russia - Part 2: A dataset of LGM precipitation/temperature relations derived from degree-day modelling of palaeo glaciers. Climate of the Past, 4, 249-263.

Alonso, V., 1989. Glaciares rocosos fósiles en el área Degaña-Leitariegos (Occidente de Asturias, Cordillera Cantábrica). Cuaternario y Geomorfolología, 3(1-4), 9-15.

Alonso, V., Trombotto, D., 2009. Periglacial geomorphology of El Miro area, Cantabrian Mountains, NW Spain. Zeitschrift für Geomorphologie, 53, 335-357.

Altın, T., 2006. Aladağlar ve Bolkar dağları üzerinde görülen periglasiyal jeomorfolojik şekiller. Türk Coğrafya Dergisi, 46, 105-122.

Andrés, N., Gómez-Ortiz, A., Fernández-Fernández, J.M., Tanarro, L.M., Salvador, F., Oliva, M., Palacios, D., 2018. Timing of deglaciation and rock glacier origin in the southeastern Pyrenees: a review and new data. Boreas, doi: 10.1111/bor.12324.

Antoine, P., Rousseau, D., Moine, O., Kunesch, S., Hatte, C., Lang, A., Tissoux, H., Zoller, L., 2009. Rapid and cyclic aeolian deposition during the Last Glacial in European loess: A highresolution record from Nussloch, Germany. Quaternary Science Reviews 28(25-26), 2955-2973.

Anzidei, M., Lambeck, K., Antonioli, F., Furlani, S., Mastronuzzi, S., Serpelloni, E., Vannucci, G., 2014. Coastal structure, sea level changes and vertical motion of the land in the Mediterranean. In: Martini I.P., Wanless H.R. (Editors), Sedimentary coastal zones from High to low latitudes: Similarities and Differences. Geological Society, London, Special Publications, 388 .

Arboleya, M. L., Teixell, A., Charroud, M., Julivert, M., 2004. A structural transect through the High and Middle Atlas of Morocco. Journal of African Earth Sciences, 39, 319-327. 
Arnáez, J., 1987. Formas y procesos de evolución de vertientes de la Sierra de la Demanda, Sistema Ibérico. Cuadernos de Investigación Geográfica, 13(1-2), 1-153.

Arnáez, J., García Ruíz, J.M., 2000. El periglaciarismo en el Sistema Ibérico Noroccidental. In: Peña, J.L., Sánchez- Fabre, M., Lozano, M.V. (Editors), Procesos y formas periglaciares en la montaña mediterránea. Instituto de Estudios Turolenses, Teruel, 113-126.

Arpat, E., Özgül, N., 1972. Orta Toroslar'da Geyik dağı yöresinde kaya buzulları. Bulletin of the Mineral Research and Exploration, 78, 30-35.

Asensio-Amor, I., 1974. Contribución al estudio de acciones periglaciares en el límite galaicoastur. Boletín del Instituto de Estudios Asturianos, 83, 805-809.

Asensio-Amor, I., González-Martín, J.A., 1974. Formas de crioturbación en altos niveles cuaternarios del valle del Jarama. Estudios Geográficos, 137, 579-591.

Assier, A., Fabre, D., Evin, M., 1996. Prospection électrique sur les glaciers rocheux du cirque de Sainte-Anne (Queyras, Alpes du Sud, France). Permafrost and Periglacial Processes, 7(1), 5367.

Atalay, I., 1983. Mescid dağının glasyal morfolojisi. Ege Coğrafya Dergisi, 2(1), 31-48.

Avc1, M., 2007. Noah's Ark: its relationship to the Telçeker earthflow, Mount Ararat, Eastern Turkey. Bulletin of Engineering Geology and the Environment, 66, 377-380.

Awad, H., 1963. Some aspects of the geomorphology of Marocco related to the Quaternary climate. Geographical Journal, 129, 129-139.

Badorrey, T., Guerra, A., Pinilla, A., 1970. Fenómenos de periglaciarismo en paleosuelos de la meseta castellana. Anales de Edafología y Agrobiología, 11-12, 931-940.

Bailey, G.N., Woodward, J.C., 1997. The Klithi deposits: Sedimentology, stratigraphy and chronology. In: G.N. Bailey (Editor), Klithi: Paleolithic settlement and Quaternary landscapes in northwest Greece. Volume 1: Excavation and intra-site analysis at Klithi. Cambridge: McDonald Institute for Archaeological Research, 61-94.

Balch, E.S., 1900. Glacières or Freezing Caverns. Philadelphia Allen, Lane \& Scott reprinted in 1970 by Johnson Reprint Corp., New York, 38 pp.

Ballantyne, C.K., 2002. Paraglacial geomorphology. Quaternary Science Reviews, 21(18-19), 1935-2017.

Ballantyne, C.K., Schnabel, C., Xu, S., 2009. Exposure dating and reinterpretation of coarse debris accumulations ('rock glaciers') in the Cairngorm Mountains, Scotland. Journal of Quaternary Science, 24(1), 19-31.

Ballais J.L., 1981. Recherches géomorphologiques dans les Aurès (Algérie). PhD thesis, University of Paris I.

Barbier, A., Cailleux, A., 1950. Glaciaire et périglaciaire dans le Djurdjura occidental (Algérie). Comptes Rendus des Séances de 1'Académie des Sciences, Paris. Juillet-Décembre 1950, 365-366.

Bard, E., Rostek, F., Turon, J.L., Gendeau, S., 2000. Hydrological impact of Heinrich Events into the subtropical Northeast Atlantic. Science, 289, 1321-1324.

Baroni, C., Carton, A., Seppi, R., 2004. Distribution and behaviour of rock glaciers in the Adamello-Presanella Massif (Italian Alps) Permafrost and Periglacial Processes, 15, 243-259. 
Barriendos, M., 1997. Climatic variations in the Iberian Peninsula during the late Maunder Minimum (AD 1675-1715): an analysis of data from rogation ceremonies. The Holocene, 7(1), 105-111.

Barsch, D., 1992. Permafrost creep and rockglaciers. Permafrost and Periglacial Processes, 3, 175-163.

Barsch, D., 1996. Rockglaciers: indicators for the present and former geoecology in high mountain environments. Springer, Berlin, $331 \mathrm{pp}$.

Bartolomé, M., Sancho, C., Osácar, M.C., Moreno, A., Leunda, M., Spötl, C., Luetscher, M., López-Martínez, J., Belmonte, A., 2015. Characteristics of cryogenic carbonates in a Pyrenean ice cave (northern Spain). Geogaceta, 58, 107-110.

Bayarı, S., Zreda, M., Çiner, A., Nazik, L., Törk, K., Özyurt, N., Klimchouk, A., Sarıkaya, M.A., 2003. The Extent of Pleistocene Ice Cap, glacial deposits and glaciokarst in the Aladağlar Massif: Central Taurids Range, Southern Turkey. Proceedings of the XVI INQUA Congress, Geological Society of America, 144-145.

Bayrakdar, C., Özdemir, H., 2010. Kaçkar Dă̆ı'nda bakı faktörünün glasiyal ve periglasiyal topografya gelişimi üzerindeki etkisi. Türk Coğrafya Dergisi, 54, 1-13.

Bayrakdar, C., Çılgın, Z., Döker, M.F., Canpolat, E., 2015. Evidence of an active glacier in the Munzur Mountains, eastern Turkey. Turkish Journal of Earth Sciences, 24, 56-71.

Bernini, M., Carton, A., Castaldini, D., Cremaschi, M., 1978. Segnalazione di un deposito di versante di tipo Grèzes liteès a sud di M. Prampa (alto Appennino reggiano). Gruppo Studio del Quaternario Padano, 4, 153-172.

Bertini, A., 2010. Pliocene to Pleistocene palynoflora and vegetation in Italy: State of the art. Quaternary International, 225, 5-24.

Bertrand, J.M.L., Caby, R., 1978. Geodynamic evolution of the Pan-African orogenic belt: A new interpretation of the Hoggar shield (Algerian Sahara). Geol Rundschau, 67, 357.

Bilgin, T., 1960. Kazdağı ve üzerindeki periglasiyal şekiller hakkında. Türk Coğrafya Dergisi, 20, 114-123.

Bilgin, T., 1969. Gavurdağ kütlesinde glasiyal ve periglasiyal topoğrafya şekilleri. İstanbul Üniversitesi Yayınları, 1494, 58 pp.

Bilgin, T., 1972. Munzur Dağları doğu kısmının glasiyal ve periglasiyal morfolojisi, İstanbul Üniversitesi Yayınları, 1757, 85 pp.

Birman, J.H., 1968. Glacial reconnaissance in Turkey. Geological Society of America Bulletin, 79, 1009-1026.

Bisci, C., Dramis, F., Fazzini, M., Guglielmin, M., 2003. Climatic conditions and sporadic permafrost in the Maiella Massif (Central Apennines, Italy). Geografia Fisica e Dinamica Quaternaria, 26(1), 3-13.

Bočić, N., Kern, Z., Buzjak, N., 2014. Some new potential subterranean glaciation research sites from Velebit Mt. (Croatia). In: Land, L., Kern, Z., Maggi, V., Turri, S. (Editors), Proceedings of the 6th international workshop on ice caves, 72-76.

Bockheim, J.G., Vieira, G., Ramos, M., López-Martínez, J., Serrano, E., Guglielmin, M., Wilhelm, K., Nieuwendam, A., 2013. Climate Warming and Permafrost Dynamics in the Antarctic Peninsula Region. Global and Planetary Change, 100, 215-223. 
Bodin, X., Thibert, E., Fabre, D., Ribolini, A., Schoeneich, P., Francou, B., Reynaud, L., Fort, M., 2009. Two decades of responses (1986-2006) to climate by the laurichard rock glacier, French Alps. Permafrost and Periglacial Processes, 20(4), 331-344.

Bodin, X., Schoeneich, P., Deline, P., Ravanel, L., Magnin, F., Krysiecki, J.M., Echelard, T., 2015. Mountain permafrost and associated geomorphological processes: recent changes in the French Alps. Revue de Géographie Alpine, 103(2), 2885.

Bodin, X., Krysiecki, J.M., Schoeneich, P., Le Roux, O., Lorier, L., Echelard, T., Peyron, M., Walpersdorf, A., 2017. The 2006 collapse of the Bérard Rock Glacier (Southern French Alps). Permafrost and Periglacial Processes, 28(1), 209-223.

Boeckli, L., Brenning, A., Gruber, S., Noetzli, J., 2012. Permafrost distribution in the European Alps: calculation and evaluation of an index map and summary statistics. The Cryosphere, 6, 807-820.

Boenzi, F., 1980. Some evidence of Quaternary cold periods in Southern Italy: data and reflections. Rivista di Geografia Fisica e Dinamica Quaternaria, 3, 16-20.

Boenzi, F., Palmentola, G., 1975. Effetti di fenomeni glaciali quaternari nella Calabria nordoccidentale. Bollettino della Società Geologica Italiana, 94(4), 871-887.

Boenzi, F., Pennetta, L., DiGennaro, M.A., 1977. Osservazioni geologiche e morfologiche sul bordo occidentale delle Murge tra Fermata di Acquatetta e Lamapera (Bari). Bollettino della Società Geologica Italiana, 96, 169-180.

Boixadera, J., Antúnez, M., Poch, R.M., 2008. Soil evolution along a toposequence on glacial and periglacial materials in the Pyrenees Range. In: Kapur, S., Mermut, A, Stoops, G. (Editors), New Trends in Soil Micromorphology. Springer Verlag, Berlin, 39-65.

Bommer, C., Phillips, M., Arenson, L.U., 2010. Practical recommendations for planning, constructing and maintaining infrastructure in mountain permafrost. Permafrost and Periglacial Processes, 21, 97-104.

Bornet, D., Bodin X., Schoeneich P., Charvet R., Bouvet P., Caubet D, Andréis N., Riguidel A., 2014. The rock glaciers inventory in the Southern French Alps. In: Vieira, G., Pina, P., Mora, C., Correia, A. (Editors), Proceedings of the Fourth European Conference On Permafrost, University of Lisbon and University of Évora, 503.

Bozilova, E., Tonkov, S., 2000. Pollen from Lake Sedmo Rilsko reveals southeast European postglacial vegetation in the highest mountain area of the Balkans. New Phytologist, 148, 315325 .

Bozkurt, E., 2001. Neotectonics of Turkey - a synthesis. Geodinamica Acta, 14, 3-30.

Bradley, R.S., Jones, P.D., 1992. Climate since 1500 A.D. Routeledge, London, 679 pp.

Brancaccio, L., 1968. Genesi e caratteri delle forme costiere nella Penisola Sorrentina. Bollettino della Società Geologica Italiana, 96, 169-180. 360.

Bronk Ramsey, C., 2009. Bayesian analysis of radiocarbon dates. Radiocarbon, 51(1), $337-$

Brown, J., Ferrians, O.J., Heginbottom, J.A., Melnikov, E.S., 2001. Circum-arctic map of permafrost and ground ice conditions. Circum-pacific map series. Reston, VA: US Geological Survey.

Brunetti, M., Lentini, G., Maugeri, M., Nanni, T., Auer, I., Böhm, R., Schöner, W., 2009. Climate variability and change in the Greater Alpine Region over the last two centuries based on multi-variable analysis. International Journal of Climatology, 29, 2197-2225. 
Burić, D., Micev, S., 2008. Kepenova podjela klima u Crnoj gori prikazana klimadijagramima po Valteru.

Buzjak, N., Bočić, N., Paar, D., Dubovečak, V., 2016. Geographical distribution and ice cave types in Croatia. In: Mihevc, A., Zupan Hajna, N., Gostinčar, P. (Editors), Proceedings of the 7th International Workshop on Ice Caves, 37-38.

Buzjak, N., Dubovečak, V., Paar, D., Bočić, N., 2014. The influence of karst topography to ice cave occurrence - Example of Ledena jama in Lomska duliba (Croatia). In: Land, L., Kern, Z., Maggi, V., Turri, S. (Editors), Proceedings of the 6th International Workshop on Ice Caves, $17-23$.

Calderoni, G., Guglielmin, M., Tellini, C., 1998. Radiocarbon dating and postglacial evolution, upper Valtellina and Livignese area (Sondrio, central Italian Alps). Permafrost and Periglacial Processes, 9(3), 275-284.

Çalışkan, O., 2016. Dört farklı soğuk ortam topoğrafyası tek bir buzullaşma alanı üzerinde gözlenebilir mi? Karçal Dağları örneği (Doğu Karadeniz Bölümü/Türkiye). Marmara Coğrafya Dergisi, 33, 368-389.

Çalışkan, O., Gürgen, G., Yılmaz, E., Yeşilyurt, S., 2012. Bolkar Dağları kuzeydoğusunun glasyal morfolojisi ve döküntüyle örtülü buzulları. Uluslararası İnsan Bilimleri Dergisi, 9(1), 890911.

Cannone, N, Sgorbati, S, Guglielmin, M. 2007. Unexpected impacts of climate change on Alpine vegetation. Frontiers in Ecology and the Environment, 5, 360-364.

Cannone, N., Diolaiuti, G., Guglielmin, M., Smiraglia, C. 2008. Accelerating climate change impacts on alpine glacier forefield ecosystems in the European Alps, Ecological Applications, 18(3), 637-648.

Carrasco, R.M., Pedraza, J., Domínguez-Villar, D., Villa, J., Willenbring, J.K., 2012. The plateau glacier in the Sierra de Béjar (Iberian Central System) during its maximum extent. Reconstruction and chronology. Geomorphology, 196, 83-93.

Carrasco, R.M., Pedraza, J., Domínguez-Villar, D., Willenbring, J.K, Villa, J., 2015. Sequence and chronology of the Cuerpo de Hombre paleoglacier (Iberian Central System) during the Last Glacial Cycle. Quaternary Science Reviews, 129, 163-177.

Casarosa, N., Pappalardo, M., 2006. I Monti Pisani (Toscana settentrionale). In: Chelli, A., D’Aquila, P., Firpo, M., Ginesu, S., Guglielmin, M., Pappalardo, M., Pecci, M., Piacentini, T., Queirolo, C., Robustelli, G., Scarciglia, F., Sias, S., Tellini, C. (Editors), Testimoni di una montagna scomparsa. Contributo alle metodologie d'indagine delle forme periglaciali relitte. Problematiche e applicazioni in differenti ambienti morfodinamici. Collana «Quaderni della Montagna», vol. 8, Bologna: Bonomia University Press, 55-63.

Castañón, J.C., Frochoso, M., 1994. El periglaciarismo de la Cordillera Cantábrica. In: Gómez-Ortiz, A., Simón-Torres, M., Salvador-Franch, F. (Editors), Periglaciarismo en la Península Ibérica, Canarias y Baleares. Sociedad Española de Geomorfología, Universidad de Granada and Servei de Gestió i Evolució del Paisatge de la Universitat de Barcelona, Granada, $75-91$.

Castañón, J.C., Frochoso, M., 1998. La alta montaña cantábrica: condiciones térmicas y morfodinámicas en los Picos de Europa. In: Gómez-Ortiz, A., Salvador-Franch, F., Schulte, L., García-Navarro, A. (Editors), Procesos biofísicos actuales en medios fríos. Publicacions de la Universitat de Barcelona, 113-132. 
Castiglioni, G.B., Girardi, A., Sauro, U., Tessari, F., 1979. Grézes Litées e falde detritiche stratificate di origine crionivale. Rivista di Geografia Fisica e Dinamica Quaternaria, 2, 64-82.

Chardon, M., Riser, J., 1981. Formes et processus géomorphologiques dans le Haut-Atlas marocain, Revue de Geographie Alpine, 69, 561-582.

Chelli, A., Pappalardo, M., 2006. Geomorphological mapping, a basic tool for interpreting rock coasts landforms: An example from Eastern Liguria (Italy). Geografia Fisica e Dinamica Quaternaria, 31(1), 13-19.

Chelli, A., Tellini, C., 2002. Geomorphological features of the Bratica Valley (Northern Apennines, Italy). Geografia Fisica e Dinamica Quaternaria, 25(1), 45-60.

Chueca, J., 1992. Análisis geomorfológico de la fenomenología glaciar y periglaciar en el Macizo del Turbón-Sierra de Ballabriga (Pirineo oscense). Instituto de Estudios Altoaragoneses, Huesca, 212 pp.

Chueca, J., Gómez-Ortiz, A., Lampre, F., Peña, J.L., 1994. El periglaciarismo heredado y actual de la cordillera pirenaica y del sistema costero catalán. In: Gómez-Ortiz, A., Simón-Torres, M., Salvador-Franch, F. (Editors), Periglaciarismo en la Península Ibérica, Canarias y Baleares. Sociedad Española de Geomorfología, Universidad de Granada and Servei de Gestió i Evolució del Paisatge de la Universitat de Barcelona, Granada, 93-117.

Chueca, J., Julián, A., 2008. Geomorphological map of the Alta Ribagorza (Central Pyrenees, Spain). Journal of Maps, 4, 235-247.

Chueca, J., Julián, A., Peña, J.L., 2000. El periglaciarismo funcional en las Sierras Exteriores Oscenses. In: Peña, J.L., Sánchez-Fabre, M., Lozano, M.V. (Editors), Procesos y formas periglaciares en la montaña mediterránea. Instituto de Estudios Turolenses, Teruel, 97-112.

Chueca, J., Julián, A., Saz, M.A., Creus J., López, J.I., 2005. Responses to climatic changes since the Little Ice Age on Maladeta Glacier (Central Pyrenees). Geomorphology, 68, 167-82.

Çiçek, İ., Gürgen, G., Tunçel, H., Doğu, A.F., 2006. Doğu Karadeniz dağları'nın glasyal morfolojisi. Proceedings of the symposium of International studies of the Mountainous Areas of Caucasus and Anatolia on Pleistocene and today, 28-42.

Çılğın, Z., 2015. Dedegöl Dağı Kuvaterner buzullaşmaları. Türk Coğrafya Dergisi, 64, 19-37.

Çiner, A., 2003. Türkiye'nin güncel buzulları ve Geç Kuvaterner buzul çökelleri. Türkiye Jeoloji Bülteni, 46(1), 55-78.

Çiner, A., 2004. Turkish glaciers and glacial deposits. In: Ehlers, J., Gibbard, P.L. (Editors), Quaternary Glaciations: Extent and Chronology, Part I: Europe. Elsevier Publishers, Amsterdam, 419-429.

Çiner, A., Deynoux, M., Çörekçioğlu, E., 1999. Hummocky moraines in the Namaras and Susam valleys, Central Taurids, SW Turkey. Quaternary Science Reviews, 18, 4-5, 659-669.

Çiner, A., Sarıkaya, M.A., 2017. Cosmogenic 36Cl Geochronology of late Quaternary glaciers on the Bolkar Mountains, south central Turkey. In: Hughes, P., Woodward, J. (Editors), Quaternary Glaciation in the Mediterranean Mountains, Geological Society of London Special Publications, 433, 271-287.

Çiner, A., Sarıkaya, M.A., Yıldırım, C., 2015. Late Pleistocene piedmont glaciations in the Eastern Mediterranean; insights from cosmogenic $36 \mathrm{Cl}$ dating of hummocky moraines in southern Turkey. Quaternary Science Reviews, 116, 44-56. 
Çiner, A., Sarıkaya, M.A., Yıldırım, C., 2017. Misleading old age on a young landform? The dilemma of cosmogenic inheritance in surface exposure dating: moraines vs. rock glaciers. Quaternary Geochronology, 42, 76-88.

Citterio, M., Turri, S., Perşoiu, A., Bini, A., Maggi, V., 2005. Radiocarbon ages from two ice caves in the Italian Alps and the Romanian Carpathians and their significance. In: Mavlyudov, B.R. (Editor), Glacier Caves and Glacial Karst in High Mountains and Polar Regions, Institute of geography of the Russian Academy of Sciences, Moscow, 87-92.

Clark, P.U., Dyke, A.S., Shakun, J.D., Carlson, A.E., Clark, J., Wohlfarth, B., Mitrovica, J.X., Hostetler, S.W., McCabe, A.M., 2009. The Last Glacial Maximum. Science, 325, 710-714.

Climate Atlas of Croatia 1961-1990, 1971-2000, 2008. Zaninović, K. (Editor), Zagreb, Državni hidrometeorološki zavod, 199 pp.

Coltorti, M., Dramis, F., 1988. The significance of stratified slope-waste deposits in the Quaternary of Umbria-Marche Apennines, central Italy. Zeitschrift fur Geomorphologie, Supplementband, 71, 59-70.

Coltorti, M., Dramis, F., Gentili, B., Pambianchi, G., 1979. Stratified slope waste deposits in the Umbria-Marche Apennines. Proceedings of the 15th Meeting Geomorphological Survey \& Mapping, Modena, 207-212.

Coltorti, M., Dramis, F., Pambianchi, G., 1983. Stratified slope-waste deposits in the Esino River basin, Umbria-Marche Apennines, central Italy. Polarforschung, 53(2), 59-66.

Colucci, R.R., 2016. Geomorphic influence on small glacier response to post Little Ice Age climate warming: Julian Alps, Europe. Earth Surface Processes and Landforms, 41, 1227-1240.

Colucci, R.R., Guglielmin, M., 2015. Precipitation-temperature changes and evolution of a small glacier in the southeastern European Alps during the last 90 years. International Journal of Climatology, 35(10), 2783-2797.

Colucci, R.R., Žebre M., 2016. Late Holocene evolution of glaciers in the southeastern Alps Journal of Maps, 12, 289-299.

Colucci, R.R., Monegato, G., Žebre, M., 2014. Glacial and proglacial deposits of the Resia Valley (NE Italy): new insights on the onset and decay of the last alpine glacial maximum in the Julian Alps. Alpine and Mediterranean Quaternary, 27, 85-104.

Colucci, R.R., Boccali, C., Žebre, M., Guglielmin, M., 2016a. Rock glaciers, protalus ramparts and pronival ramparts in the south-eastern Alps. Geomorphology, 269, 112-121.

Colucci, R.R., Fontana, D., Forte, E., Potleca, M., Guglielmin, M., 2016b. Response of ice caves to weather extremes in the southeastern Alps, Europe. Geomorphology, 261, 1-11.

Colucci, R.R., Luetscher, M., Forte, E., Guglielmin, M., Lanza, D., Princivalle, F., Vita, F., 2017. First alpine evidence of in situ coarse cryogenic cave carbonates (CCCcoarse). Geografia Fisica e Dinamica Quaternaria, 40, 53-59.

Copóns, R., Bordonau, J., 1994. La Pequeña Edad de Hielo en el Macizo de la Maladeta (Alta cuenca del Ésera, Pirineos Centrales). In: Martí-Bono, C., García-Ruiz, J.M. (Editors), El glaciarismo surpirenaico: nuevas aportaciones. Geoforma Ediciones, Zaragoza, 111-124.

Cossart, E., Fort, M., Bourles, D., Carcaillet, J., Perrier, R., Siame, L., Braucher, R., 2010. Climatic significance of glacier retreat and rockglaciers re-assessed in the light of cosmogenic dating and weathering rind thickness in Clarée Valley (Briançonnais, French Alps). Catena, 80(3), 204-219. 
Couvreur, G., 1966. Les formations périglaciaires du Haut Atlas central marocain. Revue de Géographie du Maroc, 10, 47-50.

Cremaschi, M., Zerboni, A., Nicosia, C., Negrino, F., Rodnight, H., Spötl, C., 2015. Age, soilforming processes, and archaeology of the loess deposits at the Apennine margin of the Po plain (northern Italy): New insights from the Ghiardo area. Quaternary International, 376, 173-188.

Ćurić, M., 1996. Climate of Durmitor national park. In: Lješević, M. (Editor), The nature of National Park Durmitor. Geografski fakultet: Beograd, 151-162.

Curran M.A.J., van Ommen, T.D., Morgan, V.I., Phillips K.L., Palmer, A.S., 2003. Ice core evidence for Antarctic sea ice decline since the 1950s. Science, 302(5648), 1203-1206.

Daveau, S., 1973. Quelques exemples d'evolution quaternaire des versants au Portugal. Finisterra, 8, 5-47.

Daveau, S., 1978. Le periglaciaire d'altitude au Portugal. Colloque sur le periglaciaire d'altitude du domaine mediterraneen et ses abords, Estrasburgo, 63-78.

Daveau, S., Ferreira, A.B., Ferreira, N., Vieira, G., 1997. Novas observaçoes sobre aglaciaçao da Serra da Estrela, Portugal. Estudos do Quaternário, 1, 41-51.

De Martonne, E., 1924. Les formes glaciaires sur le versant nord du Haut Atlas, Annales de Géographie, 33, 296-302.

Dede, V., Çiçek, İ., Uncu, L., 2015. Formations of rock glacier in Karçal Mountains, (in Turkish), Bulletin of the Earth Sciences Application and Research Centre of Hacettepe University, 36(2), 61-80.

Dede, V., Çiçek, İ., Sarıkaya, M.A., Çiner, A., Uncu, L., 2017. Late Pleistocene Glaciation in the Lesser Caucasus; Cosmogenic 36Cl geochronology of the Karçal Valley, NE Turkey. Quaternary Science Reviews, 164, 54-67.

Delaloye, R., Perruchoud, E., Avian, M., Kaufmann, V., Bodin, X., Hausmann, H., Ikeda, A., 2008. Recent interannual variations of rock glacier creep in the European Alps. In: Kane, D.L., Hinkel, K.M. (Editors), Proceedings of the 9th International Conference on Permafrost, Fairbanks, USA, 343-348.

Delannoy, J.J., Maire, R., 1983. Le Massif de Dedegöl dag (Taurus Occidental, Turquie). Recherches de géomorphologie glaciaire et karstique. Bulletin de l'Association de Géographie. Française, 491, 43-53.

Delmas, M., 2015. The last maximum ice extent and subsequent deglaciation of the Pyrenees: an overview of recent research. Cuadernos de Investigación Geográfica, 41(2), 359-387.

Denton, G.H., Alley, R.B., Comer, G.C., Broecker, W.S., 2005. The role of seasonality in abrupt climate change. Quaternary Science Reviews, 24, 1159-1182.

Desanges, J., Riser, J., 1989, Atlas, Encyclopédie berbère, 7 - Asarakae - Aurès, Aix-enProvence, Edisud, 1013-1026.

Dewey, J.F., Helman, M.N.L., Turco, E., Hutton, D.H.W., and Knott, S.D.,1989. Kinematics of the western Mediterranean. In: Coward M, (Editor), AlpineTectonics. Geological Society, London, Special Publication, 45, 265-283.

Dimase, A.C., 2006. Fossil cryogenic features in paleosols of southern Italy: Characteristics and paleoclimatic significance. Quaternary International, 156-157, 32-48.

Dimitrov, P., Gikov, A., 2012. Relict rock glaciers identification and mapping in Pirin Mountain using aerial and satellite images. In: Mardirossian, G., Srebrova, T., Jelev, G. (Editors), 
Proceedings of the Seventh Scientific Conference on Space, Ecology, Safety, Sofia, Bulgaria, 256-263.

Djurović P., 2013. The Debeli Namet glacier from the second half of the 20th century to the present. Acta Geographica Slovenica, 52(2), 277-301.

Dobiński, W., 2005. Permafrost of the Carpathian and Balkan Mountains, Eastern and Southeastern Europe. Permafrost and Periglacial Processes, 16, 395-398.

Doğu, A.F., 2009. İhtiyar Şahap Dağları-Van'ın Buzulları, Yeşil Atlas Dergisi, 66-71.

Doğu, A.F., Somuncu, M., Çiçek, İ., Tuncel, H., Gürgen, G., 1993. Kaçkar Dağı'nda buzul şekilleri, yaylalar ve turizm. Ankara Üniversitesi Türkiye Coğrafyası Araştırma ve Uygulama Merkezi Dergisi, 157-183.

Domínguez-Villar, D., Carrasco, R.M., Pedraza, J., Cheng, H., Edwards, R.L., Willenbring, J.K., 2013. Early maximum extent of paleoglaciers from Mediterranean mountains during the last glaciation. Scientific Reports, 3, 20-34.

Dramis, F., Kotarba, A., 1992. Southern limit of relict rock glaciers, Central Apennines, Italy. Permafrost and Periglacial Processes, 3, 257-260.

Dramis, F., Govi, M., Guglielmin, M., Mortara, G., 1995. Mountain permafrost and slope instability in the Italian Alps: The Val Pola Landslide. Permafrost and Periglacial Processes, 6(1), 73-81.

Dramis, F., Giraudi, C., Guglielmin, M., 2003. Rock glacier distribution and paleoclimate in Italy. In: Philips, M., Springman, S.M., Arenson, L.U. (Editors), Permafrost. Taylor \& Francis, London, 199-204.

Dresch, J., 1941. Recherches sur l'evolution du relief dans le Massif Central du Grand Atlas le Haouz et le Sous. Arrault et Cie, Maitres imprimeurs, 653 pp.

Dresch, J., 1949. Sur des formations de remblaiement continental et la presence de forms glaciaires dans le Haut Atlas calcaire. Computes Rendus Somm. Séances Societé Géologique Fr., 9-10, 169-171.

Dresch, J., Raynal, R., 1953. Les formes glaciaires et periglaciaires dans le Moyen Atlas. Comptes Rendus Somm. Seances Societ e Geologique Fr. 11-12, 195-197.

Erinç, S., 1949. Uludă̆ üzerinde glasyal morfoloji araştırmaları. Türk Coğrafya Dergisi, 7994.

Erinç, S., 1951. Glasiyal ve postglasiyal safhada Erciyes glasiyesi. İstanbul Üniversitesi Coğrafya Enstitüsü Dergisi, 1(2), 82-90.

Erinç, S., 1952. Glacial evidences of the climatic variations in Turkey. Geografiska Annaler, Series A, Physical Geography, 34(1-2), 89-98.

Erinç, S., 1953. Van'dan Cilo Dağlarına. Türkiye Coğrafya Bülteni, Ankara Üniversitesi Yayınlar1, 3-4, 84-106. 91-94.

Erinç, S., 1957. Uludağ periglasiyali hakkında. İstanbul Üniv. Coğrafya Enst. Dergisi, 4(8),

Erinç, S., Bilgin, T., Bener, M., 1961. Ilgaz üzerinde periglasiyal şekiller, Türk Coğrafya Dergisi, 12, 151-160.

Evin, M., Fabre, D., 1990. The distribution of permafrost in rock glaciers of Southern Alps (France). Geomorphology, 3, 57-71. 
Evin, M., Assier, A., Fabre, D., 1990. Les glacier rocheux du Marinet, Haut Ubaye, France. Revue de Géomorphologie Dynamique, 4, 139-155.

Evin, M., 1991. Une moraine de refoulement au Viso (Italie). Zeitschrift für Gletscherkunde und Glazialgeologie, 27-28, 11-24.

Favier, L., Durand, G., Cornford, S.L., Gudmundsson, G.H., Gagliardini, O., Gillet-Chaulet, F., Zwinger, T., Payne, A.J., Le Brocq, A.M., 2014. Retreat of Pine Island Glacier controlled by marine ice-sheet instability. Nature Climate Change, 4, 117-121.

Federici, P.R., Ribolini, A., Spagnolo, M., 2017. Glacial History of the Maritime Alps from the Last Glacial Maximum to the Little Ice Age. Geological Society Special Publications, 443(1), 137-159.

Federici, P.R., Granger, D.E., Riobolini, A., Spagnolo, M., Pappalardo, M., Cyr, A.J., 2012. Last glacial Maximum and the Gschnitz stadial in ther Maritime Alps according to $10 \mathrm{Be}$ cosmogenic dating. Boreas, 41, 277-291.

Fernandes, M., Oliva, M., Palma, P., Ruiz-Fernández, J., Lopes, L., 2017. Glacial stages and post-glacial environmental evolution in the Upper Garonne valley, Central Pyrenees. Science of the Total Environment, 584, 1282-1299.

Fernández-Fernández J.M., Palacios D., García-Ruiz, J.M., Andrés, N., Schimmelpfennig, I., Gómez-Villar, A., Santos-González, J., Álvarez-Martínez, J., Arnáez, J., Úbeda, J., Léanni, L., ASTER Team., 2017. Age and geomorphological context of fossil debris-covered glaciers in relation to deglaciation processes: a case study in the Sierra de la Demanda, Northern Spain. Quaternary Science Reviews, 170, 232-249.

Ferreira, A.B., Rodrigues, M.L., Vieira, G.T., 2000. Manifestaçoes herdadas e actuais de climas frios em Portugal. In: Peña, J.L., Sánchez- Fabre, M., Lozano, M.V. (Editors), Procesos y formas periglaciares en la montaña mediterránea. Instituto de Estudios Turolenses, Teruel, 161190.

Feuillet, T., 2010. Les formes périglaciaires dans les Pyrénées centrales francaises: analyse spatiale, chronologique et valorisation. PhD Thesis, University of Nantes.

Feuillet, T., Mercier, D., 2012. Post-Little Ice Age patterned ground development on two Pyrenean proglacial areas: from deglaciation to periglaciation. Geografiska Annaler, Series A, Physical Geography, 94, 363-376.

Finsinger, W., Tinner, W., 2006. Holocene vegetation and land-use changes in response to climatic changes in the forelands of the southwestern Alps, Italy. Journal of Quaternary Science, 21(3), 243-258

Fioraso, G., Spagnolo, G., 2009. I block stream del Massiccio Peridotitico di Lanzo (Alpi nordoccidentali). Il Quaternario, 22(1), 3-22.

Firpo, M., Guglielmin, M., Queirolo, C., 2006. Relict blockfields in the Ligurian Alps (Mount Beigua, Italy). Permafrost and Periglacial Processes, 17, 71-78.

Fletcher, W.J., Sánchez-Goñi, M.F., Peyron, O., Dormoy, I., 2010. Abrupt climate changes of the last deglaciation detected in a Western Mediterranean forest record. Climate of the Past, 6, 245-264.

Fotiadi, A.K., Metaxas, D.A., Bartzokas, A., 1999. A statistical study of precipitation in northwest Greece. International Journal of Climatology, 19, 1221-1232.

Francou, B., Reynaud, L., 1992. 10-year surficial velocity on a rock glacier (Laurichard, French Alps). Permafrost Periglacial Processes, 3, 209-213. 
Frauenfelder, R., Haeberli, W., Hoelzle, M., Maisch, M., 2001. Using relict rockglaciers in GIS-based modelling to reconstruct Younger Dryas permafrost distribution patterns in the errJulier area, Swiss Alps. Norsk Geografisk Tidsskrift, 55, 195-202.

French, H.M., 2007. The periglacial environment. John Wiley \& Sons, Third Edition. Chichester, England.

Frenzel, B., Pecsi, B., Velichko, A.A., 1992. Atlas of Palaeoclimates and Palaeoenvironments of the Northern Hemisphere. Budapest: INQUA/Hungarian Academy of Sciences.

Frezzotti, M., Giraudi, C., 1992. Late Pleistocene and Holocene geological evolution of the Majelama Valley alluvial fan (Velino Massi, Abruzzo). Alpine and Mediterranean Quaternary, 5(1), 33-50.

Fritz, M., Vonk, J.E., Lantuit, H., 2017. Collapsing Arctic coastlines. Nature Climate Change, 7(1), 6-7.

Gachev E., Stoyanov K., 2012. Present day small prerennial firn-like patches in the mountains of the western Balkan Peninsula. Studia geomorphologica Carpatho-Balcanica, vol. XLVI, 5170 .

Gachev, E., Stoyanov, K., Gikov, A., 2016. Small glaciers on the Balkan Peninsula: State and changes in the last several years. Quaternary International, 415, 33-54.

García de Celis, A., 1991. Los glaciares rocosos de la Sierra del Suspirón (León). Polígonos, $1,9-20$.

García de Celis, A., 2002. Formas periglaciares relictas en la Sierra de Suspirón (Cordillera Cantábrica, León): campos de bloques. In: Serrano, E., García de Celis, A. (Editors), Periglaciarismo en montaña y altas latitudes, Universidad de Valladolid, Valladolid, 37-52.

García-Ruiz, J.M., 1979. El glaciarismo cuaternario en la Sierra de la Demanda (LogroñoBurgos, España). Cuadernos de Investigación. Geografía e Historia, 5(2), 3-25.

García-Ruiz, J.M., Martí-Bono, C., 2001. Mapa geomorfológico del Parque Nacional de Ordesa y Monte Perdido. Ministerio de Medio Ambiente, Madrid, 106 pp.

García-Ruiz, J.M., Alvera, B., del Barrio, G., Puigdefábregas, J., 1988. Geomorphic processes above the timberline in the Spanish Pyrenees. Mountain Research and Developement, 10(3), 201214.

García-Ruiz, J.M., Ortigosa, L., Pellicer, F., Arnáez, J., 1998. Geomorfología glaciar del Sistema Ibérico. In: Gómez-Ortiz, A., Pérez-Alberti, A. (Editors), Las huellas glaciares de las montañas españolas. Universidad de Santiago de Compostela, 347-381.

García-Ruiz, J.M., Beguería, S., Lorente, A., 2000. Eventos hidrológicos de baja frecuencia en el Pirineo Central español y sus efectos geomorfológicos. Serie Geográfica, 9, 163-176.

García-Ruiz, J.M., Gómez-Villar, A., Ortigosa, L., Martí-Bono, C., 2000. Morphometry of glacial cirques in the Central Spanish Pyrenees. Geografiska Annaler. Series A, Physical Geography, 82(4), 433-442.

García-Ruiz, J.M., Martí-Bono, C., Valero B., González-Sampériz, P., 2005. Central Spanish Pyrenees: glacial and periglacial landforms. Proceedings of the Sixth International Conference on Geomorphology, Field trip guides t-1, SEG-University of Zaragoza, 311-340.

García-Ruiz, J.M., Moreno, A., González-Sampériz, P., Valero-Garcés, B., Martí-Bono, C., 2010. La cronología del último ciclo glaciar en las montañas del sur de Europa. Una revisión. Cuaternario \& Geomorfología, 24(1-2), 35-46. 
García-Ruiz, J.M., Palacios, D., de Andrés, N., Valero-Garcés, B.L., López-Moreno, J.L., Sanjuán, Y., 2014. Holocene and Little Ice Age glacial activity in the Marboré cirque, Monte Perdido Massif, Central Spanish Pyrenees. The Holocene, 24(11), 1439-1452.

García-Ruiz, J.M., López-Moreno, J.I., Lasanta, T., Vicente-Serrano, S.M., GonzálezSampériz, P., Valero-Garcés, B.L., Sanjuán, Y., Beguería, S., Nadal-Romero, E., Lana-Renault, N., Gómez-Villar, A., 2015. Los efectos geoecológicos del cambio global en el Pirineo Central español: una revisión a distintas escalas espaciales y temporales. Pirineos, 170, e012.

García-Ruiz, J.M., Palacios, D., González-Sampériz, P., Andrés, N., Moreno, A., ValeroGarcés, B., Gómez-Villar, A., 2016a. Mountain glacier evolution in the Iberian Peninsula during the Younger Dryas. Quaternary Science Reviews, 138, 16-30.

García-Ruiz, J.M., Palacios, D., González-Sampériz. P., de Andrés, N., Moreno, A., ValeroGarcés, B., Gómez-Villar, A., 2016b. Evidencias de actividad glaciar durante el Dryas Reciente (12,9-11,7 ka BP) en la Península Ibérica. Cuaternario y Geomorfología, 30(1-2), 9-21.

García-Ruiz, J.M., Valero-Garcés, B.L., Martí-Bono, C., González-Sampériz, P., 2003. Asynchroneity of maximum glacier advances in the central Spanish Pyrenees. Journal of Quaternary Science, 18, 61-72.

Gellatly, A.F., Grove, J.M., Switsur, V.R., 1992. Mid Holocene glacial activity in the Pyrenees. The Holocene, 2(3), 266-270.

Genxu, W., Yuanshou, L., Qingbai, W., Yibo, W., 2006. Impacts of permafrost changes on alpine ecosystem in Qinghai-Tibet Plateau. Science in China Series D: Earth Sciences, 49(11), 1156-1169.

Ghuma M.A., Rogers, J.J.W., 1978. Geology, geochemistry, and tectonic setting of the Ben Ghnema batholith, Tibesti massif, southern Libya. Geological Society of America, 89, 13511358.

Gianotti, F., Forno, M.G., Ivy-Ochs, S., Kubik, P.W., 2008. New chronological and stratigraphical data on the Morainic Amphiteatre of Ivrea (Piedmont, NW Italy). Quaternary International, 190(1), 123-135.

Gikov, A., Dimitrov, P., 2011. Relict rock glaciers identification and mapping in Rila mountain using aerial and satellite images. In: Mardirossian, G., Srebrova, T., Jelev, G. (Editors), Proceedings of the Sixth Scientific Conference on Space, Ecology, Safety, Sofia, Bulgaria, 252259.

Ginesu, S., 1990. Periglacial deposits in Sardinia: the blockstreams near Pranu Mannu. Geografia Fisica e Dinamica Quaternaria 13(2), 179-181.

Ginesu, S., Sias, S., 2006. La Sardegna. In: Chelli, A., D’Aquila, P., Firpo, M., Ginesu, S., Guglielmin, M., Pappalardo, M., Pecci, M., Piacentini, T., Queirolo, C., Robustelli, G., Scarciglia, F., Sias, S., Tellini, C. (Editors), Testimoni di una montagna scomparsa. Contributo alle metodologie d'indagine delle forme periglaciali relitte. Problematiche e applicazioni in differenti ambienti morfodinamici. Collana «Quaderni della Montagna», vol. 8, Bologna: Bonomia University Press, 73-80.

Ginesu, S., Carboni, D., Congiatu, P.P., 2014. Relict forms of disappeared mountain. The periglacial deposits in Asinara Island-Sardinia (Italy). Journal of Environmental and Tourism Analyses, 2(1), 19-32.

Giraudi, C., 1998. Late Pleistocene and Holocene lake level variations in Fucino Lake (Abruzzo - Central Italy) inferred from geological, archaeological and historical data. Palaoklimaforschung- Palaeoclimate Research, 25, 1-18. 
Giraudi, C., 2002. I rock glacier tardo-pleistocenici ed oloceni dell'appennino: età, distribuzione, significato paleoclimatico. Alpine and Mediterranean Quaternary, 15(1), 45-52.

Giraudi, C., 2003. Middle Pleistocene to Holocene Apennine glaciations (Italy). Alpine and Mediterranean Quaternary, 16(1), 37-48.

Giraudi, C., 2004. The Apennine glaciations in Italy. Developments in Quaternary Science, 2(1), 215-223.

Giraudi, C., 2012. The Campo Felice late Pleistocene Glaciation (Apennines, central Italy). Journal of Quaternary Science, 27(4), 432-440.

Giraudi, C., 2015. The Upper Pleistocene deglaciation on the Apennines (Peninsular Italy). Cuadernos de Investigación Geográfica, 41(2), 87-105.

Giraudi, C., Frezzotti, M., 1997. Late Pleistocene glacial events in the Central Apennines, Italy. Quaternary Research, 48(3), 280-290.

Giraudi, C., Magny, M., Zanchetta, G., Drysdale, R.N., 2011. The Holocene climatic evolution of Mediterranean Italy: A review of the continental geological data. The Holocene, 21(1), 105115 .

Gómez, F., Allmendinger, R., Barazangi, M., Beauchamp, W., 2000. Role of the Atlas Mountains (northwest Africa) within the African-Eurasian plate boundary zone. Geology, 28, 769-864.

Gómez-Lende M., 2015. Las cuevas heladas en Picos de Europa: clima, morfologías y dinámicas. $\mathrm{PhD}$ thesis, University of Valladolid.

Gómez-Lende, M., Berenguer, F., Serrano, E., 2014. Morphology, ice types and thermal regime in a high mountain ice cave. First studies applying terrestrial laser scanner in the Peña Castil Ice Cave (Picos de Europa, Northern Spain). Geografia Fisica e Dinamica Quaternaria, 37, 141-150.

Gómez-Ortiz, A., 1980. Estudio geomorfológico del Pirineo catalán: morfogénesis glacial y periglacial de los altos niveles y vertientes merdionales de los macizos de Calmquerdós, Tossa Plana de Llés y Port Negre (Cerdanya-Alt Urgell). PhD thesis, University of Barcelona.

Gómez-Ortiz, A., 1987. Morfología glaciar en la vertiente meridional de Sierra Nevada (área Veleta-Mulhacén). Estudios Geográficos, 193, 527-558.

Gómez-Ortiz, A., Serrat, D., 1977. Las formaciones geométricas periglaciares de los altos niveles del Pirineo Oriental. V Coloquio de Geografía. Universidad de Granada, Granada, 75-81.

Gómez-Ortiz, A., Salvador-Franch, F., 1992. Aportaciones significativas al conocimiento del glaciarismo y periglaciarismo de Sierra Nevada. Notes de Geografía Física, 20-21, 89-101.

Gómez-Ortiz, A., Díaz del Olmo, F., Simón-Torres, M., 1994. Periglaciarismo en las Cordilleras Béticas. In: Gómez-Ortiz, A., Simón-Torres, M., Salvador-Franch, F. (Editors), Periglaciarismo en la Península Ibérica, Canarias y Baleares. Estudios significativos, SEGUniversidad de Granada, Granada, 165-188.

Gómez-Ortiz, A., Palacios, D., Ramos, M., Tanarro, L.M., Schulte, L., Salvador, F., 2001. Location of permafrost in marginal regions: Corral del Veleta, Sierra Nevada, Spain. Permafrost and Periglacial Processes, 12, 93-110.

Gómez-Ortiz, A., 2002. Mapa geomorfológico de Sierra Nevada. Consejería de Medio Ambiente de la Junta de Andalucía, Granada. 
Gómez-Ortiz, A., Palacios, D., Ramos, M., 2004. Permafrost, evolution of associated landforms and thermal control in the Veleta Cirque (Sierra Nevada, Spain). New results. Boletín de la Real Sociedad Española de Historia Natural, 99(1-4), 47-63.

Gómez-Ortiz, A., Plana Castellví, J.A., 2006. La Pequeña Edad del Hielo en Sierra Nevada a partir de los escritos de la época (siglos XVIII y XIX) y relaciones con el progreso de la geografía física y geomorfología española. Boletín de la Asociación de Geografos Españoles, 42, 71-98.

Gómez-Ortiz, A., Palacios, D., Schulte, L., Salvador-Franch, F., Plana, J.A., 2009. Evidences from historical documents of landscape evolution after Little Ice Age of a Mediterranean high mountain area, Sierra Nevada, Spain (eighteenth to twentieth centuries). Geografiska Annaler, Series A, Physical Geography, 91, 279-289.

Gómez-Ortiz, A., Palacios, D., Palade, B., Vázquez-Selem, L., Salvador-Franch, F., 2012a. The deglaciation of the Sierra Nevada (Southern Spain). Geomorphology, 159-160, 93-105.

Gómez-Ortiz, A., Salvador-Franch, F., Sanjosé, J.J., Palacios, D., Oliva, M., Salvà, M., Tanarro, L., Raso, J., Atkinson, A., Schulte, L., Plana, J., Milheiro, B., Serrano, D., 2012b. Degradación de hielo fósil y permafrost y cambio climático en Sierra Nevada. In: Ramírez, L., Asensio, B. (Editors), Proyectos de investigación en parques nacionales: 2008-2011. Colección Naturaleza y Parques Nacionales. Organismo Autónomo Parques Nacionales, Ministerio de Agricultura, Alimentación y Medio Ambiente. Madrid, 25-43.

Gómez-Ortiz, A., Palacios, D., Palade, B., Vázquez-Selem, L., Salvador, F., Tanarro, L., Oliva, M., 2013. La evolución glaciar de Sierra Nevada y la formación de glaciares rocosos. Boletín de la Asociación de Geógrafos Españoles, 61, 139-162.

Gómez-Ortiz, A., Oliva, M., Salvador, F., Salvà, M., Palacios, D., Sanjosé, J.J., Tanarro, L., Galindo-Zaldívar, J., Sanz de Galdeano, C., 2014. Degradation of buried ice and permafrost in the Veleta cirque (Sierra Nevada, Spain) from 2006-2013. Solid Earth, 5, 979-993.

Gómez-Ortiz, A., Oliva, M., Palacios, D., Salvador-Franch, F., Vázquez-Selem, L., SalvàCatarineu, M., de Andrés, N., 2015. The deglaciation of Sierra Nevada (Spain), synthesis of the knowledge and new contributions. Cuadernos de Investigación Geográfica, 41(2), 409-426.

Gómez-Villar, A., González-Gutiérrez, R.B., Redondo, J.M., Santos, J., 2011. Distribución de glaciares rocosos relictos en la Cordillera Cantábrica. Cuadernos de Investigación Geográfica, 37(2), 49-80.

González-García, M., 2014. La alta montaña periglaciar en el Pirineo Central español. Procesos, formas y condiciones ambientales. PhD thesis, University of Málaga.

González-García, M., Serrano, E., Sanjosé, J.J., González-Trueba, J.J., 2017. Surface dynamic of a protalus lobe in the temperate high mountain, Western Maladeta, Pyrenees. Catena, 149(3), 689-700.

González-Gutiérrez, R.B., 2002. El relieve de los valles del Torío y Curureño (Montaña Cantábrica Leonesa). University of León.

González-Sampériz, P., Moreno, A., 2013. Glacial and fluvial deposits in the Aragón Valley, central-western Pyrenees: chronology of the Pyrenean late Pleistocene glaciers. Geografiska Annaler: Series A, Physical Geography, 95, 15-32.

González-Trueba, J.J., 2006. Topoclimatical factors and very small glaciers in Atlantic mountain of SW Europe: Little Ice Age glacial advance in Picos de Europa (NW Spain). Zeitschrift fur Gletscherkunde und Glazialgeologie, 39, 115-125. 
González-Trueba, J.J., 2007a. El paisaje natural del Macizo Central de los Picos de Europa: Geomorfología y sus implicaciones geoecológicas en la alta montaña cantábrica. CIMA-Medio Ambiente de Cantabria, Santander.

González-Trueba, J.J., 2007b. Geomorfología del macizo central del Parque Nacional de Picos de Europa. OAPN-Ministerio de Medio Ambiente, Madrid.

González-Trueba, J.J., Martín, R., Martínez de Pisón, E., Serrano, E., 2008. Little Ice Age and current glaciers, Iberian Peninsula. The Holocene, 18, 551-568.

Gorbunov, A.P., 2012. Rock glaciers, kurums, glaciers and permafrost in the mountains of Turkey (Geographical review). Earth Cryosphere, 16, 2, 3-8.

Greenwood, S.L., O’Regan, M., Swärd, H., Flodén, T., Ananyev, R., Chernykh, D., Jakobsson, M., 2015. Multiple re-advances of a Lake Vättern outlet glacier during Fennoscandian Ice Sheet retreat, south-central Sweden. Boreas, 44(4), 619-637.

Grove, J.M., 2004. Little Ice Ages: Ancient and Modern. Routledge, London (2 volumes).

Grove, J.M., Gellatly, A.F., 1995. Little Ice Age fluctuations in the Pyrenees. Zeitschrift für Gletcherkunde und Glacialgeologie, 31, 199-206.

Gruber, S., 2012. Derivation and analysis of a high-resolution estimate of global permafrost zonation. The Cryosphere, 6, 221-233.

Gruber, S., Hoelzle, M., Haeberli, W., 2004. Permafrost thaw and destabilization of Alpine rock walls in the hot summer of 2003. Geophysical Research Letters, 31, 13, 504.

Grünewald, K., Scheithauer, J., 2008. Bohrung in einen Mikrogletscher. Zeitschrift für Gletscherkunde und Glazialmorphologie, 42, 3-18.

Grunewald, K., Scheithauer, J., 2010. Europe's southernmost glaciers: response and adaptation to climate change. Journal of Glaciology, 42, 3-18.

Grünewald, K., Scheitchauer, J., Gikov, A., 2008. Microglaciers in the Pirin Mountains (Mikrolednitsi v Pirin Planina). Problems of Geography, Bulgarian Academy of Sciences, 1-2.

Guglielmin, M., Smiraglia, C. (Editors), 1997. Catasto dei rock glaciers delle Alpi Italiane. Archivio Comitato Glaciologico Italiano, 3, 1-103.

Guglielmin, M., Lozej, A., Tellini, C., 1994. Permafrost distribution and rock glaciers in the Livigno area (northern Italy). Permafrost and Periglacial Processes, 5, 1-12.

Guglielmin, M., Cannone, N, Dramis, F., 2001. Permafrost-glacial evolution during the Holocene in the Italian Central Alps. Permafrost and Periglacial Processes, 12, 111-124.

Guglielmin, M., Cannone, N, Strini, A, Lewkowicz, A., 2005. Biotic and abiotic processes on granite weathering landforms in a cryotic environment, Northern Victoria Land, Antarctica. Permafrost and Periglacial Processes, 16, 69-85.

Guglielmin, M., Dalle Fratte, M., Cannone, N., 2014. Permafrost warming and vegetation changes in continental Antarctica. Environmental Research Letters, 9, 045001.

Gürgen, G., 2001. Karadağ (Gümüşhane) çevresinin glasyal morfolojisi ve turizm potansiyeli. AÜ Türkiye Coğrafyası Dergisi, 8, 109-132.

Gürgen, G., Yeşilyurt, S., 2012. Karçal Dağı Buzulları (Artvin). Coğrafi Bilimler Dergisi, 10(1), 91-104.

Gürgen, G., Çalışkan, O., Yılmaz, E., Yeşilyurt, S., 2010. Yedigöller platosu ve Emli vadisinde (Aladağlar) döküntü örtülü buzullar, E-Journal of New World Sciences Academy, NEWSSA, (www.newwsa.com), 5, 98-116. 
Gutierrez, M., Peña, J.L., 1977. Las acumulaciones periglaciares del Macizo del Tremedal (Sierra de Albarracín). Boletín Geológico y Minero, 88(2), 109-115.

Haeberli, W., 1985. Creep of mountain permafrost: internal structure and flow of alpine rock glaciers. Mitteilungen der Versuchsanstalt Conference with International Participation Space, 77, $142 \mathrm{pp}$.

Haeberli, W., Beniston, M., 1998. Climate change and its impacts on glaciers and permafrost in the Alps. Ambio, 27(4), 258-265.

Hagedorn J., 1969. Beiträge zur Quartärmorphologie griechischer Hochgebirge. Göttinger Geographische Abhandlungen, 50, 135 pp.

Hall-Riaza, J.F., Valcárcel, M., Blanco-Chao, R., 2016. Caracterización morfométrica de formas glaciares en cuña en las Sierras de Xistral, Teleno y Cabrera. Polígonos. Revista de Geografía, 28, 55-71.

Hannah, G., Hughes, P.D., Gibbard, P. L., 2017. Pleistocene plateau ice fields in the High Atlas, Morocco. In: Hughes, P., Woodward, J. (Editors), Quaternary Glaciation in the Mediterranean Mountains, Geological Society of London Special Publications, 433, 25-53.

Harris, C., Vonder-Mühll, D., Isaksen, K., Haeberli, W., Sollid, J.L., King, L., Holmlund, P., Dramis, F., Guglielmin, M., Palacios, D., 2003. Warming permafrost in European mountains. Global and Planetary Change, 39(3-4), 215-225.

Hausmann, H., Behm, M., 2011. Imaging the structure of cave ice by ground penetrating radar. The Cryosphere, 5, 329-340.

Heinrich, 1988. Origin and consequences of cyclic ice rafting in the Northeast Atlantic Ocean during the past 130,000 years. Quaternary Research, 29(2), 142-152.

Hemming, S.R., 2004. Heinrich events: Massive late Pleistocene detritus layers of the North Atlantic and their global climate imprint. Reviews of Geophysics, 42(1), 1-43.

Hempel, L., 1991. Forschungen zur Physischen Geographie der Insel Kreta im Quartär. Ein Beitrag zur Geoökologie des Mittelmeerraumes. Vandenhoeck \& Ruprecht in Göttingen.

Hijmans, R.J., S.E. Cameron, J.L. Parra, P.G., Jarvis, A., 2005. Very high resolution interpolated climate surfaces for global land areas. International Journal of Climatology, 25, 1965-1978.

Hippolyte, J.C., Bourlès, D., Braucher, R., Carcaillet, J., Léanni, L., Arnold, M., Aumaitre, G., 2009. Cosmogenic 10Be dating of a sackung and its faulted rock glaciers, in the Alps of Savoy (France). Geomorphology, 108, 312-320.

Hirsch, F., Raab, T., 2014. Geophysical prospection on Late Quaternary sediments in the Gállego Valley, Central Spanish Pyrenees. Zeitschrift für Geomorphologie, 58, 47-62.

Hoelzle, M., 1992. Permafrost occurrence from BTS measurements and climatic parameters in the eastern Swiss Alps. Permafrost and Periglacial Processes, 3(2), 143-147.

Hoelzle, M., 1996. Mapping and modelling of mountain permafrost distribution in the Alps. Norwegian Journal of Geography, 50, 11-15.

Höllermann, P., 1985. The periglacial belt of midlatitude mountains from a geoecological point of view. Erdkunde 39, 259-270.

Holmlund, P., Onac, B.B., Hansson, M., Holmgren, K., Mörth, M., Nyman, M., Perşoiu, A., 2005. Assessing the palaeoclimatic potential of cave glaciers: the example of the Scarisoara Ice Cave (Romania). Geografiska Annaler, Series A, Physical Geography, 87(1), 193-201. 
Hugelius, G., Strauss, J., Zubrzycki, S., Harden, J.W., Schuur, E.A.G., Ping, C.L., Schirrmeister, L., Grosse, G., Michaelson, G.J., Koven C.D., O’Donnell, J.A., Elberling, B., Mishra, U., Camill, P., Yu, Z., Palmtag, J., Kuhry, P., 2014. Estimated stocks of circumpolar permafrost carbon with quantified uncertainty ranges and identified data gaps. Biogeosciences, 11, 6573-6593.

Hughes, A.L.C., Gyllencreutz, R., Lohne, Ø. S., Mangerud, J., Svendsen, J. I., 2016. The last Eurasian ice sheets - a chronological database and time-slice reconstruction, DATED-1. Boreas, $45(1), 1-45$.

Hughes, P.D., 2004. Quaternary Glaciation in the Pindus Mountains, Northwest Greece. Ph.D. thesis, University of Cambridge, $341 \mathrm{pp}$.

Hughes, P.D., 2008. Response of a Montenegro glacier to extreme summer heatwaves in 2003 and 2007. Geografiska Annaler, Series A, Physical Geography, 192, 259-267.

Hughes, P.D., 2009. Twenty-first Century Glaciers and Climate in the Prokletije Mountains, Albania. Arctic Antacrtic and Alpine Research, 41, 455-459.

Hughes, P.D., 2010. Little Ice Age glaciers in the Balkans: Low altitude glaciation enabled by cooler temperatures and local topoclimatic controls. Earth Surface Processes and Landforms, 35, 229-241.

Hughes, P.D., 2014. Little Ice Age glaciers on the Mediterranean mountains. Mediterranée. $112,63-79$.

Hughes, P.D., 2018. Little Ice Age glaciers and climate in the Mediterranean mountains: a new analysis. Cuadernos de Investigación Geográfica, 44, 15-46.

Hughes, P.D., Gibbard, P.L. 2015. A stratigraphical basis for the Last Glacial Maximum (LGM). Quaternary International, 383, 174-185.

Hughes, P.D., Woodward, J.C., 2008. Timing of glaciation in the Mediterranean mountains during the last cold stage. Journal of Quaternary Science, 23(6-7), 575-588.

Hughes, P.D., Woodward, J.C., 2009. Glacial and periglacial environments. In: Woodward, J.C. (Editor), The Physical Geography of the Mediterranean. Oxford University Press, Oxford, 353-383.

Hughes, P.D., Woodward, J., 2017. Quaternary glaciation in the Mediterranean mountains: a new synthesis. In: Hughes, P., Woodward, J.C., (Editors), Quaternary Glaciation in the Mediterranean Mountains, Geological Society of London Special Publication, 433, 1-23.

Hughes, P.D., Gibbard, P.L., Woodward, J.C., 2003. Relict rock glaciers as indicators of Mediterranean palaeoclimate during the Last Glacial Maximum (Late Würmian) in northwest Greece. Journal of Quaternary Science, 18, 431-440.

Hughes, P.D., Gibbard, P.L., Woodward, J.C., 2004. Quaternary glaciation in the Atlas mountains, North Africa. In: Ehlers, J., Gibbard, P.L. (Editors), Quaternary Glaciations: Extent and Chronology, Volume 3: Asia, Latin America, Africa, Australia, Antarctica. Elsevier Publishers, Amsterdam, 255-260.

Hughes, P.D., Woodward, J.C., Gibbard, P.L., 2006a. Quaternary glacial history of the Mediterranean mountains. Progress in Physical Geography, 30(3), 334-364.

Hughes, P.D., Woodward, J.C., Gibbard, P.L., 2006b. Late Pleistocene glaciers and climate in the Mediterranean region. Global and Planetary Change, 50(1-2), 83-98. 
Hughes, P.D., Woodward, J.C., Gibbard, P.L., 2007. Middle Pleistocene cold stage climates in the Mediterranean: new evidence from the glacial record. Earth and Planetary Science Letters, $253,50-56$.

Hughes, P.D., Woodward, J.C., van Calsteren, P.C., Thomas, L.E., Adamson, K.R., 2010. Pleistocene ice caps on the coastal mountains of the Adriatic Sea. Quaternary Science Reviews, 29, 3690-3708.

Hughes, P. D., Fenton, C.R., Gibbard, P. L., 2011. Quaternary Glaciations of the Atlas Mountains, North Africa, in: Developments in Quaternary Science, Elsevier, USA, 15, 10651074.

Hughes, P.D., Woodward, J.C., van Calsteren, P.C., Thomas, L.E., 2011. The glacial history of the Dinaric Alps, Montenegro. Quaternary Science Reviews, 30, 3393-3412.

Hughes, P.D., Gibbard, P.L., Ehlers, J., 2013. Timing of glaciation during the last glacial cycle: evaluating the concept of a global "Last Glacial Maximum" (LGM). Earth Science Reviews, 125, 171-198.

Hughes, P.D., Fink, D., Fletcher, W.J., Hannah, G., 2014. Catastrophic rock avalanches in a glaciated valley of the High Atlas, Morocco: ${ }^{10} \mathrm{Be}$ exposure ages reveal a $4.5 \mathrm{ka}$ seismic event. Geological Society of America Bulletin 126, 1093-1104.

Hughes, P.D., Glasser, N.F., Fink, D., 2016. Rapid thinning of the Welsh Ice Cap at 20-19 ka based on ${ }^{10} \mathrm{Be}$ ages. Quaternary Research 85, 107-117.

Hughes, P.D., Fink, D., Rodés, Á., Fenton, C. R., Fujiyoka, T., 2018. Timing of Pleistocene glaciations in the High Atlas, Morocco: New ${ }^{10} \mathrm{Be}$ and ${ }^{36} \mathrm{Cl}$ exposures ages. Quaternary Science Reviews, 180, 193-213.

Ikeda, A., Matsuoka, N., 2002. Degradation of talus-derived rock glaciers in the Upper Engadin, Swiss Alps. Permafrost and Periglacial Processes, 13(2), 145-161.

Ilyashuk, E.A., Koinig, K.A., Heiri, O., Ilyashuk, B.P., Psenner, R., 2011. Holocene temperature variations at a high-altitude site in the Eastern Alps: A chironomid record from Schwarzsee ob Sölden, Austria. Quaternary Science Reviews, 30(1-2), 176-191.

IPCC Climate Change 2013, 2013. The Physical Science Basis. Contribution of Working Group I to the Fifth Assessment Report of the Intergovernmental Panel on Climate Change. Cambridge University Press, Cambridge, 1535 pp.

Ivy-Ochs, S., 2015. Glacier variations in the European Alps at the end of the Last Glaciation. Cuadernos de Investigación Geográfica, 4(2), 295-315.

Ivy-Ochs, S., Schäffer, J., Kubik, P.W., Synal, H.N., Schlüchter, C., 2004. Timing of deglaciation on the northern Alpine foreland (Switzerland). Eclogae Geologicae Helvetiae, 97, 47-55.

Ivy-Ochs, S., Kerschner, H., Reuther, A., Preusser, F., Heine, K., Maisch, M., Kubik, P.W., Schlüchter, C., 2008. Chronology of the last glacial cycle in the European Alps. Journal of Quaternary Science, 23, 559-573.

Ivy-Ochs, S., Kerschner, H., Maisch, M., Christl, M., Kubik, P.W., Schlüchter, C., 2009. Latest Pleistocene and Holocene glacier variations in the European Alps. Quaternary Science Reviews, 28(21-22), 2137-2149.

İzbırak, R., 1951. Cilo Dağı ve Hakkari ile Van Gölü çevrelerinde coğrafya araştırmaları, Ankara Üniversitesi Dil Tarih Coğrafya Fakültesi yayınları, 67(4), 149. 
Jeftic, L., Bernhard, M., Demetropoulos, A., Fernex, F., Gabrielides, G.P., Gasparovic, F., Halim, Y., Orhon, D., Saliba, L.J., Fukai, R., 1989. State of the Mediterranean Marine Environment. MAP Technical Reports Series No. 28. UNEP, Athens.

Jiménez, M., Farias, P., 2002. New radiometric and geomorphologic evidences of a Last Glacial Maximum older than $18 \mathrm{ka}$ in SW European mountains: the example of Redes Natural Park (Cantabrian Mountains, NW Spain). Geodinamica Acta, 15, 93-101.

Jiménez, M., Rodríguez-Rodríguez, L., García-Ruiz, J.M., Domínguez-Cuesta, M.J., Farias, P., Valero-Garcés, B., Moreno, A., Rico, M., Valcárcel, M., 2013. A review of glacial geomorphology and chronology in northern Spain: timing and regional variability during the last glacial cycle. Geomorphology, 196, 50-64.

Joly, F., 1962. Etude sur le relief du Sud-Est morocain: Rabat, Travaux Institut Scientifique Chérifien, série géologie et géographie physique, 10, 578 pp.

Jorgenson, M.T., Osterkamp, T.E., 2005. Response of boreal ecosystems to varying modes of permafrost degradation. Canadian Journal of Forest Research, 35(9), 2100-2111.

Jorgenson, M.T., Racine, C.H., Walters, J.C., Osterkamp, T.E., 2001. Permafrost degradation and ecological changes associated with a warming climate in Central Alaska. Climatic Change, 48(4), 551-579.

Joughin, I., Smith, B.E., Holland, D.M., 2010. Sensitivity of 21st century sea level to oceaninduced thinning of Pine Island Glacier, Antarctica. Geophysical Research Letters, 37, L20502.

Julián, A., Chueca, J., 1998. Le Petit Âge Glaciaire dans les Pyrénées Centrales Meridionales: estimation des paléotempératures á partir d'inférences géomorphologiques. Sud-Ouest Europeen. $3,79-88$.

Julián, A., Chueca, J., 2007. Permafrost distribution from BTS measurements (Sierra de Telera, Central Pyrenees, Spain): assessing the importance of solar radiation in a mid-elevation shaded mountainous area. Permafrost and periglacial Processes, 18(2), 137-149.

Slovenian Cave Registry, 2014. Jointly managed by Speleological Association of Slovenia and Karst Research Institute of the Slovenian Academy of Science and Arts.

Kern, Z., Surányi, G., Molnár, M., Nagy, B., Balogh, D., 2006a. Investigation of natural perennial ice deposits of Durmitor Mts, Montenegro. In: Zelinka, J. (Editor), Proceedings of the 2nd international workshop on ice caves, Demänovská dolina, Slovak Republic, 70-73.

Kerschner, H., Ivy-Ochs, S., 2008. Paleoclimate from glaciers: examples from the Eastern Alps during the Alpine Lateglacial and early Holocene. Global and Planetary Change, 60, 58-71.

Kesici, O., 2005. Küresel ısınma çerçevesinde Süphan ve Cilo dağlarında buzul morfolojisi araştırmaları. TÜBİTAK proje raporu No: 101Y131.

King, L., Akerman J., 1993. Mountain permafrost in Europe. In: Proceedings of the Sixth International Conference on Permafrost. South China University of Technology Press, Wushan, Guangzhou, Vol. 2, 1022-1027.

Kitover, D.C., van Balen, R.T., Vandenberghe, J., Roche, D.M., Renssen, H., 2016. LGM permafrost thickness and extent in the Northern Hemisphere derived from the Earth System Model iLOVECLIM. Permafrost and Periglacial Processes, 27, 31-42.

Klimchouk, A., Bayarı, S., Nazik, L., Törk, K., 2006. Glacial destruction of cave systems in high mountains, with a special reference to the Aladağlar massif, central Taurus, Turkey. Acta Carsologica, 35, 2, 111-121. 
Knight, J., Harrison, S., 2008. Periglacial and Paraglacial Processes and Environments. Geological Society of London Special Publications, 320.

Köse, O., Sarıkaya, M.A., Çiner, A., Şen, Ö.L., Candaş, A. 2017. Cosmogenic 36Cl Geochronology of the Northern Valleys of Mount Dedegöl, Western Taurus Mountains (Turkey). EGU General Assembly, Vienna, Geophysical Research Abstracts, Vol. 19, EGU2017-1377.

Košutnik, J., Gostinčar, P., Mihevc, A., 2014. Ledene jame in nekatere geomorfološke značilnosti Kočevske: vodnik po ekskurziji. (Ice caves and some geomorphological characteristics of Kočevska: field trip guide). 8 November 2014 Geomorphological Society of Slovenia, Ljubljana, pp. 37.

Krainer, K., Bressan, D., Dietre, B., Haas, J.N., Hajdas, I., Lang, K., Mair, V., Nickus, U., Reidl, D., Thies, H., Tonidandel, D., 2015. A 10,300-year-old permafrost core from the active rock glacier Lazaun, southern Ötztal Alps (South Tyrol, northern Italy). Quaternary Research, 83, 2(1), 324-335.

Kuhlemann, J., Rohling, E.J., Krumrei, I., Kubik, P., Ivy-Ochs, S., Kucera, M., 2008. Regional synthesis of Mediterranean atmospheric circulation during the last glacial maximum. Science, 321, 1338-1340.

Kuhlemann, J., Milivojević, M., Krumrei, I., Kubik, P.W., 2009. Last glaciation of the Šara Range (Balkan Peninsula): Increasing dryness from the LGM to the Holocene. Austrian Journal of Earth Science, 102, 146-158.

Kuhlemann, J., Gachev, E., Gikov, A., Nedkov, S., Krumrei, I., Kubik, P., 2013. Glaciation in the Rila Mountains (Bulgaria) during the Last Glacial Maximum. Quaternary International, 293, 51-62.

Kurter, A., 1991. Glaciers of Middle East and Africa - Glaciers of Turkey. In: Williams, R.S., Ferrigno, J.G. (Editors), Satellite Image Atlas of the World. USGS Professional Paper 1386-G-1, $1-30$.

Kwiecien, O., Arz, H.W., Lamy, F., Plessen, B., Bahr, A., Haug, G.H., 2009. North Atlantic control on precipitation pattern in the eastern Mediterranean/Black Sea region during the last glacial. Quaternary Research, 71, 375-384.

Lambeck, K., Antonioli, F., Anzidei, M., Ferranti, L., Leoni, G., Scicchitano, G., Silenzi, S., 2011. Sea level change along the Italian coast during the Holocene and projections for the future. Quaternary International, 232, 250-257.

Lantuit, H., Overduin, P.P., Couture, N., Wetterich, S., Are, F., Atkinson, D., Brown, J., Cherkashov, G., Drozdov, D., Forbes, D., Graves-Gaylord, A., Grigoriev, M., Hubberten, H.W., Jordan, J., Jorgenson, T., Ødegård, R S., Ogorodov, S., Pollard, W., Rachold, V., Sedenko, S., Solomon, S., Steenhuisen, F., Streletskaya, I., Vasiliev, A., 2012. The Arctic Coastal Dynamics database. A new classification scheme and statistics on arctic permafrost coastlines. Estuaries and Coasts, 35(2), 383-400.

Leunda. M., Bartolomé. M., Sancho. C., Moreno. A., Oliva-Urcia. B., González-Sampériz. P., Gil-Romera. G., Gomollón. A., 2015. La Cueva Helada de Casteret (PNOMP, Huesca): Primeras aportaciones del registro del hielo. In: Gómez Zotano, J., Arias García, J., Olmedo Cobo, J.A., Serrano Montes, J.L. (Editors), Avances en Biogeografía. Areas de distribución: entre puentes y barreras, Universidad de Granada, Editorial Universidad de Granada, 78-81.

Lewin, J., Macklin, M.G., Woodward, J.C., 1991. Late Quaternary fluvial sedimentation in the Voidomatis Basin, Epirus, northwest Greece. Quaternary Research, 35(1), 103-115. 
Lewis, C.J., McDonald, E.V., Sancho, C., Peña, J.L., Rhodes, E.J., 2009. Climatic implications of correlated Upper Pleistocene glacial and fluvial deposits on the Cinca and Gállego Rivers (NE Spain) based on OSL dating and soil stratigraphy. Global and Planetary Change, 67, 141-152.

Lewkowicz, A. 2010. The lasting impacts of the fourth international polar year on permafrost science. Permafrost and Periglacial Processes, 21, 105.

Liedtke, V.H., 1962. Vergletscherungsspuren und Periglazialerscheinungen am Südhang des Lovcen östlich von Kotor. Eiszeitalter und Gegenwart, 13, 15-18.

Louis, H.L., 1944. Evidence for Pleistocene glaciation in Anatolia (in German). Geologische Rundschau, 34, 7-8, 447-481.

Luetscher, M., Jeannin, P., Haeberli, W., 2005. Ice caves as an indicator of winter climate evolution: a case study from the Jura Mountains. The Holocene, 15, 982-993.

Luetscher, M., Borreguero, M., Moseley, G.E., Spotl, C., Edwards, R.L., 2013. Alpine permafrost thawing during the Medieval Warm Period identified from cryogenic cave carbonates. The Cryosphere, 7, 1073-1081.

Luetscher, M., Boch, R., Sodemann, H., Spotl, C., Cheng, H., Edwards, R.L., Frisia, S., Hof, F., Muller, W., 2015. North Atlantic storm track changes during the Last Glacial Maximum recorded by Alpine speleothems. Nature Communications, 6, 6344 .

Lugon, R., Delaloyé, R., Serrano, E., Reynard, E., Lambiel, C., González, J.J., 2004. Permafrost and Little Ice Age glacier relationships, Posets Massif, Central Pyrenees, Spain. Permafrost and Periglacial Processes, 15(3), 207-220.

Mackay, J.R., 2000. Thermally induced movements in ice-wedge polygons, western Arctic coast: a long-term study. Géographie physique et Quaternaire, 54(1), 41-68.

Magaš, D., 2002. Natural-geographic characteristics of the Boka Kotorska area as the basis of development. Geoadria, 7, 1, 51-81.

Magori, B., Onaca, A., Gachev, E., Urdea, P., 2017, The geomorphological characteristics of rock glaciers and protalus ramparts in the Rila and Pirin Mountains. Proceedings of the 9th International Conference on Geomorphology, New Delhi, abstract 302.

Makos, M., 2015. Deglaciation of the High Tatra Mountains. Cuadernos de Investigación Geográfica, 41(2), 317-335.

Marino, A., 1992. Nota preliminaire sul fenomeno glaciologico della Grotta del Gelo (Monte Etna). Geografia Fisica e Dinamica Quaternaria, 15, 127-132.

Marks, L., 2015. Last deglaciation of northern continental Europe. Cuadernos de Investigación Geográfica, 41(2), 279-293.

Martínez de Pisón, E., Arenillas, M., 1988. Los glaciares actuales del Pirineo español. La nieve en el Pirineo Español. MOPU, Madrid, 29-98.

Martínez-Cortizas, Valcárcel, M., Pérez-Alberti, A., Castillo-Rodríguez, F., Blanco-Chao, R., 1999. Cambio climático e paleoambientes cuaternarios. In: Martínez-Cortizas. A., Pérez-Alberti, A. (Editors), Atlas Climático de Galicia. Xunta de Galicia, 167-185.

Masson-Delmotte, V., Landais, A., Stievenard, M., Cattani, O., Falourd, S., Jouzel, J., Johnsen, S.J., Dahl-Jensen, D., Sveinbjörnsdottir, A.E., White, J.W.C., Popp, T., Fischer, H., 2005. Holocene climatic changes in Greenland: Different deuterium excess signals at Greenland Ice Core Project (GRIP) and NorthGRIP. Journal of Geophysical Research - Oceans, 110, D14102. 
McManus, J.F., Francois, R., Gherardi, J.M., Keigwin, L.D., Brown-Leger, S., 2004. Collapse and rapid resumption of Atlantic meridional circulation linked to deglacial climate changes. Nature, 428, 834-837.

Mensching, H., 1960. Bericht und gedanken zur tagung der kommission für periglazialforschung in der IGU in Marokko vom 19. bis 31. Oktober 1959. Zeitschrift für Geomorpholohie, 159-170.

Mercier, D., 2008. Paraglacial and paraperiglacial landsystems; concepts, temporal scales and spatial distribution. Géomorphologie. Relief, Processus, Environnement 14(4), 223-233.

Messerli, B., 1964. Der Gletscher am Erciyas Dagh und das Problem der rezenten Schneegrenze im anatolischen und mediterranen Raum. Geographica Helvetica, 19(1), 19-34.

Messerli, B., 1965. Beiträge zur Geomorphologie der Sierra Nevada (Andalusien). Juris Verlag. Zürich.

Messerli, B., 1967. Die eiszeitliche und die gegenwartige Vergletscherung in Mittelmeerraum. Geographica Helvetica, 22, 105-228.

Messerli, B., 1973. Problems of vertical and horizontal arrangement in the high mountains of the extreme arid zone (central Sahara). Artic and alpine Research, 5, 139-147.

Messerli, B., Winiger, M., 1992. Climate, environmental change and resources of the African mountains from the Mediterranean to the Equator. Mountain Research and Development, 12, 315 336.

Miccadei, E., Barberi, R., Cavinato, G.P., 1998. La geologia quaternaria della conca di Sulmona (Abruzzo, Italia centrale). Geologica Romana, 34(1), 59-86.

Mihevc, A., 2009. Cryoturbation of the sediments at the cave entrances-case studies from Skednena jama, Potočka zijalka and Bestažovca cave. Proceedings of the 51st Annual Meeting in Ljubljana, 26-27.

Mihevc, A., 2008. Distribution and characteristics of ice caves in Slovenia. In: Kadebskaya, Olga, Mavljudov, B.R., Mikhail, P. (Editors), Proceedings of the 3rd international workshop on ice caves, Kungur Ice Cave, Russia, 61-64.

Milevski, I., 2008. Fossil glacial landforms and periglacial phenomena on the Osogovo Mountain massif. Annual Report No. 37 of the Institute of Geography, Faculty of Natural Sciences and Mathematics, Skopje, 25-49.

Milivojević, M., Menković, L., Ćalić, J., 2008. Pleistocene glacial relief of the central part of Mt. Prokletije (Albanian Alps). Quaternary International, 190, 112-122.

Mithen, S., 2004. After the ice: a global human history 20,000-5,000 BC. Cambridge, MA: Harvard University Press, 664 pp.

Monegato, G., Ravazzi, C., Donegana, M., Pini, R., Calderoni, G., Wick, L., 2007. Evidence of a two-fold glacial advance during the last glacial maximum in the Tagliamento end moraine system (eastern Alps). Quaternary Research, 68, 284-302.

Monegato, G., Scardia, G., Hajdas, I., Rizzini, F., Piccin, A., 2017. The Alpine LGM in the boreal ice-sheets game. Scientific Reports, 7, doi: 10.1038/s41598-017-02148-7.

Monod, O., 1977. Recherches géologiques dans le Taurus occidental au sud de Beyşehir (Turquie). PhD Thesis, Universitity Paris Sud, Orsay. 
Moran, A.P., Ivy Ochs, S., Vockenhuber, C., Kerschner, H., 2016. Rock glacier development in the Northern Calcareous Alps at the Pleistocene-Holocene boundary. Geomorphology, 273, 178-188.

Moreno, A., Valero-Garcés, B.L., Jiménez-Sánchez, M., Domínguez-Cuesta, M.J., Mata, M.P., Navas, A., González-Sampériz, P., Stoll, H., Farias, P., Morellón, M., Corella, J.P., Rico, M., 2010. The last deglaciation in the Picos de Europa National Park (Cantabrian Mountains, Northern Spain). Journal of Quaternary Science, 25(7), 1076-1091.

Morley, M.W. and Woodward, J.C. (2011) The Campanian Ignimbrite (Y5) tephra at Crvena Stijena Rockshelter, Montenegro, Quaternary Research,75, 683-696,

Morris, S.E., Olyphant, G.A., 1990. Alpine lithofacies variation: working towards a physically based model. Geomorphology, 3, 73-90.

Mozzi, P., Ferrarese, F., Fontana, A., 2013. Document integrating Digital Elevation Models and stratigraphic data for the reconstruction of the post-LGM unconformity in the brenta alluvial megafan (north-eastern Italy). Alpine and Mediterranean Qiuaternary, 26(1), 41-54.

Nelson, F.E., Anisimov, O.A., Shiklomanov, N.I., 2001. Subsidence risk from thawing permafrost. Nature, 410, 889-90.

Nelson, F.E., Anisimov, O.A., Shiklomanov, N.I., 2002. Climate change and hazard zonation in the circum-Arctic permafrost regions. Natural Hazards, 3, 203-225.

Nieuwendam, A., Ruiz-Fernández, J., Oliva, M., Freitas, C., Paio, V., Cruces, A., 2015. Postglacial landscape changes and cryogenic processes in the Picos de Europa (Northern Spain) reconstructed from geomorphological mapping and microstructures on quartz grains. Permafrost and Periglacial Processes, 27, 96-108.

Nojarov, P., 2012a. Changes in air temperatures and atmosphere circulation in high mountainous parts of Bulgaria for the period 1941-2008. Journal of Mountain Science, 9, 185200.

Nojarov, P., 2012b. Variations in precipitation amounts, atmosphere circulation, and relative humidity in high mountainous parts of Bulgaria for the period 1947-2008. Theoretical and Applied Climatology, 107, 175-187.

Obleitner, F., Spötl, C., 2011. The mass and energy balance of ice within the Eisriesenwelt cave, Austria. The Cryosphere, 5, 245-257.

Obu, J., Košutnik, J., Overduin, P.P., Boike, J., Blatnik, M., Zwieback, S., Gostinčar, P., Mihevc, A., 2018. Sorted patterned ground in a karst cave, Ledenica pod Hrušico, Slovenia. Permafrost and Periglacial Processes, doi: 10.1002/ppp.1970.

Oliva, M., 2009. Holocene alpine environments in Sierra Nevada (Southern Spain). PhD thesis. University of Barcelona.

Oliva, M., 2011. Evolución cuaternaria del paisaje de cumbres en Sierra Nevada. Cuaternario \& Geomorfología, 25(1-2), 21-44.

Oliva, M., Gómez-Ortiz, A., 2011. Holocene slope dynamics in Sierra Nevada (Southern Spain). Sedimentological analysis of solifluction landforms and lake deposits. In: Martini, I.P., French, H.M., Pérez-Alberti, A. (Editors), Ice-Marginal and Periglacial Processes and Sediments. Geological Society, London, Special Publications, 354, 227-239.

Oliva, M., Gómez-Ortiz, A., 2012. Late Holocene environmental dynamics and climate variability in a Mediterranean high mountain environment (Sierra Nevada, Spain) inferred from lake sediments and historical sources. The Holocene, 22(8), 915-927. 
Oliva, M., Ruiz-Fernández, J., 2015. Coupling patterns between para-glacial and permafrost degradation responses in Antarctica. Earth Surface Processes and Landforms, 40(9), 1227-1238.

Oliva, M., Schulte, L., Gómez-Ortiz, A., 2011. The role of aridification in constraining the elevation range of Holocene solifluction processes and associated landforms in the periglacial belt of the Sierra Nevada (Southern Spain). Earth Surface Processes and Landforms, 36, 1279-1291.

Oliva, M., Gómez-Ortiz, A., Palacios, D., Salvador-Franch, F., Salvà-Catarineu, M., 2014. Environmental evolution in Sierra Nevada (South Spain) since the Last glaciation based on multiproxy records. Quaternary International, 353, 195-209.

Oliva, M., Gómez-Ortiz, A., Salvador-Franch, F., Salvá-Catarineu, Palacios, D., Tanarro, L., Ramos, M., Pereira, P., Ruiz-Fernández, J., 2016a. Inexistence of permafrost at the top of the Veleta peak (Sierra Nevada, Spain). Science of the Total Environment, 550, 484-494.

Oliva, M., Serrano, E., Gómez-Ortiz, A., González-Amuchástegui, M.J., Nieuwendam, A., Palacios, D., Pérez-Alberti, A., Pellitero, R., Ruiz-Fernández, J., Valcárcel, M., Vieira, G., Antoniades, D., 2016b. Spatial and temporal variability of periglaciation of the Iberian Peninsula. Quaternary Science Reviews, 137, 176-199.

Oliva, M., Pereira, P., Ruiz-Fernández, J., Nieuwendam, A., 2017. Recent advances in the study of active layer thermal regime and seasonal frost dynamics in cold climate environments. Catena, 149(2), 515-518.

Oliva, M., Ruiz-Fernández, J., Barriendos, M., Benito, G., Cuadrat, J.M., García-Ruiz, J.M., Giralt, S., Gómez-Ortiz, A., Hernández, A., López-Costas, O., López-Moreno, J.I., López-Sáez, J.A., Martínez-Cortizas, A., Moreno, A., Prohom, M., Saz, M.A., Serrano, E., Tejedor, E., Trigo, R., Valero-Garcés, B., Vicente-Serrano, S., 2018. The Little Ice Age in Iberian mountains. Earth Science Reviews, 177, 175-208.

Oliva-Urcía, B., Moreno, A., Valero-Garcés, B., Mata, P., Grupo HORDA, 2013. Magnetismo y cambios ambientales en registros terrestres: el lago de Marboré, Parque Nacional de Ordesa y Monte Perdido (Huesca). Cuadernos de Investigación Geográfica, 39(1), 117-140.

Ontañón, J., 1985. Evolución cuaternaria del valle del Paular. Publicaciones de la Universidad Complutense de Madrid, Madrid.

Ontañón, J., Asensio-Amor, I., 1973. Observaciones sobre los frentes morrenicos en el alto valle del Lozoya. Estudios Geográficos, 29, 559-562

Ortigosa, L., 1986. Geomorfología glaciar de la Sierra Cebollera (Sistema Ibérico). Instituto de Estudios Riojanos, Logroño, 77 pp.

Osmaston, H.A., Harrison, S.P., 2005. The late Quaternary glaciation of Africa: a regional synthesis. Quaternary International, 138, 32-54.

Østerud, Ø., Hønneland, G., 2014. Geopolitics and International Governance in the Arctic. Arctic Review on Law and Politics, 5(2), 156-176.

Öztürk, M., 2012. Uludağ'daki periglasiyal süreçlerin, periglasiyal yerşekillerinin ve bunları denetleyen etmenlerin incelenmesi, Nilüfer Akkılıç Kütüphanesi Yayınları, 10, 161 pp.

Palacios, D., Andrés, N., Luengo, E., 2003. Distribution and effectiveness of nivation in Mediterranean mountains: Peñalara (Spain). Geomorphology, 54(3-4), 157-178.

Palacios, D., Andrés, N., Marcos, J. Vázquez-Selem, J., 2011a. Glacial landforms and their paleoclimatic significance in Sierra de Guadarrama, Central Iberian Peninsula. Geomorphology, 139-140, 67-78. 
Palacios, D., Marcos, J. Vázquez-Selem, L., 2011b. Last Glacial Maximum and deglaciation of Sierra de Gredos, Central Iberian Peninsula. Quaternary International, 233, 16-26.

Palacios, D., Andrés, N., Marcos, J. Vázquez-Selem, J., 2012. Maximum glacial advance and deglaciation of the Pinar Valley (Sierra de Gredos, Central Spain) and its significance in the Mediterranean context. Geomorphology, 177-178, 51-61.

Palacios, D., Gómez-Ortiz, A., de Andrés, N., Vázquez-Selem, L., Salvador-Franch, F., Oliva, M., 2015. Maximum extent of Late Pleistocene glaciers and last deglaciation of La Cerdanya mountains, Southeastern Pyrenees. Geomorphology, 231, 116-129.

Palacios, D., Gómez-Ortiz, A., Andrés, N. Salvador, F., Oliva, M., 2016. Timing and new geomorphologic evidence of the Last Deglaciation stages in Sierra Nevada (southern Spain). Quaternary Science Reviews, 150, 110-129.

Palacios D., Andrés N., Gómez-Ortiz A., García-Ruiz G., 2017a. Evidence of glacial activity during the Oldest Dryas in the Mountain of Spain. In: Hughes, P., Woodward, J. (Editors), Quaternary Glaciation in the Mediterranean Mountains, Geological Society of London Special Publications, 433, 87-110.

Palacios, D., Andrés, N., García-Ruiz, J.M., Schimmelpfennig, I., Campos, N., Léanni, L., Aster Team, 2017b. Deglaciation in the central Pyrenees during the Pleistocene-Holocene transition: timing and geomorphological significance. Quaternary Science Reviews, 150, 110129.

Palade, B., Gómez-Ortiz, A., Palacios, D., 2011. Glaciares rocosos de Sierra Nevada y su significado paleoclimático: una primera aproximación. Cuadernos de Investigación Geográfica, $37,95-118$.

Palgrave, W.G., 1872. Vestiges of the glacial period in northeastern Anatolia. Nature, 5, 444445.

Pallàs, R., Rodés, A., Braucher, R., Carcaillet, J., Ortuño, M., Bordonau, J., Bourlès, D., Vilaplana, J.M., Masana, E., Santanach, P., 2006. Late Pleistocene and Holocene glaciation in the Pyrenees: a critical review and new evidence from 10Be expoisure ages, south-central Pyrenees. Quaternary Science Reviews, 25 (21-22), 2937-2963.

Palma, P., Oliva, M., García-Hernández, C., Ruiz-Fernández, J., Gómez-Ortiz, A., SalvadorFranch, F., Salvà-Catarineu, F., 2017. Spatial characterization of glacial and periglacial landforms in the high lands of Sierra Nevada (Spain). Science of the Total Environment, 584, 1256-1267.

Palmentola, G., Stamatopoulos, L., 2004. Preliminray data about sporadic permafrost on Peristeri and Tzoumerka massifs (pindos Chain, Northwestern Greece). Revue de Geomorphologie, 8, 17-23.

Palmentola, G., Baboci, K., Gruda, G.J., Zito, G., 1995. A note on rock glaciers in the Albanian Alps. Permafrost and Periglacial Processes, 6, 251-257.

Pappalardo, M., 1999. Observations on stratified slope deposits, Gesso Valley, Italian Maritime Alps. Permafrost and Periglacial Processes, 10, 107-111.

Paro, L., 2011. Il ruolo dei processi criotici nell'evoluzione del paesaggio alpino: il caso di studio dei block stream del Complesso Ultrabasico di Lanzo (Alpi occidentali italiane). PhD thesis, University of Torino.

Pauli, H., Gottfried, M., Dullinger, S., Abdaladze, O., Akhalkatsi, M., Benito-Alonso, J.L., Coldea, G., Dick, J., Erschbamer, B., Fernández-Calzado, R., Ghosn, D., Holten, J.I., Kanka, R., Kazakis, G., Kollár, J., Larsson, P., Moiseev, P., Moiseev, D., Molau, U., Molero-Mesa, J., Nagy, L., Pelino, G., Puscas, M., Rossi, G., Stanisci, A., Syverhuset, A.O., Theurillat, J.P., Tomaselli, 
M., Unterluggauer, P., Villar, L., Vittoz, P., Grabherr, G., 2012. Recent plant diversity changes on Europe's mountain summits. Science, 336, 353-355.

Pechoux, P.Y., 1970. Traces of glacial action in the Mountains of Central Greece. Revue de Géographie Alpine, 58, 211-224.

Pedraza, J., Carrasco, R.M., Domínguez-Villar, D., Villa, J., 2013. Late Pleistocene glacial evolutionary stages in the Gredos mountains (Iberian Central system). Quaternary International, $302,88-100$.

Pellicer, F., 1980. El periglaciarismo del Moncayo. Geographicalia, 7-8, 3-25.

Pellitero, R., 2009. Application of an alpine geomorphological mapping system to an Atlantic mountain environment: the Curavacas Massif (Cantabrian Range, northest Spain). Journal of Maps, 5(1), 194-205.

Pellitero, R., 2012. Geomorfología, paleoambiente cuaternario y geodiversidad en el Macizo de Fuentes Carrionas-Montaña Palentina. PhD thesis. University of Valladolid.

Pellitero, R., 2014. Geomorphology and geomorphological landscapes of Fuentes Carrionas. Journal of Maps, 10(2), 313-323.

Pellitero, R., Serrano, E., González-Trueba, J.J., 2011. Glaciares rocosos del sector central de la Montaña Cantábrica: indicadores paleoambientales. Cuadernos de Investigación Geográfica, 37(2), 119-144.

Penther, A., 1905. Eine Reise in das Gebiet des Erdschias-Dagh (Kleinasien), 1902. Abhandlungen der k. k. Geography Gesellschaft in Wien, 6, 1.

Peña, J.L., Lozano, M.V., 1998. Las formas periglaciares de la Cordillera Ibérica Centroriental. In: Peña, J.L. (Editor), Geomorfología de campo de la Sierra de Albarracín. Universidad de Verano de Teruel, 159-177.

Peña, J.L., Lozano, M.V., Sánchez-Fabre, M., Jiménez-Martínez, A., Longares, L.A., Chueca, J., Julián, A., 2000. Las acumulaciones de clima frío de la Sierra de Albarracín en el contexto de la Cordillera Ibérica Oriental. In: Peña, J.L., Sánchez- Fabre, M., Lozano, M.V. (Editors), Procesos y formas periglaciares en la montaña mediterránea. Instituto de Estudios Turolenses, Teruel, 127-147.

Pérez-Alberti, A., 1979. Nuevas observaciones sobre glaciarismo y periglaciarismo en el NW de la Península Ibérica. La Galicia sud oriental. Acta Geológica Hispana, 14, 441-444.

Pérez-Alberti, A., Rodríguez-Guitián, M., 1993. Formas y depósitos de macroclastos y manifestaciones actuales de periglaciarismo en las sierras septentrionales y orientales de Galicia. In: Pérez-Alberti, Guitián, L., Ramil, P. (Editors), La evolución del paisaje en las montañas del entorno del Camino de Santiago. Xunta de Galicia, 91-105.

Pérez-Alberti, A., Valcárcel, M., 2000. Depósitos de ladera de estructura estratificada en la Galicia oriental (Noroeste Ibérico). In: Peña, J.L., Sánchez- Fabre, M., Lozano, M.V. (Editors), Procesos y formas periglaciares en la montaña mediterránea. Instituto de Estudios Turolenses, Teruel, 22-44.

Pérez-Alberti, A., Martínez-Cortizas, A., Moares, C., 1994. Los procesos periglaciares en el Noroeste de la Península Ibérica. In: Gómez-Ortiz, A., Simón Torres, M., Salvador-Franch, F. (Eds.), Periglaciarismo en la Península Ibérica, Canarias y Baleares. Monografías de la SEG, Granada. Estudios significativos, 7, 33-54.

Pérez-Alberti, A., Valcárcel, M., Martínez-Cortizas, A., Blanco-Chao, R., 1998. Evidencias de procesos periglaciares actuales en el noroeste de la Península Ibérica deducidos a partir de 
datos climáticos, geomorfológicos y botánicos. In: Gómez-Ortiz, A., Salvador-Franch, F., Schulte, L., García-Navarro, A. (Editors), Procesos biofísicos actuales en medios fríos. Publicacions de la Universitat de Barcelona, 245-261.

Pérez-Alberti, A., Valcárcel, M., Martini, I.P. Pascucci, V., Andreucci, 2011. Upper Pleistocene glacial valley-junction sediments at Pias, Trevinca Mountains, NW Spain. In: Martini, I.P., French, H., Pérez-Alberti, A. (Editors), Ice-Marginal and Periglacial Processes and Sediments. The Geological Society. Special Publication, London, 354, 93-110.

Permenter, J.L., Oppenheimer, C., 2007. Volcanoes of the Tibesti massif (Chad, northern Africa). Bulletin of Volcanology, 69, 609-626.

Petrini M., Colleoni F., Kirchner N., Hughes L.C.A., Camerlenghi A., Rebesco M., Lucchi R.G., Forte E., Colucci R.R., Noormets R., 2018. Interplay of grounding-line dynamics and subshelf melting during the last retreat of Bjørnøyrenna Ice Stream. Scientific Reports, 8, 7196.

Planhol, X. de, Bilgin, T., 1964. Glaciaire et périglaciaire quaternaires et actuels dans le massif du Karagöl (Chaines pontiques, Turquie). Revue de Géographie Alpine, 52, 3, 497-512.

Pope, R.J., Hughes, P.D., Skourtsos, E., 2017. Glacial history of Mt Chelmos, Peloponnesus, Greece. In: Hughes, P.D., Woodward, J.C. (Editors), Quaternary glaciation in the Mediterranean Mountains. Geological Society of London Special Publications 433, 211-236.

Poser, H., 1948. Boden- und Klimaverhaltnisse in Mittel- und Westeuropa wahrend der Würmeiszeit. Erdkunde, 2, 53-68.

Poser, J., 1957. Klimamorphologische Probleme auf Kreta. Zeitschrift für Geomorphologie, $2,113-142$.

Pučnik, J., 1980. Velika knjiga o vremenu. Ljubljana, Cankarjeva založba, 367.

Radovanović, M., 1994. Pluviometrijske karakteristike NP - Lovćen. In: Mijušković, M. (Editor), Nacionalni park Lovćen - prirodna i kulturna dobra. Cetinje, 17-18 September 1993. Podgorica, Crnogorska akademija nauka i umjetnosti, 27-37.

Raynal, R., Dresch, J., Joly, F., 1956. Deux exemples regionaux de glaciation quaternaire au Maroc: Haut Atlas Oriental, Moyen Atlas Septentrional. IV Congres INQUA, Rome-Pisa, 108117.

Ravanel, L., Magnin, F., Deline, P., 2017. Impacts of the 2003 and 2015 Summer Heatwaves on Permafrost-Affected Rock-Walls in the Mont Blanc Massif. Science of the Total Environment, $609,132-143$.

Ravazzi, C., Badino, F., Marsetti, D., Patera, G., Reimer, P.J., 2012. Document Glacial to paraglacial history and forest recovery in the Oglio glacier system (Italian Alps) between 26 and 15 ka cal BP. Quaternary Science Reviews, 58, 146-161.

Reber, R., Akçar, A., Yesilyurt, S., Yavuz, V., Tikhomirov, D., Kubik, P.W., Schlüchter, C., 2014. Glacier advances in northeastern Turkey before and during the global Last Glacial Maximum. Quaternary Science Reviews, 101, 177-192.

Redondo, J.M., Carrera, P., González-Gutiérrez, R.B. Gómez-Villar, A., 2002. Caracterización de los Macizos que dominan los glaciares rocosos fósiles de la Sierra de Gistredo (León): influencia de la fracturación en la génesis y desarrollo de esas formas periglaciares. In: Serrano, E., García de Celis, A. (Editors), Periglaciarismo en montaña y altas latitudes. University of Valladolid, Valladolid, 27-36. 
Redondo, J.M., Gómez-Villar, A., González-Gutiérrez, R.B., 2004. Localización y caracterización morfométrica de los glaciares rocosos relictos de la Sierra de Gistredo (Montaña Cantábrica, León). Cuadernos de Investigación Geográfica, 30, 35-60.

Redondo, J.M., Gómez-Villar, A., González-Gutiérrez, R.B., Santos, J., 2010. Los glaciares rocosos de la Cordillera Cantábrica. University of León, León, 158 pp.

Redžić, S., Barudanović, S., Trakić, S., Kulijer, D., 2011 Vascular plant biodiversity richness and endemo-relictness of the karst mountains Prenj, Čvrsnica and Čabulja in Bosnia and Herzegovina $(\mathrm{W}$. Balkan) = Biodiverziteta in endemo-reliktnost vaskularnih rastlin kraških gorovij Prenj, Čvrsnica in Čabulja, Bosna in Hercegovina. Acta Carsologica, 40, 3, 527-555.

Rellini, I., Trombino, L., Rossi, P.M., Firpo, M., 2014. Frost activity and ice segregation in a palaeosol of the Ligurian Alps (Beigua Massif, Italy): Evidence of past permafrost? Geografia Fisica e Dinamica Quaternaria, 37(1), 29-42.

Repapis, C.C., Philandras, C.M., 1988. A note on the air temperature trends of the last 100 years as evidenced in the Eastern Mediterranean time series. Theoretical and Applied Climatology, 39, 93-97.

Ribolini, A., Fabre, D., 2006. Permafrost existence in the rock glaciers of the Argentera Massif (Maritime Alps, Italy). Permafrost and Periglacial Processes, 17, 49-63.

Ribolini, A., Guglielmin, M., Fabre, D., Bodin, X., Marchisio, M., Sartini, S., Spagnolo, M., Schoeneich, P., 2010. The internal structure of rock glaciers and recently-deglaciated slopes as revealed by geoelectrical tomography: insights on permafrost and recent glacial evolution in the Central and Western Alps (Italy-France). Quaternary Sciences Reviews, 29, 507-521.

Robinson, A., Calov, R., Ganopolski, A., 2012. Multistability and critical thresholds of the Greenland ice sheet. Nature Climate Change, 2, 429-432.

Robustelli, G., Scarciglia, F., 2006. Mormanno, 2006, e Praia a Mare (Calabria settentrionale). In: Chelli, A., D’Aquila, P., Firpo, M., Ginesu, S., Guglielmin, M., Pappalardo, M., Pecci, M., Piacentini, T., Queirolo, C., Robustelli, G., Scarciglia, F., Sias, S., Tellini, C. (Editors), Testimoni di una montagna scomparsa. Contributo alle metodologie d'indagine delle forme periglaciali relitte. Problematiche e applicazioni in differenti ambienti morfodinamici. Collana Quaderni della Montagna, vol. 8, Bologna, Bonomia University Press, 81-92.

Rodrigo, F.S., Esteban-Parra, M.J., Pozo-Vázquez, D., Castro-Díaz, Y., 1999. A 500-year precipitation record in southern Spain. International Journal of Climatology, 19, 1233-1253.

Rodríguez-Pérez, C., 1995. Estudio geomorfológico del Puerto de San Isidro. Ería, 36, 63-87.

Rodríguez-Pérez, C., 2009. Geomorfología de la montaña astur-leonesa entre los puertos de Ventana y de Somiedo. PhD thesis, University of Oviedo.

Rodríguez-Rodríguez, L., Jiménez-Sánchez, M., Domínguez-Cuesta, M.J., Aranburu, A., 2014. Research history on glacial geomorphology and geochronology of the Cantabrian Mountains, north Iberia (43-42 $\left.\mathrm{N} / 7-2^{\circ} \mathrm{W}\right)$. Quaternary International, 364, 6-21.

Rodríguez-Rodríguez, L., Jiménez-Sánchez, M., Domínguez-Cuesta, M.J., Rinterknecht, V., Pallàs, R., Bourlès, D., 2016. Chronology of glaciations in the Cantabrian Mountains (NW Iberia) during the Last Glacial Cycle based on in situ-produced 10Be. Quaternary Science Reviews, 138, $31-48$

Rossato, S., Monegato, G., Mozzi, P., Cucato, M., Gaudisoso, B., Miola, A., 2013. Late Quaternary glaciations and connections to the piedmont plain in the prealpine environment: The middle and lower Astico Valley (NE Italy). Quaternary International, 288, 8-24. 
Rosselló, V., 1977. Screes periglaciares en la montaña mallorquina. V Coloquio de Geógrafos Españoles. AGE-Universidad de Granada, Granada, 83-92.

Ruiz-Fernández, J., 2013. Las formas de modelado glaciar, periglaciar y fluviotorrencial del Macizo Occidental de los Picos de Europa (Cordillera Cantábrica). PhD thesis, University of Oviedo.

Ruiz-Fernández, J., Poblete, M.A., García, C., 2014. Características morfoclimáticas y procesos y formas periglaciares actuales en el Macizo Occidental de los Picos de Europa (Cordillera Cantábrica). In: Gómez-Ortiz, A., Salvador, F., Oliva, M., Salvà, M. (Editors), Avances, métodos y técnicas en el estudio del periglaciarismo. University of Barcelona, Barcelona, 91-103.

Ruiz-Fernández, J., Oliva, M., Cruces, A., Lopes, V., Freitas, C., Andrade, C., GarcíaHernández, C., López-Sáez, J.A., Geraldes, M., 2016. Environmental evolution in the Picos de Europa (Cantabrian Mountains, SW Europe) since the Last Glaciation. Quaternary Science Reviews, 138, 87-104.

Ruszkiczay-Rüdiger, Z., Kern, Z., 2015. Permafrost or seasonal frost? A review of paleoclimate proxies of the last glacial cycle in the East Central European lowlands. Quaternary International, 415, 241-252.

Salvador-Franch, F., Gómez-Ortiz, A., Palacios, D., 2010. Comportamiento térmico del suelo en un enclave de alta montaña mediterránea con permafrost residual: Corral del Veleta (Sierra Nevada, Granada. España). In: Blanco, J.J., de Pablo, M.A., Ramos, M. (Editors), Ambientes periglaciares, permafrost y variabilidad climática. Publicaciones de la Universidad de Alcalá, Alcalá de Henares (Spain), 61-68.

Salvador-Franch, F., Gómez-Ortiz, A., Salvà-Catarineu, M., Palacios, D., 2011. Caracterización térmica de la capa activa de un glaciar rocoso en medio periglaciar de alta montaña mediterránea: El ejemplo del Corral del Veleta (Sierra Nevada, España). Cuadernos de Investigación Geográfica, 37(2), 25-48.

Samartin, S., Heiri, O., Kaltenrieder, P., Kühl, N., Tinner, W., 2016. Reconstruction of full glacial environments and summer temperatures from Lago della Costa, a refugial site in Northern Italy. Quaternary Science Reviews, 143, 107-119.

Samartin, S., Heiri, O., Joos, F., Renssen, H., Franke, J., Brönnimann, S., Tinner, W., 2017. Warm Mediterranean mid-Holocene summers inferred from fossil midge assemblages. Nature Geoscience, 10, 207-212.

Sancho, C., Bartolomé, M., Moreno, A., Belmonte, A., Leunda, M., Oliva-Urcia, B., LópezMartínez, J., Delgado-Huertas, A., 2016. Las cuevas heladas del Pirineo como sensores paleoambientales: estado de la cuestión. Geo-Temas, 16(1), 311-314.

Santos-González, J., 2010. Glaciarismo y periglaciarismo en el Alto Sil, provincia de León (Cordillera Cantábrica). $\mathrm{PhD}$ thesis. University of León.

Sanz, E., Pellicer, F., 1994. El periglaciarismo de la Sierra Cebollera (Soria y La Rioja). Cuaternario \& Geomorfología, 8(1-2), 123-138.

Sanz-Herráiz, C., 1988. El relieve del Guadarrama Oriental. Consejería de Política Territorial, Madrid.

Sarıkaya, M.A., 2012. Recession of the ice cap on Mount Ağr1 (Ararat), Turkey, from 1976 to 2011 and its climatic significance. Journal of Asian Earth Sciences, 46, 190-194. 
Sarıkaya, M.A., Tekeli, A.E., 2014. Satellite inventory of glaciers in Turkey. In: Kargel, J.S., Leonard, G.J., Bishop, M.P., Kääb, A., Raup, B. (Editors), Global Land Ice Measurements from Space, Praxis-Springer (Publisher), Berlin Heidelberg, 465-480.

Sarıkaya, M.A., Çiner, A., 2015. Late Pleistocene glaciations and paleoclimate of Turkey. Bulletin of Mineral Research and Exploration (MTA), 151, 107-127.

Sarıkaya, M.A., Çiner, A., 2017. The late Quaternary glaciation in the Eastern Mediterranean. In: Hughes, P.D., Woodward, J.C. (Editors), Quaternary Glaciation in the Mediterranean Mountains, Geological Society of London Special Publication, 433, 289-305.

Sarıkaya, M.A., Çiner, A., Zreda, M., 2003. Erciyes volkanı Geç Kuvaterner buzul çökelleri. HU Yerbilimleri, 27, 59-74.

Sarıkaya, M. A., Zreda, M., Çiner, A., 2009. Glaciations and paleoclimate of Mount Erciyes, central Turkey, since the Last Glacial Maximum, inferred from $36 \mathrm{Cl}$ cosmogenic dating and glacier modelling. Quaternary Science Reviews, 28(23-24), 2326-2341.

Sarıkaya, M.A., Çiner, A., Zreda, M., 2011. Quaternary glaciations of Turkey. In: Ehlers, J., Gibbard, P.L., Hughes, P.D. (Editors), Quaternary Glaciations - extent and chronology; a closer look, Elsevier Publications, Developments in Quaternary Science, Amsterdam, 15, 393-403.

Sarıkaya, M.A., Çiner, A., Yıldırım, C. 2017. Cosmogenic ${ }^{36} \mathrm{Cl}$ glacial chronologies of the Late Quaternary glaciers on Mount Geyikdağ in the Eastern Mediterranean. Quaternary Geochronology, 39, 189-204.

Sarıkaya, M.A., Zreda, M., Çiner, A., Zweck, C., 2008. Cold and wet Last Glacial Maximum on Mount Sandiras, SW Turkey, inferred from cosmogenic dating and glacier modelling. Quaternary Science Reviews, 27(7-8), 769-789.

Sarıkaya, M.A., Çiner, A., Haybat, H., Zreda, M., 2014. An early advance of glaciers on Mount Akdağ, SW Turkey, before the global Last Glacial Maximum; insights from cosmogenic nuclides and glacier modeling. Quaternary Science Reviews, 88, 96-109.

Scapozza, C., Lambiel, C. Reynard, E., Fallot, JM., Antognini, M., Schoeneich, P., 2010. Radiocarbon Dating of Fossil Wood Remains Buried by the Piancabella Rock Glacier, Blenio Valley (Ticino, Southern Swiss Alps): Implications for rock glacier, treeline and climate history, Permafrost and Periglacial Processes, 21, 90-96.

Scarciglia, F., 2000. Variazioni tardo-quaternarie delle morfodinamiche di versante in Appennino meridionale: il contributo della paleopedologia. PhD thesis, University of Napoli.

Scarciglia, F., Terribile, F., Colombo, C., Cinque, A., 2003. Late Quaternary climatic changes in Northern Cilento (Southern Italy): an integrated geomorphological and paleopedological study. Quaternary International, 106-107, 141-158.

Schuur, E.A.G., McGuire, A.D., Schädel, C. Grosse, G., Harden, J.W., Hayes, D.J., Hugelius, G., Koven, C.D., Kuhry, P., Lawrence, D.M., Natali, S.M., Olefeldt, D., Romanovsky, V.E., Schaefer, K., Turetsky, M.R., Treat, C.C., Vonk, J.E., 2015. Climate change and the permafrost carbon feedback. Nature, 520(7546), 171-179.

Scoto, F., Giudice, G., Randazzo, L., Maggi, V., 2016. Air circulation model and topographic survey of the "grotto del gelo", Mt. Etna Italy. In: Mihevc, A., Zupan Hajna, N., Gostinčar, P. (Editors), Proceedings of the 7th International Workshop on Ice Caves, pp. 71-73.

Scotti, R., Brardinoni, F., Alberti, S., Frattini, P., Crosta, G.B., 2013. A regional inventory of rock glaciers and protalus ramparts in the central Italian Alps. Geomorphology, 186, 136-149. 
Şengör, A.M.C., Yilmaz, Y., 1981. Tethyan evolution of Turkey: a plate tectonic approach. Tectonophysics, 75, 181-241.

Seppi, R., Carton, A., Zumiani, M., Dall'Amico, M., Zampedri, G., Rigon, R., 2012. Inventory, distribution and topographic features of rock glaciers in the southern region of the eastern Italian Alps (Trentino). Geografia Fisica e Dinamica Quaternaria, 35, 185-197.

Seppi, R., Zanoner, T., Carton, A., Bondesan, A., Francese, R., Carturan, L., Zumiani, M., Giorgi, M., Ninfo, A., 2014. Current transition from glacial to periglacial processes in the Dolomites (South-Eastern Alps). Geomorphology, 228, 71-86.

Serrano, E., 1998. Geomorfología del Alto Gállego (Pirineo aragonés). Fundación Fernando El Católico, Zaragoza.

Serrano, E., Agudo, C., 1998. Los glaciares rocosos de los Pirineos. Implicaciones ambientales. In: Gómez-Ortiz, A., Salvador-Franch, F., Schulte, L., García-Navarro, A. (Editors), Procesos biofísicos actuales en medios fríos. Publicacions de la Universitat de Barcelona, 133154.

Serrano, E., Agudo, C., 2004. Glaciares rocosos y deglaciación en la alta montaña de los Pirineos aragoneses (España). Boletín de la Real Sociedad Española de Historia Natural, 99, 159172.

Serrano, E., Agudo, C., Martínez De Pisón, E., 1999. Rock glaciers in the Pyrenees. Permafrost and Periglaclacial Processes, 10, 101-106.

Serrano, E., Martínez de Pisón, E., Agudo, C., 2000. El medio periglaciar de alta montaña en el Pirineo central: aportaciones recientes. In: Peña, J.L., Sánchez- Fabre, M., Lozano, M.V. (Editors), Procesos y formas periglaciares en la montaña mediterránea. Instituto de Estudios Turolenses, Teruel, 45-62.

Serrano, E., Agudo, C., Delaloyé, R., González-Trueba, J.J., 2001. Permafrost distribution in the Posets massif, Central Pyrenees. Norwegian Journal of Geography, 55(4), 245-252.

Serrano, E., Agudo, C., González Trueba, J.J., 2002. La deglaciación de la alta montaña del macizo del Posets (Pirineo aragonés). Morfología, evolución y fases morfogenéticas glaciares. Cuaternario y Geomorfología, 16, 111-126.

Serrano, E., San José, J.J., Agudo, C., 2006. Rock glacier dynamics in a marginal periglacial high mountain environment: flow, movement (1991-2000) and structure of the Argualas rock glacier, the Pyrenees. Geomorphology, 74, 285-296.

Serrano, E., Pellitero, R., Otero, M., 2010a. Huellas pleistocenas de frío intenso en la Cuenca del Duero: cuñas de arena relictas en las terrazas del Pisuerga. In: Úbeda, X., Vericat, D., Batalla, R.J. (Editors), Avances de la Geomorfología en España, 2008-2010. SEG-Universitat de Barcelona, Barcelona, 417-420.

Serrano, E., Agudo, C., Delaloyé, R., González, J.J., 2010b. Permafrost distribution in the Posets massif, Central Pyrenees. Norsk Geografisk Tidsskrift, 55(4), 245-252.

Serrano, E., Sanjosé, J.J., González Trueba, J.J., 2010c. Rock glaciers dynamics in marginal periglacial environments. Earth Surface Processes and Landforms, 35(11), 1302-1314.

Serrano, E., González-Trueba, J.J., San José, J.J., 2011a. Dinámica, evolución y estructura de los glaciares rocosos de los Pirineos. Cuadernos de Investigación Geográfica, 37, 145-169.

Serrano, E., Morales, C., González Trueba, J.J., Martín, R., 2009. Cartografía del permafrost de montaña en los Pirineos españoles. Finisterra, 87, 45-54. 
Serrano, E., González-Trueba, J.J., San José, J.J., Del Río, L.M., 2011b. Ice patch origin, evolution and dynamics in a temperate maritime high mountain: the Jou Negro, Picos De Europa (NW Spain). Geographiska Annaler, 9(2), 57-70.

Serrano, E., González-Trueba, J.J., González-García, M., 2012. Mountain glaciation and paleoclimate reconstruction in the Picos de Europa (Iberian Peninsula, SW Europe). Quaternary Research, 78, 303-314.

Serrano, E., González-Trueba, J.J., Pellitero, R., González-García, M., Gómez, M., 2013. Quaternary glacial evolution in the Cantabrian Mountains (Northern Spain). Geomorphology, $196,65-82$.

Serrano, E., Gómez-Lende, M., González-Amuchastegui, M.J., González-García, M., González-Trueba, J.J., Pellitero, R., Rico, I., 2015. Glacial chronology, environmental changes and implications for human occupation during the upper Pleistocene in the eastern Cantabrian Mountains. Quaternary International, 364, 22-34.

Simón, M., Sánchez, S., García, I., 2000. Soil-landscape evolution on a Mediterranean high mountain. Catena, 39, 211-231.

Sinnyovsky, D., 2015. Wurm glacier formations and mountain landscapes in Rila Mountain, Bulgaria. Proceedings of the 15th International Multidisciplinary Scientific GeoConference SGEM 2015, 1, 529-536.

Smiraglia, C., Fabre, D., Evin, M., Assier, A., 1994. The rock glaciers of the Manzina, Valfurva, Stelvio National Park, Italy. Geoelectrical soundin, Geografia Fisica e Dinamica Quaternaria, 17(1), 79-85.

Smith, G.W., Nance, R.D., Genes, A.N., 1997. Quaternary glacial history of Mount Olympus. Geological Society of America Bulletin, 109, 809-824.

Smith, J.A., Andersen, T.J., Shortt, M., Gaffney, A.M., Truffer, M., Stanton, T.P., Bindschadler, R., Dutrieux, P., Jenkins, A., Hillenbrand, C.D., Ehrmann, W., Corr, H.F.J., Farley, N., Crowhurst S., Vaughan, D.G., 2017. Sub-ice-shelf sediments record history of twentiethcentury retreat of Pine Island Glacier. Nature, 541, 77-80.

Soutadé, G., 1980. Modelé et dynamique actualle des versants supraforestiers des Pyrénées Orientales. Imp. Coop. du Sud-Ouest, Albi, 452 pp.

Staut, M., Vreča, P., Merela, M., Brenčič, M., 2016. Recent fluctuations of ice deposits in the cave Ledena jama pri Planini Viševnik, NW Slovenia. In: Mihevc, A., Zupan Hajna, N., Gostinčar, P. (Editors), Proceedings of the 7th International Workshop on Ice Caves, 73-74.

Stefanova, I., Atanassova, J., Delcheva, M., Wright, H. E., 2006. Chronological framework for the Lateglacial pollen and macrofossil sequence in the Pirin Mountains, Bulgaria: Lake Besbog and Lake Kremensko-5. The Holocene, 16, 6, 877-892.

Stenni, B., Genoni, L., Flora, O., Guglielmin, M., 2007. An oxygen isotope record from the Foscagno rock-glacier ice core, upper Valtellina, Italian central Alps. The Holocene, 17, 10331039.

Stoffel, M., Luetscher, M., Bollschweiler, M., Schlatter, F., 2009. Evidence of NAO control on subsurface ice accumulation in a $1200 \mathrm{yr}$ old cave-ice sequence, St Livres ice cave, Switzerland. Quaternary Research, 72, 16-26.

Stoyanov, K., Gachev, E., 2012. Recent Landform Evolution in Bulgaria. In: Lóczy, D., Stankoviansky, M., Kotarba, A. (Editors), Recent Landform Evolution: The Carpatho-BalkanDinaric Region, Springer, Dordrecht, New York, 377-412. 
Stroeven, A.P., Hättestrand, C., Kleman, J., Heyman, J., Fabel, D., Fredin, O., Goodfellow, B.W., Harbor, J.M., Jansen, J.D., Olsen, L., Caffee, M.W., Fink, D., Lundqvist, J., Rosqvist, G.C., Strömberg, B., Jansson, K.N., 2016. Deglaciation of Fennoscandia. Quaternary Science Reviews, $147,91-121$

Styllas, M., Schimmelpfennig, I., Ghilardi, M., Benedetti, L., 2016. Geomorphologic and palaeoclimatic evidence of Holocene glaciation on Mount Olympus, Greece. The Holocene, 26, 709-721.

Tanarro, L.M., Palacios, D., Zamorano, J.J., Gómez-Ortiz, A., 2010. Cubierta nival, permafrost y formación de flujos superficiales en un talud detrítico de alta montaña (Corral del Veleta, Sierra Nevada, España). Cuadernos de Investigación Geográfica, 36(2), 39-60.

Temovski, M., 2016. Ice caves in Macedonia. In: Mihevc, A., Zupan Hajna, N., Gostinčar, P. (Editors), Proceedings of the 7th International Workshop on Ice Caves, 74.

Tihay, J.P., 1973. Note sur quelques paléoformes periglaciaires observées en Algérie orientale. Méditerranée, 13(2), 37-47.

Thornes, J.B., 1968. Glacial and periglacial features in the Urbión Mountains. Spain. Estudios Geológicos, 24, 249-258.

Tonkov, S., Bozilova, E., Possnert, G., 2016. Lateglacial to Holocene vegetation development in the Central Rila Mountains, Bulgaria. The Holocene, 26, 17-28.

Toucanne, S., Soulet, G., Freslon, N., Silva, R., Dennielou, B., Zaragosi, S., Eynaud, F., Bourillet, J.F., Bayon, G., 2015. Millennial-scale fluctuations of the European Ice Sheet at the end of the last glacial, and their potential impact on global climate. Quaternary Science Reviews, $123,113-133$.

Türkeş, M., Öztürk, M.Z., 2008. Uludağ periglasiyal jeomorfolojisi. Ulusal jeomorfoloji Sempozyumu, 387-395.

Türkeş, M., Öztürk, M.Z., 2011. Uludağ'da girland ve çember oluşumları, Coğrafi Bilimler Dergisi, 2, 239-257.

Turoğlu, H., 2009. Aksu Deresi Havzası (Giresun) Periglasiyal Sahasında Kütle Hareketleri. Türk Coğrafya Dergisi, 52, 41-54.

Tzedakis, P.C., Frogley, M.R., Lawson, I.T., Preece, R.C., Cacho, I., de Abreu, L., 2004. Ecological thresholds and patterns of millennial-scale climate variability: The response of vegetation in Greece during the last glacial period. Geology, 32, 109-112.

Ugarte, F. M., 1992. Glacial and periglacial morphogenesis in the Basque mountains. The Late Quaternary in the Western Pyrenean Region, University of of the Basque Country, 235-250.

Ünal, A., Sarıkaya, M.A., 2013. Erciyes kaya buzulunun uzaktan algilama ile incelenmesi (2001-2012). Coğrafyacılar Derneği Yıllık Kongresi Bildiriler Kitabı, İstanbul, 1-5.

Valcárcel, M., 1998. Evolución geomorfológica y dinámica de vertientes en el NE de Galicia. Importancia de los procesos de origen frío en un sector de las montañas lucenses. $\mathrm{PhD}$ thesis, University of Santiago de Compostela.

Valcárcel, M., Pérez-Alberti, A., 2002. Los campos de bloques en montañas del noroeste de la Península Ibérica: Génesis y significado paleoambiental. In: Serrano, E., García de Celis, A. (Editors), Periglaciarismo en montaña y altas latitudes. University of Valladolid, Valladolid, 1326.

Valcárcel, M., Blanco, R., Martínez-Cortizas, A., Pérez-Alberti, A., 1998. Estimación de las paleotemperaturas en Galicia durante el último ciclo glaciar a partir de datos geomorfologicos y 
climáticos. In: Gómez-Ortiz, A., Salvador-Franch, F., (Editors), Investigaciones recientes de la geomorfología española, Sociedad Española de Geomorfología, 767-770.

van Vliet-Lanoë, B.M.J., Hallegouët, B., 2001. European permafrost at the LGM and at its maximal extent. In: Paepe, R., Melnikov, V.P., Van Overloop, E., Gorokhov, V.D. (Editors), Permafrost response on economic development, environmental security and natural resources. Springer Netherlands, Dordrecht, 195-213.

van Vliet-Lanoe, B., Magyarib, A., Meilliez, F., 2004. Distinguishing between tectonic and periglacial deformations of quaternary continental deposits in Europe. Global and Planetary Change, 43, 103-127.

Vandenberghe, J., French, H.M., Gorbunov, A., Velichko, A.A., Jin, H., Cui, Z., Zhang, T., Wan, X., 2014. The Last Permafrost Maximum (LPM) map of the northern hemisphere: permafrost extent and mean annual air temperatures, 25-17 ka BP. Boreas, 43, 652-666.

Velichko, A.A., 1982. Paleogeography of Europe during the last one hundred thousand years. In: Gerasimov, I.P. (Editor), 14 Planches. Moscow, 156.

Vieira, G., 2004. Geomorphology of the high valleys and plateaus of Serra da Estrela. Pleistocene cold environments and present-day processes. $\mathrm{PhD}$ thesis, University of Lisbon.

Vieira, G., Mora, C., Ali, F., 2017. New observations indicate the possible presence of permafrost in North Africa (Djebel Toubkal, High Atlas, Morocco). The Cryosphere, 11(4), 16911705.

Vieira, G., Bockheim, J., Guglielmin, M., Balks, M., Abramov, A.A., Boelhouwers, J., Cannone, N., Ganzert, L., Gilichinsky, D., Goryachkin, S., López-Martínez, J., Raffi, R., Ramos, M., Schaefer, C., Serrano, E., Simas, F., Sletten, R., Wagner, D., 2010. Thermal state of permafrost and active-layer monitoring in the Antarctic: advances during the international polar year 2007-2008. Permafrost and Periglacial Processes, 21, 182-197.

Wiche, K., 1953. Klimamorphologische und talgeschichtliche studien im M'Goungebiet, Mitteilungen der geologischen Gesellschaft in Wien, 95, 4-41.

Williams, C., Flower, B.P. Hastings, D.W., 2012. Seasonal Laurentide Ice Sheet melting during the Mystery Interval (15.5-14.5 ka). Geology, 40, 955-958.

Witak, M., Wachnicka, A., Kuijpers, A., Troelstra, S., Prins, A., Witkowski, A., 2015. Holocene North Atlantic surface circulation and climatic variability: evidence from diatom records. The Holocene, 15(1), 85-96.

Woodward, J.C., 2009. (Editor) The Physical Geography of the Mediterranean. Oxford, Oxforrd University Press.

Woodward, J.C., Goldberg, P., 2001. The sedimentary records in Mediterranean rockshelters and caves: Archives of environmental change. Geoarchaeology: An International Journal, 16, $327-354$

Woodward, J.C., Lewin, J., Macklin, M.G., 1995. Glaciation, river behaviour and the Palaeolithic settlement of upland northwest Greece. In Lewin, J., Macklin, M.G., Woodward (Editors), Mediterranean Quaternary River Environments. Balkema, 115-129.

Woodward, J.C., Hamlin, R.H.B., Macklin, M.G., Hughes, P.D., Lewin, J., 2008. Glacial activity and catchment dynamics in northwest Greece: Long-term river behaviour and the slackwater sediment record for the last glacial to interglacial transition. Geomorphology, 101, 4467. 
World Meteorological Organisation, 1998. 1961-1990 global climate normals. Electronic resource. National Climatic Data Center, US: Asheville, NC.

Xoplaki, E., Maheras, P., Luterbacher, J., 2008. Variability of climate in meridional Balkans during the periods 1675-1715 and 1780-1830 and its impact on human life. Climatic Change, 48, 581-615.

Yavaşl1, D.D., Tucker, C.J., Melocik, K.A., 2015. Change in the glacier extent in Turkey during the Landsat Era. Remote Sensing of Environment, 163, 32-41.

Yeşilyurt, S., Doğan, U., 2010. Munzur Dağları'nın buzul jeomorfolojisi: CBS ve uzaktan algılama yöntemleri ile bir değerlendirme, TÜCAUM VI. Ulusal Coğrafya Sempozyumu, Ankara, 287-288.

Yeşilyurt, S., Akçar, N., Doğan, U., Yavuz, V., Ivy-Ochs, S., Vockenhuber, C., Schlunegger, F., Schlüchter, C., 2016. Extensive Quaternary glaciations in eastern Turkey. EGU General Assembly 2016, Vol. 18, EGU2016-1014.

Yeşilyurt, S., Doğan, U., Akçar, N., 2018. Narlıca Vadisi'nde Geç Kuvaterner buzullaşma izleri, Kavuşşahap Dağları. Türk Coğrafya Dergisi, (70), 99-108.

Zahno, C., Akçar, N., Yavuz, V., Kubik, P.W., Schlüchter, C., 2009. Surface exposure dating of Late Pleistocene glaciations at the Dedegöl Mountains (Lake Beyşehir, SW Turkey). Journal of Quaternary Science, 24, 1016-1028.

Zahno, C., Akçar, N., Yavuz, V., Kubik, P.W., Schlüchter, C., 2010. Chronology of Late Pleistocene glacier variations at the Uludağ Mountain, NW Turkey. Quaternary Science Reviews, 29, 1173-1187.

Zenklusen-Mutter, E., Blanchet, J., Phillips, M., 2010. Analysis of ground temperature trends in alpine permafrost using generalized least squares. Journal of Geophysical Research: Earth Surface, 115, F04009.

Zreda, M., Çiner, A., Sarıkaya, M.A., Zweck, C., Bayarı, S., 2011. Remarkably extensive Early Holocene glaciation in Aladağlar, Central Turkey, Geology, 39, 11, 1051-1054.

Zubrzycki, S., Kutzbach, L., Pfeiffer, E.M., 2014. Permafrost-affected soils and their carbon pools with a focus on the Russian Arctic. Solid Earth, 5, 595-609.

Zumbühl, H.J., Steiner, D., Nussbaumer, S., 2008. 19th century glacier representations and fluctuations in the central and western European Alps: an interdisciplinary approach. Global and Planetary Change, 60(1-2), 42-57.

Zupan Hajna, N., 2007. Barka depression, a denuded shaft in the area of Snežnik Mountain. Southwest Slovenia. Journal of Cave and Karst Studies, 69/2. 266-274.

Zupan Hajna, N., 2016. Interesting karst depression in the area of Snežnik Mountain; SW Slovenia. In: Mihevc, A., Zupan Hajna, N., Gostinčar, P. (Editors), Proceedings of the 7th International Workshop on Ice Caves, 76.

Žebre, M., Stepišnik, U., 2014. Reconstruction of Late Pleistocene glaciers on Mount Lovćen, Montenegro. Quaternary International, 353, 225-235.

Žebre, M., Stepišnik, U., Colucci, R.R., Forte, E., Monegato, G., 2016. Evolution of a karst polje influenced by glaciation: the Gomance piedmont polje (northern Dinaric Alps). Geomorphology, 257, 143-154. 


\section{$\underline{\text { Figure captions }}$}

Figure 1. Location of the different study areas examined in this paper within the Mediterranean region (top), together with mean annual temperatures and altitudes where the $0{ }^{\circ} \mathrm{C}$ isotherm is located (middle), and annual precipitations with values for each of the mountain ranges considered in this study (bottom). Annual precipitation and mean annual temperatures for the period 1960-1990 was obtained from Hijmans et al. (2005), spatial resolution 30 arc-seconds, modified after WorldClim 1.4 (www.worldclim.org).

Figure 2. Distribution of permafrost-related features since the Last Glaciation in the Iberian Peninsula. The symbols of the legend are the same for all the other graphs.

Figure 3. Examples of permafrost-related landforms generated during different phases in different massifs of the Iberian Peninsula.

Figure 4. Distribution of permafrost-related features since the Last Glaciation in the southern Alps.

Figure 5. Minimum mean altitude of the relict rock glacier fronts in the southern side of the Alps, including data from (1) Bornet et al. (2014); 2) Seppi et al. (2012); (3) Colucci et al. (2016a).

Figure 6. Examples of periglacial and permafrost-related landforms generated during different phases in the southern Alps.

Figure 7. Distribution of permafrost-related features since the Last Glaciation in the Italian Peninsula.

Figure 8. Examples of permafrost-related landforms generated during different phases in the Apennines and Italian Peninsula.

Figure 9. Distribution of permafrost-related features since the Last Glaciation in the Balkan Peninsula.

Figure 10. Examples of permafrost-related landforms generated during different phases in different massifs of the Balkan Peninsula.

Figure 11. Distribution of permafrost-related features since the Last Glaciation in the Anatolia Peninsula.

Figure 12. Examples of permafrost-related landforms generated during different phases in different massifs of the Anatolia Peninsula.

Figure 13. Distribution of permafrost-related features since the Last Glaciation in northern Africa.

Figure 14. Examples of permafrost-related landforms generated during different phases in northern Africa.

Figure 15. Geomorphological sketch of the formation of different generations of permafrostrelated features in Mediterranean mountains since the Last Glaciation. 


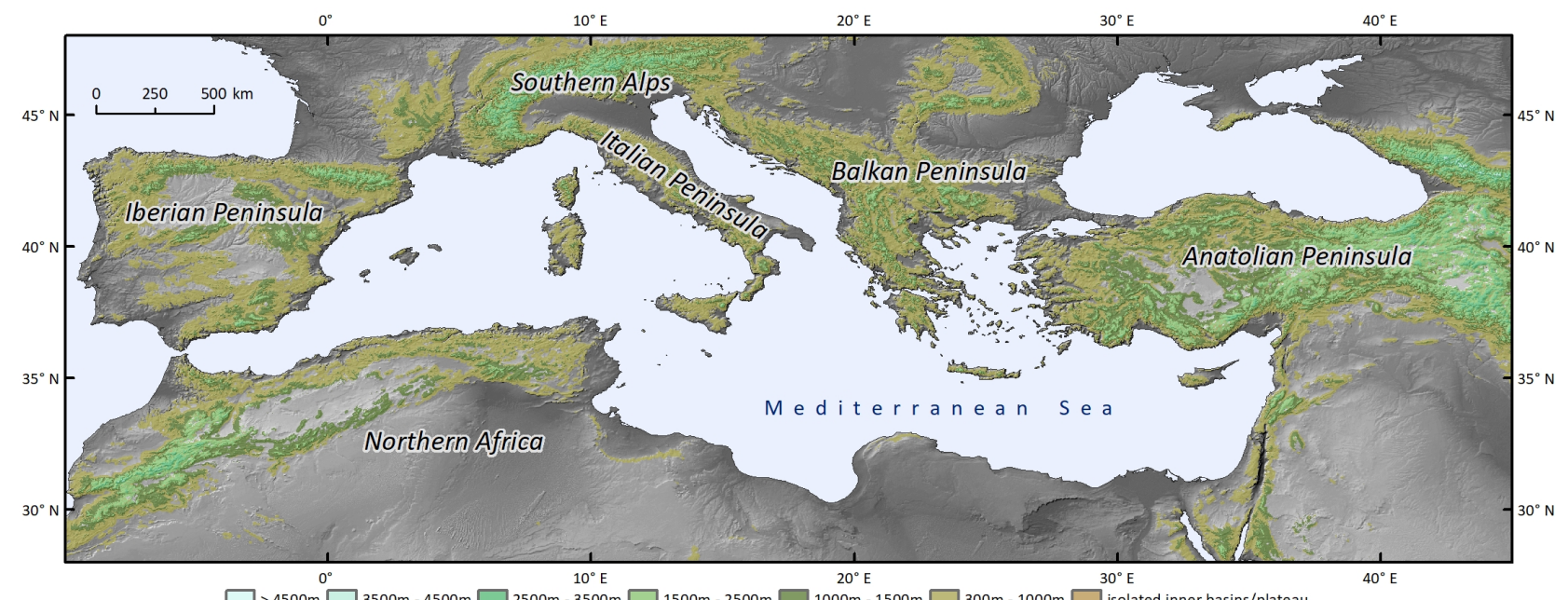

$\square>4500 \mathrm{~m} \square$ 3500m - 4500m $\square 2500 \mathrm{~m}$-3500m $\square$ 1500m - 2500m $\square$ 1000m - 1500m $\square$ 300m - 1000m $\square$ isolated inner basins/plateau
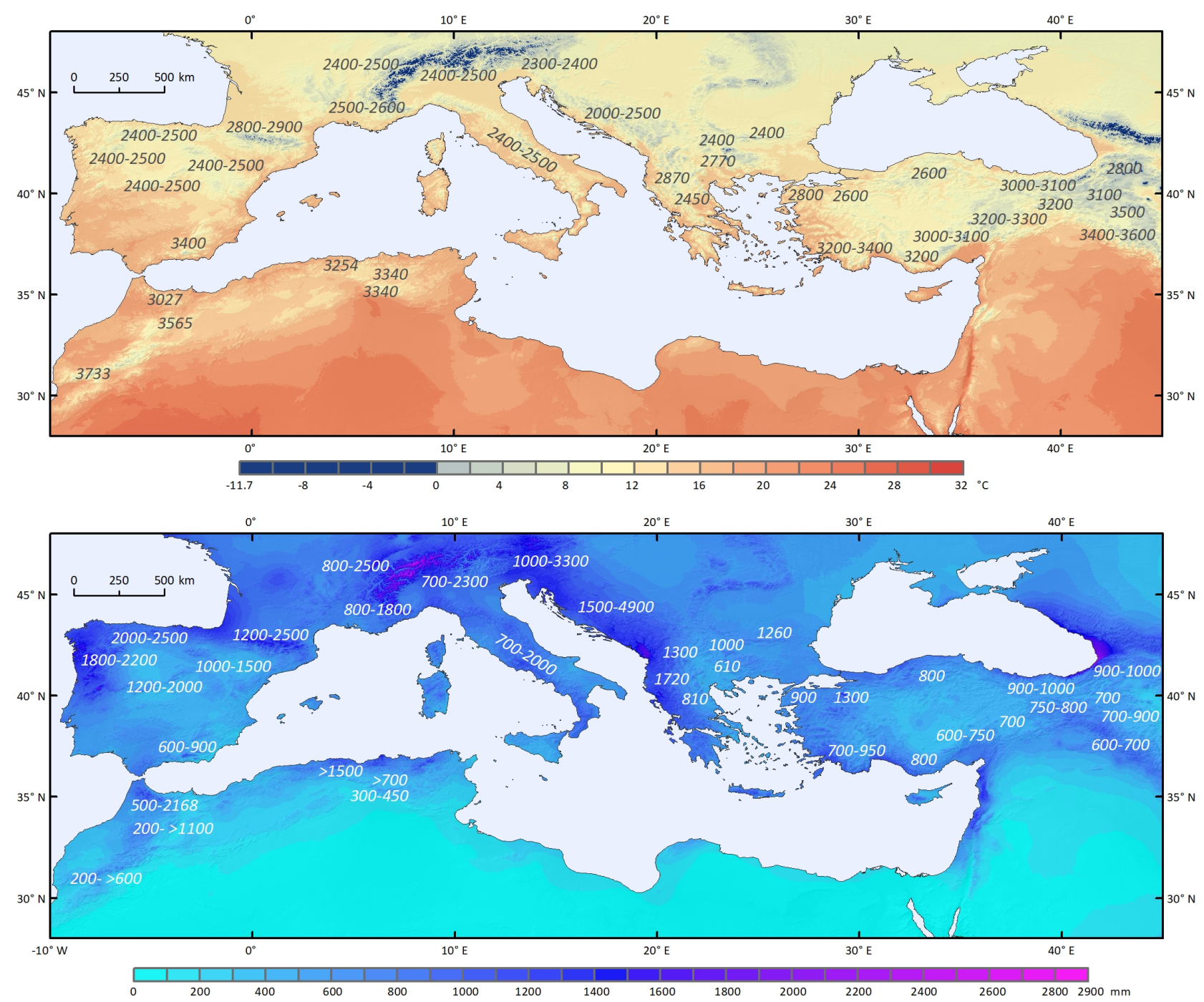


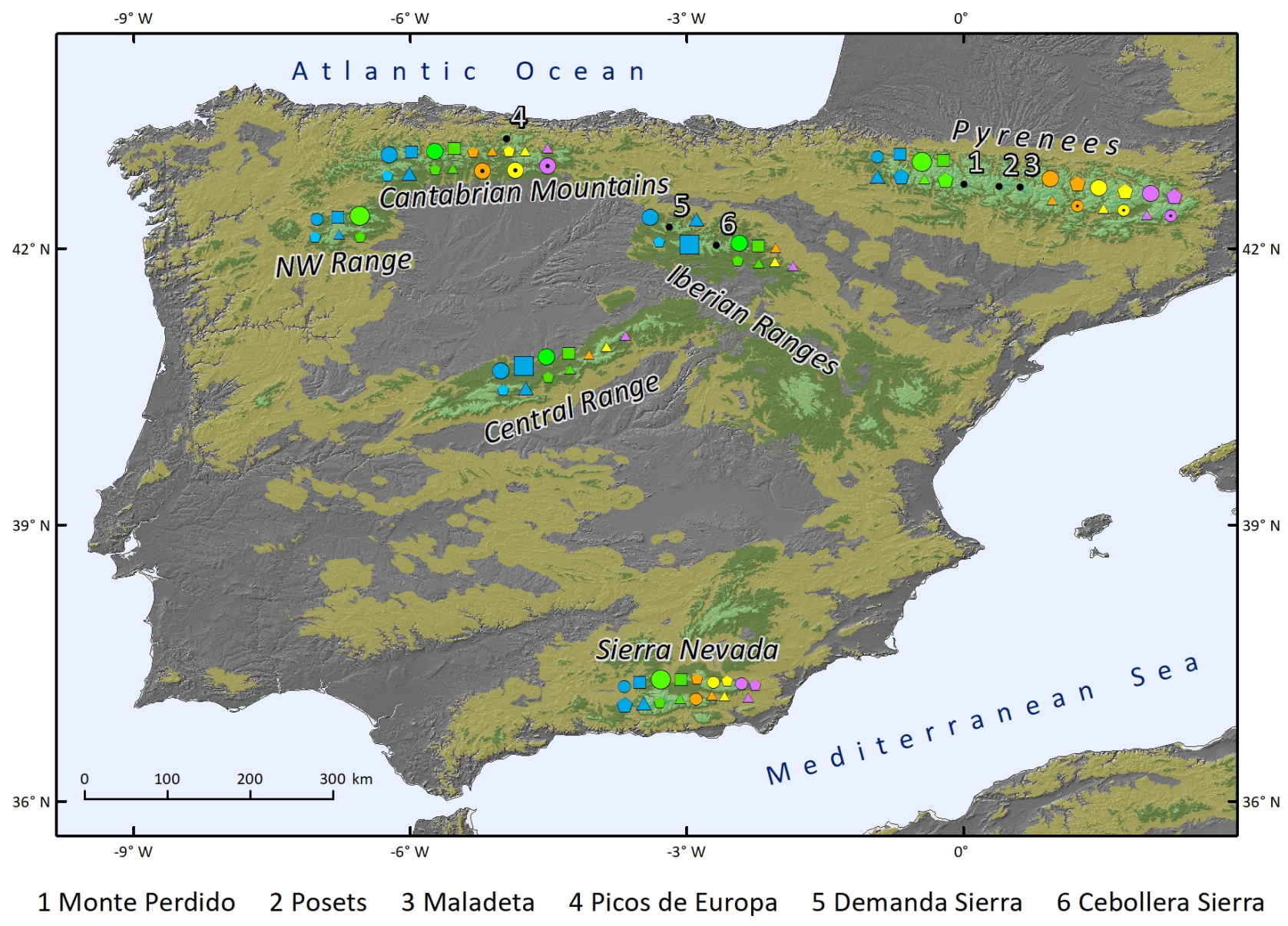
Landform
Phase
Rock glacier
Last Glaciation
$\square$ Block stream
Deglaciation
Protalus lobe
Holocene
$\triangle$ Patterned ground
- Ice cave
LIA
$\diamond$ Ice wedge
Present-day

\section{Frequency}

Very abundant

- Moderately abundant 


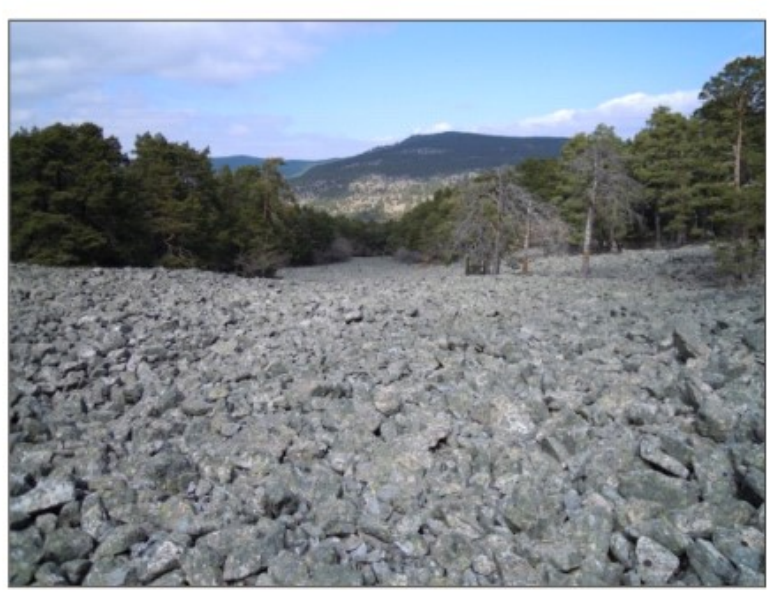

Last Glaciation (block streams; Iberian Range)

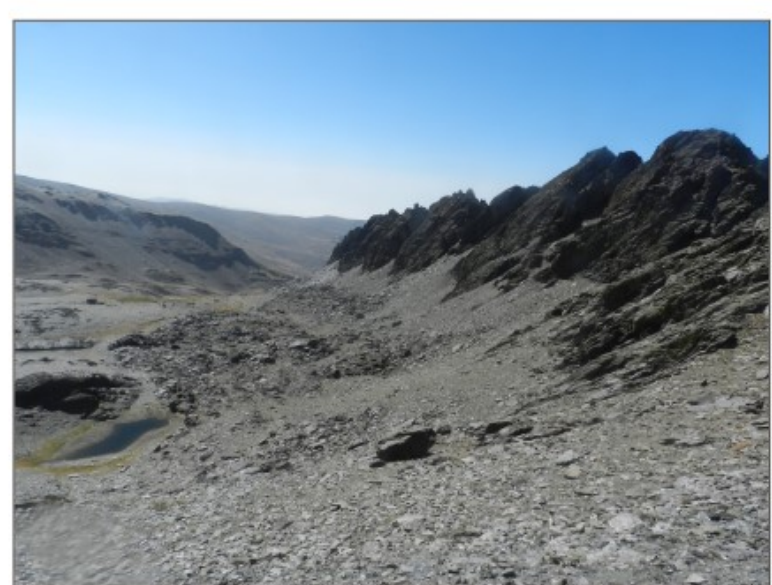

Deglaciation (protalus lobes; Sierra Nevada)

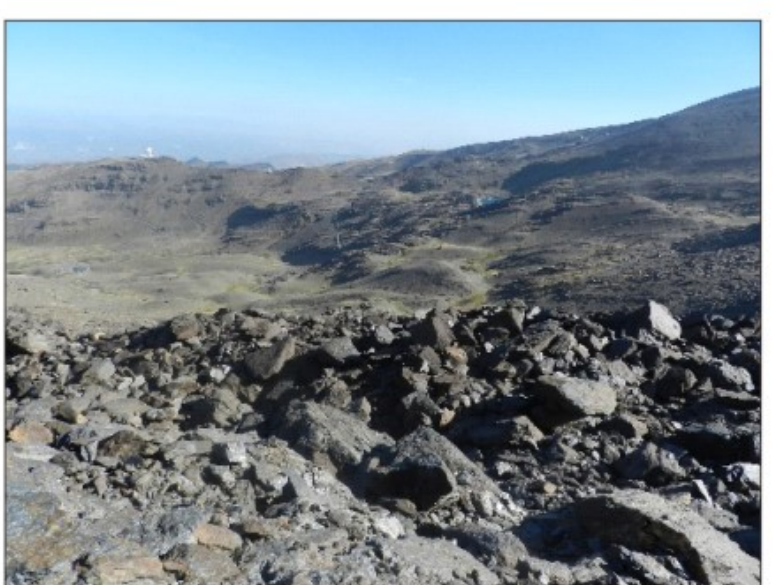

Holocene (rock glacier; Sierra Nevada)

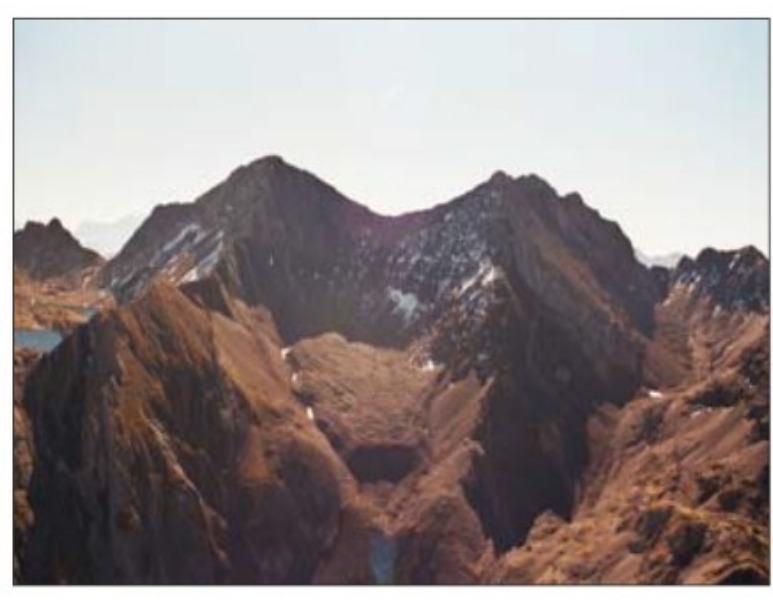

LIA (rock glacier; Pyrenees)

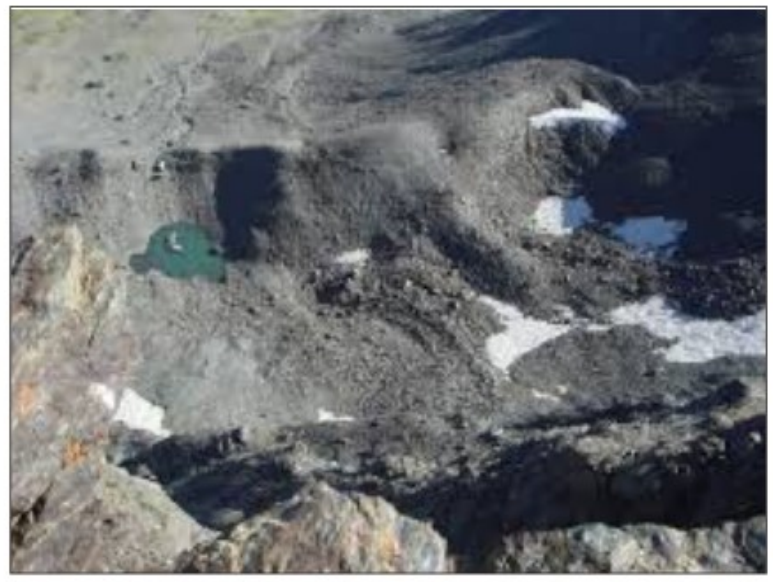

Present-day (rock glacier; Sierra Nevada) 


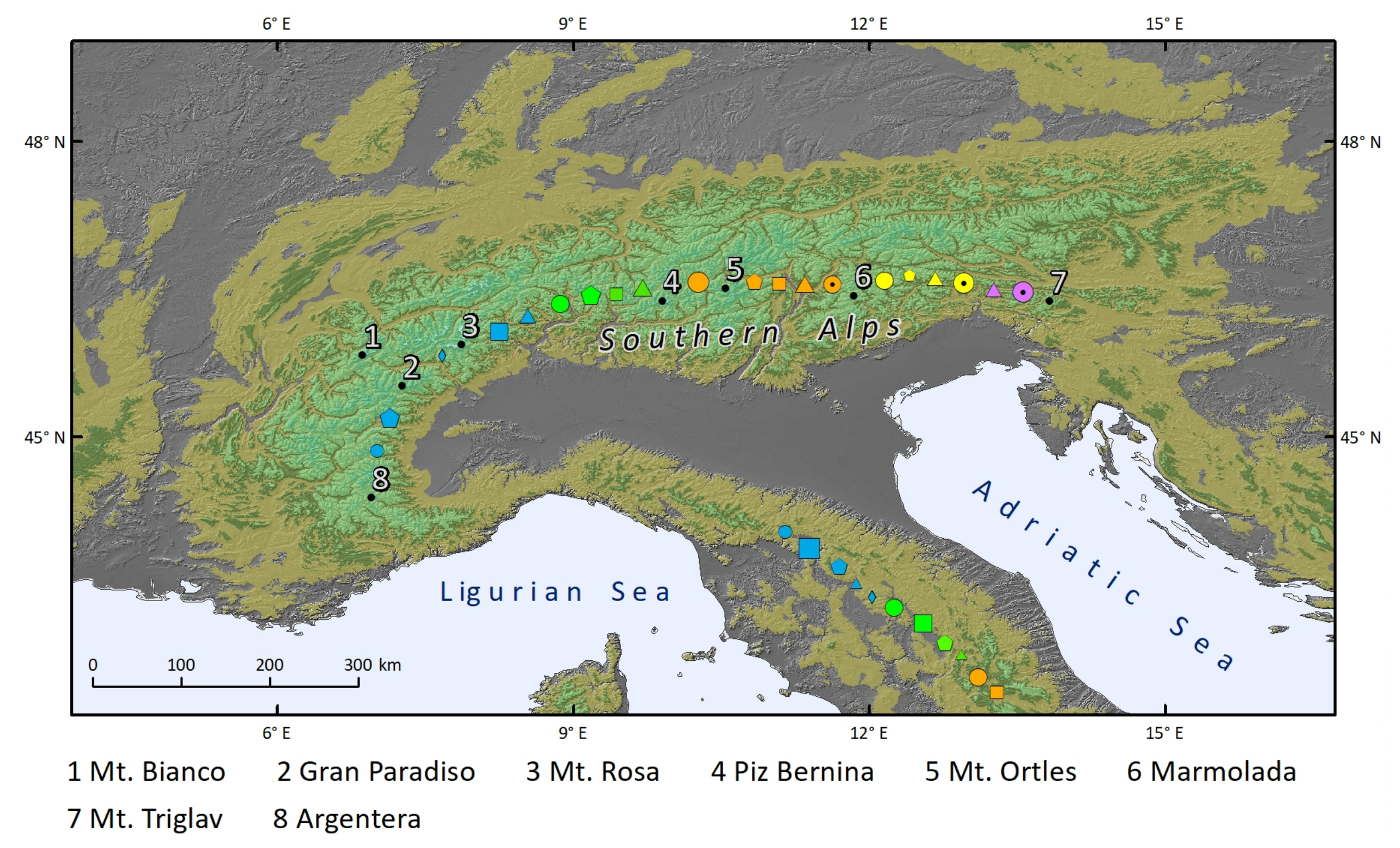




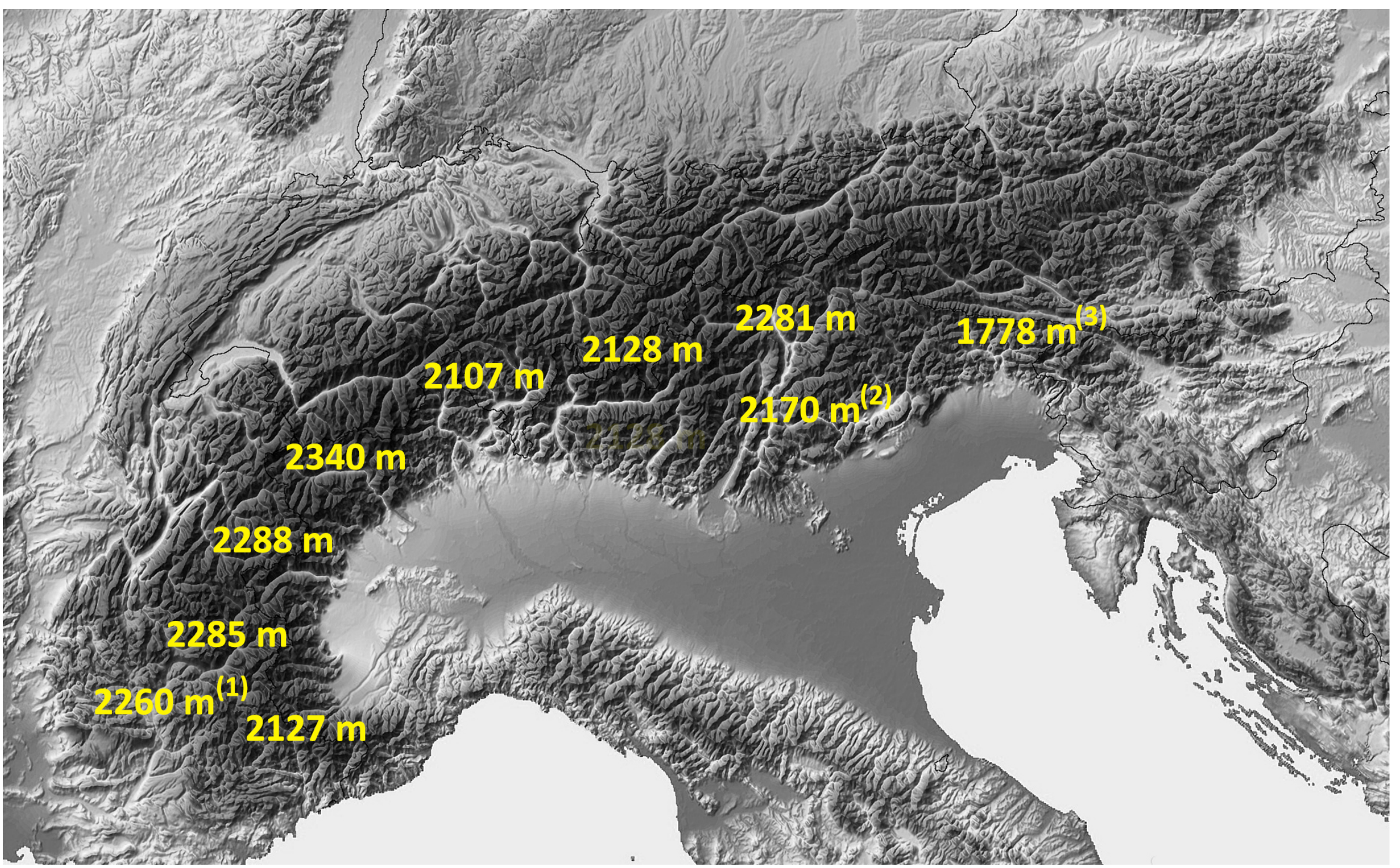




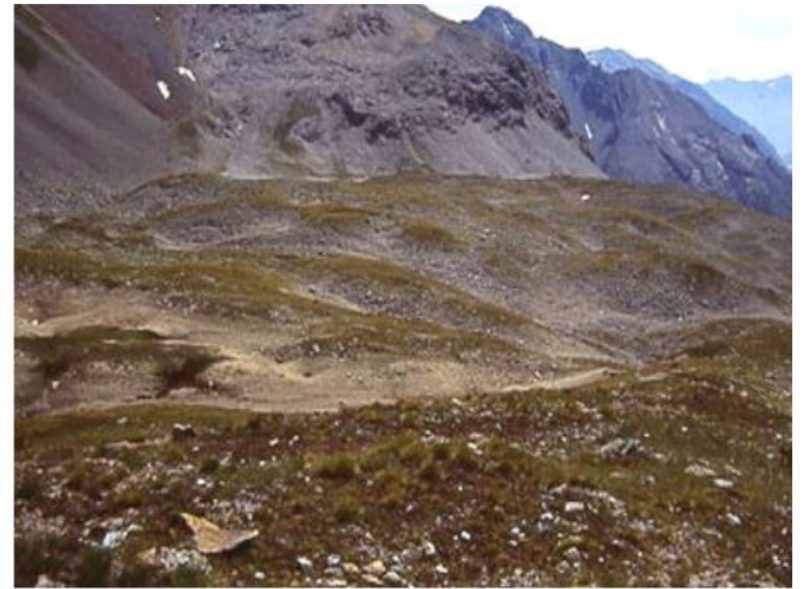

LGM (relict rock glacier, central Alps) Photo: M.Guglielmin

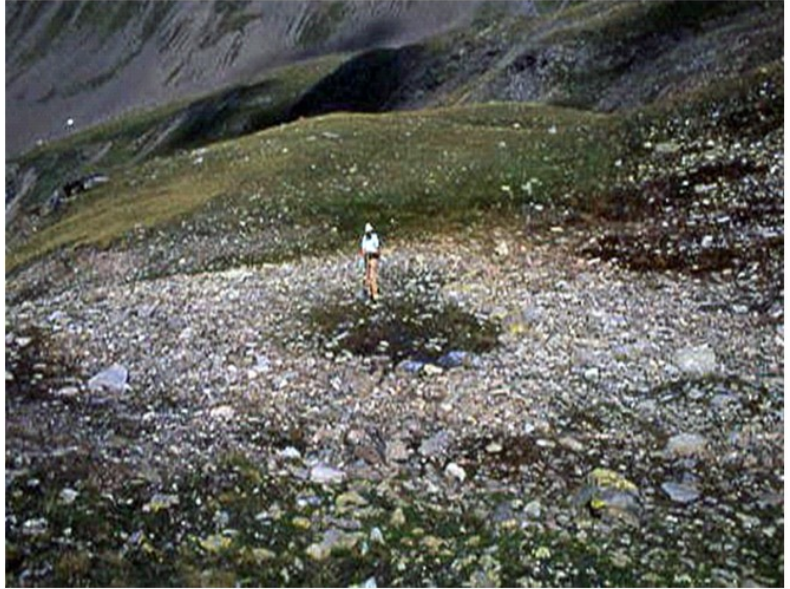

Deglaciation (patterned ground; central Alps) Photo: M. Guglielmin

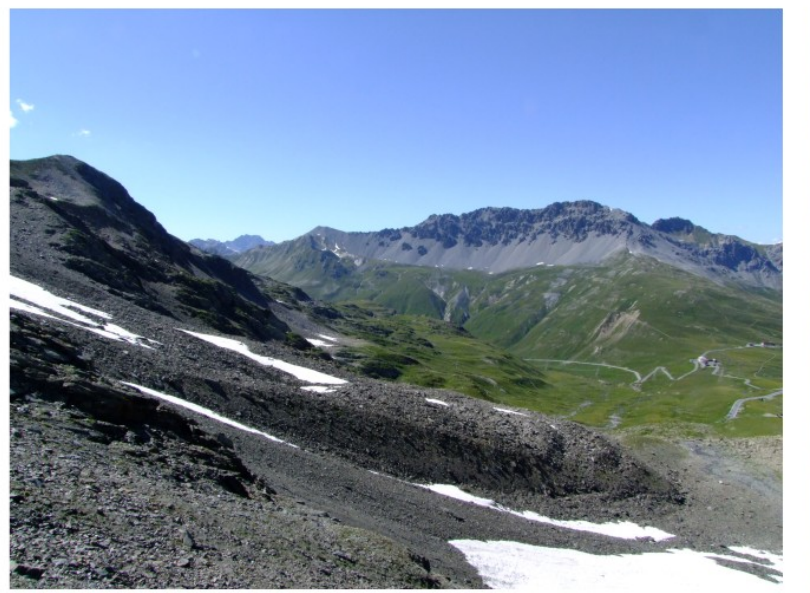

Holocene (active rock glacier; central Alps) Photo: R.R.Colucci

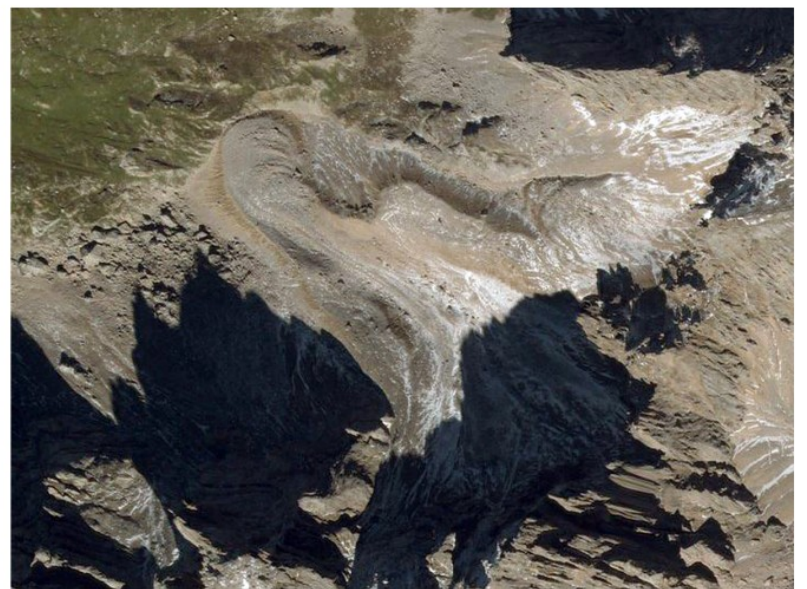

LIA (active rock glacier; Dolomites) aerial view from free BingMaps

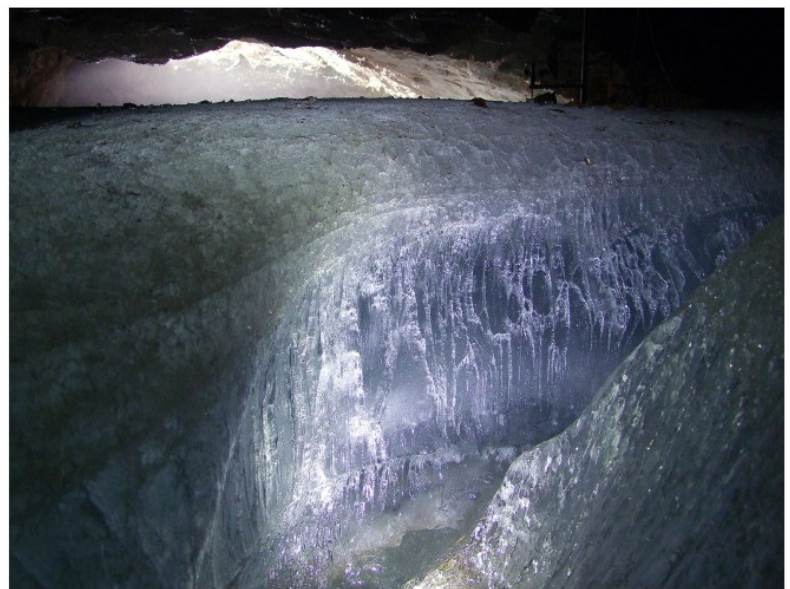

Present-day (ground ice, ice cave; eastern Alps Photo: R.R.Colucci) 


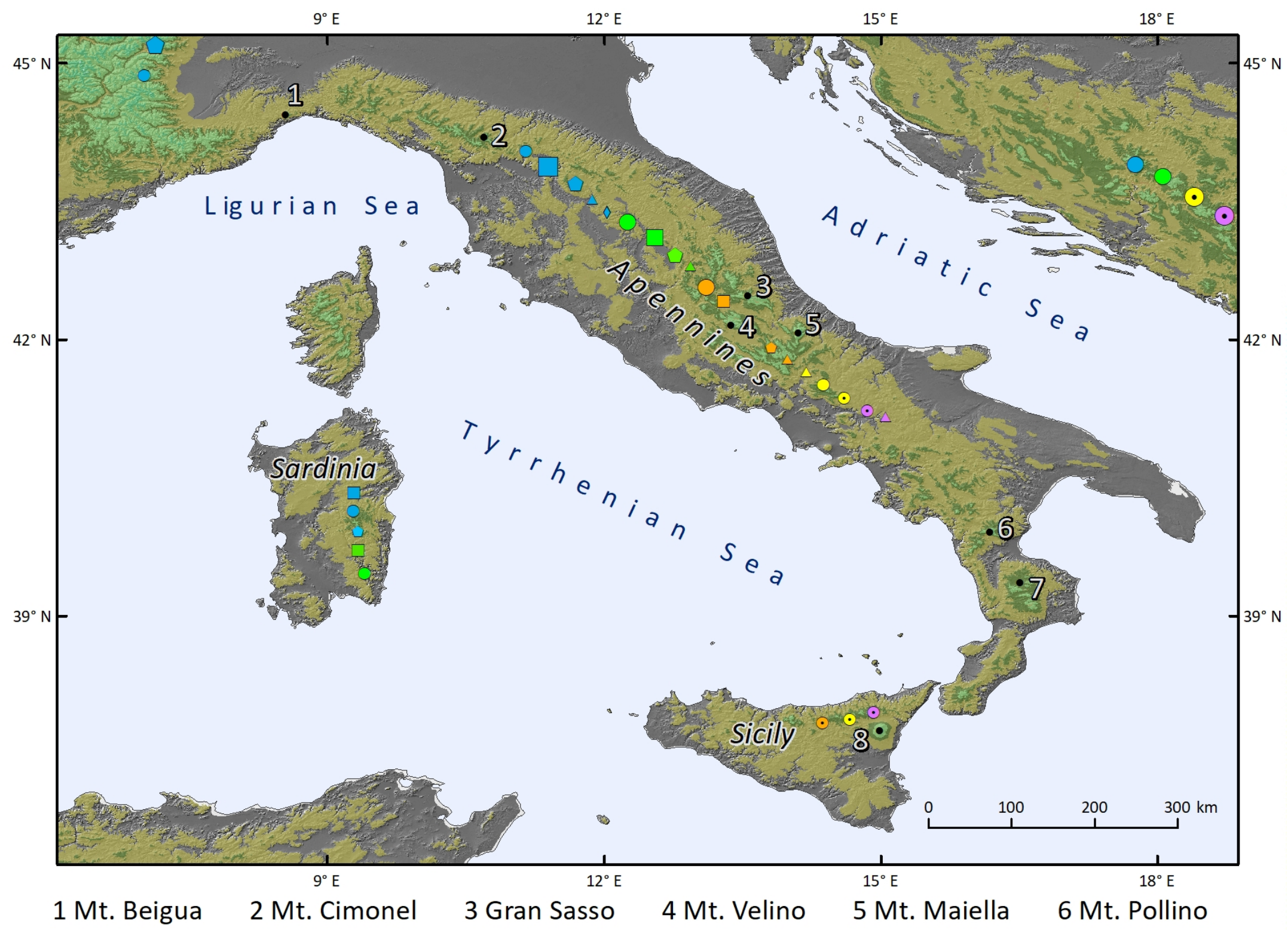

7 Mt. Sila 8 Mt. Etna 


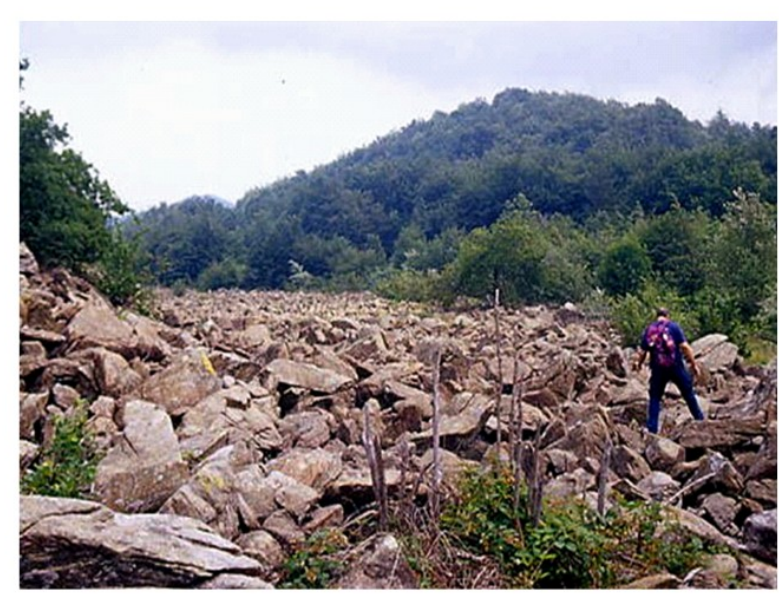

LGM (block stream; Apennines Photo: M.Guglielmin)

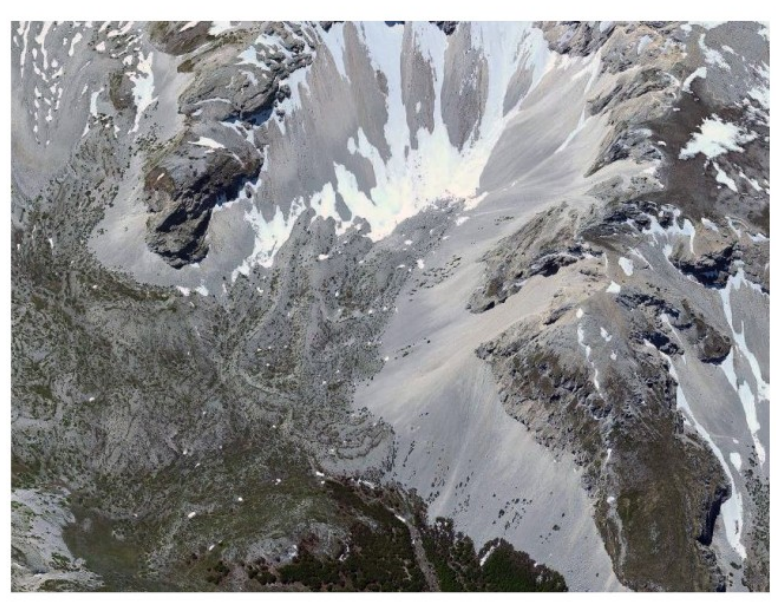

Deglaciation (relict rock glacier; Apennines) aerial view from free BingMaps

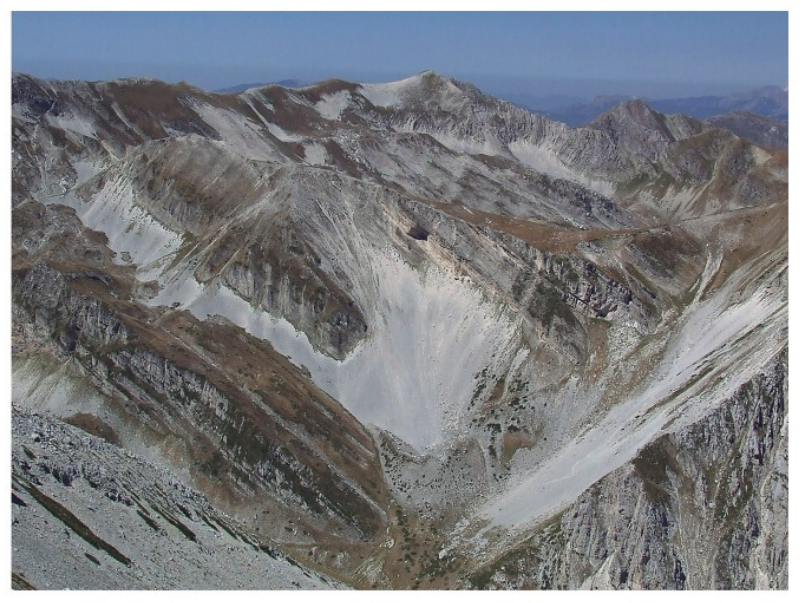

Holocene (protalus lobe; Apennines) Photo: R.R.Colucci

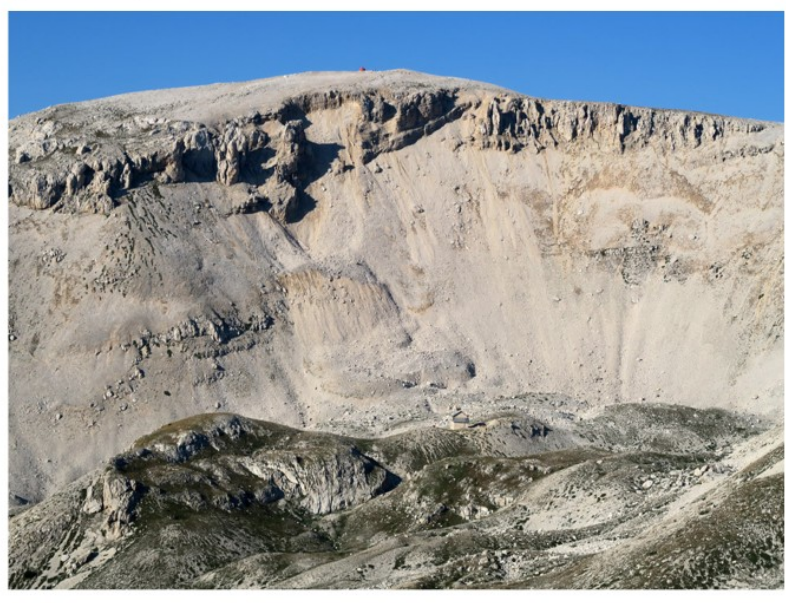

LIA (active rock glacier; Apennines) Photo: M.Leoni

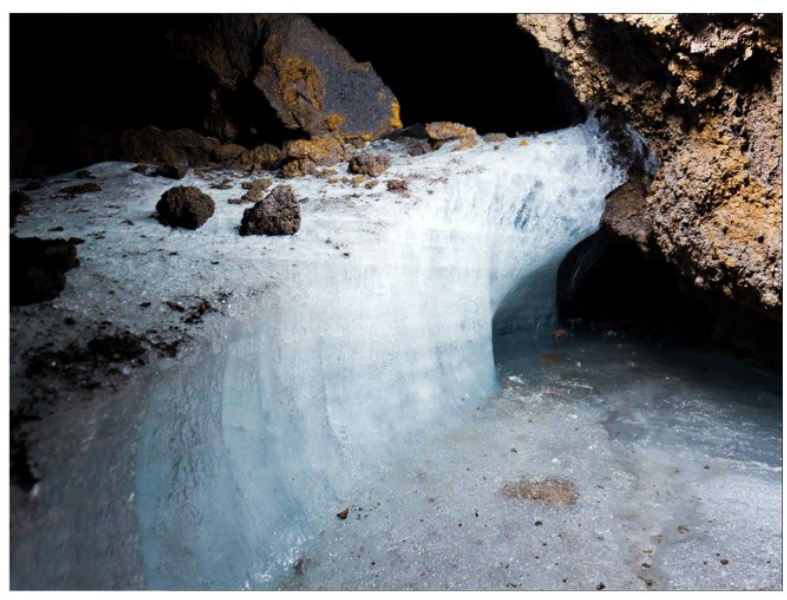

Present-day (ground ice, ice cave; Sicily) Photo: M.Restivo 


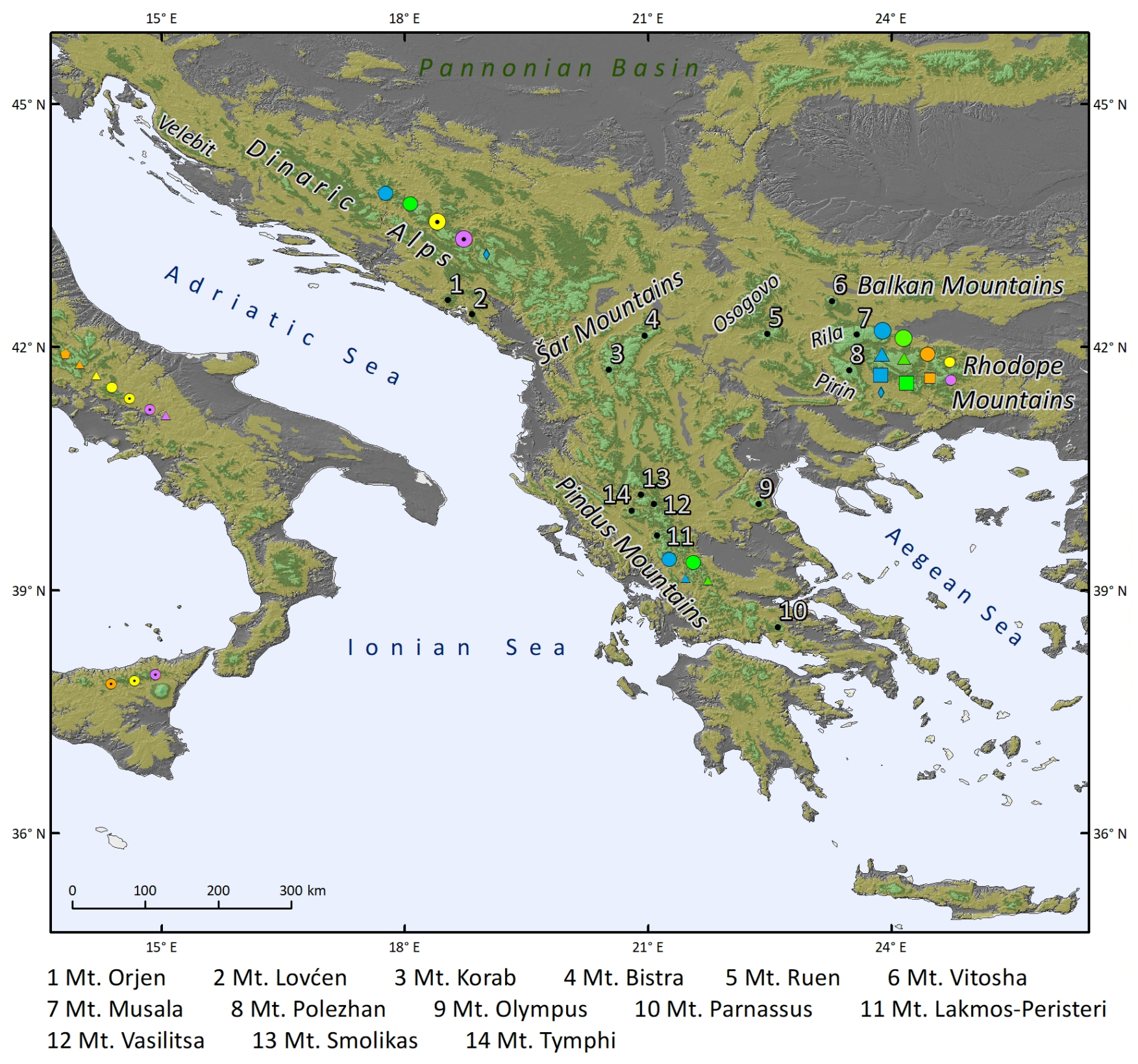




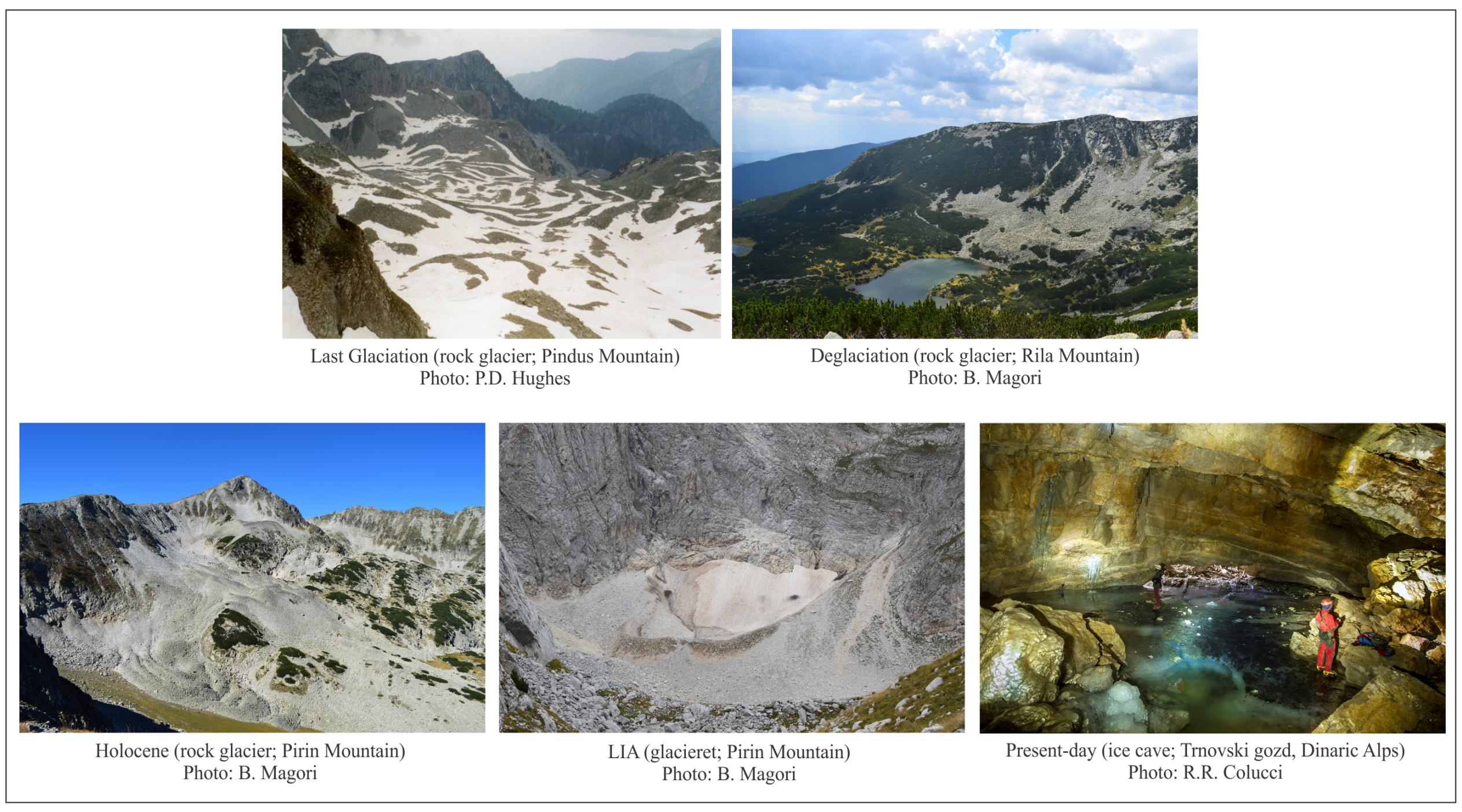




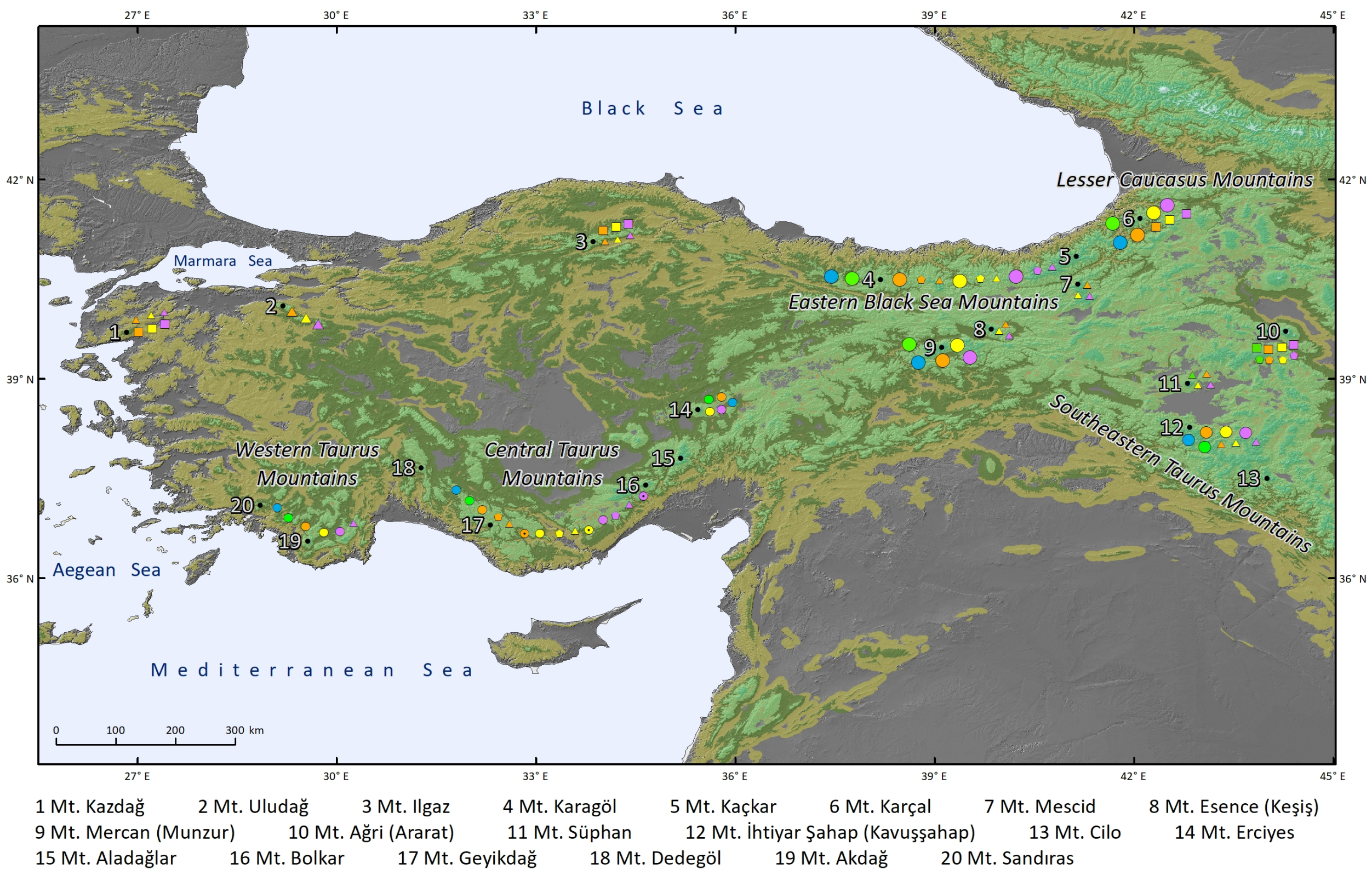



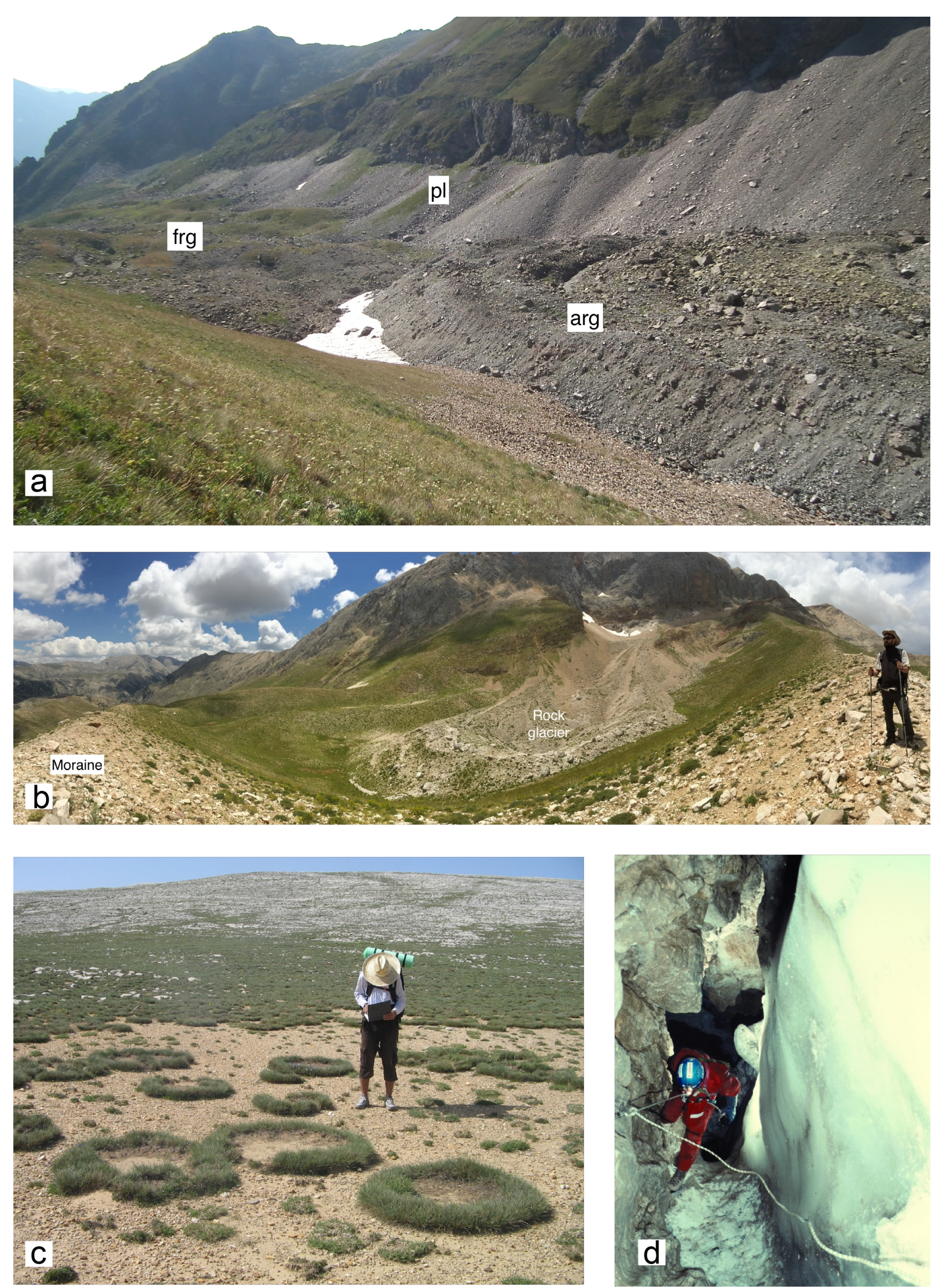


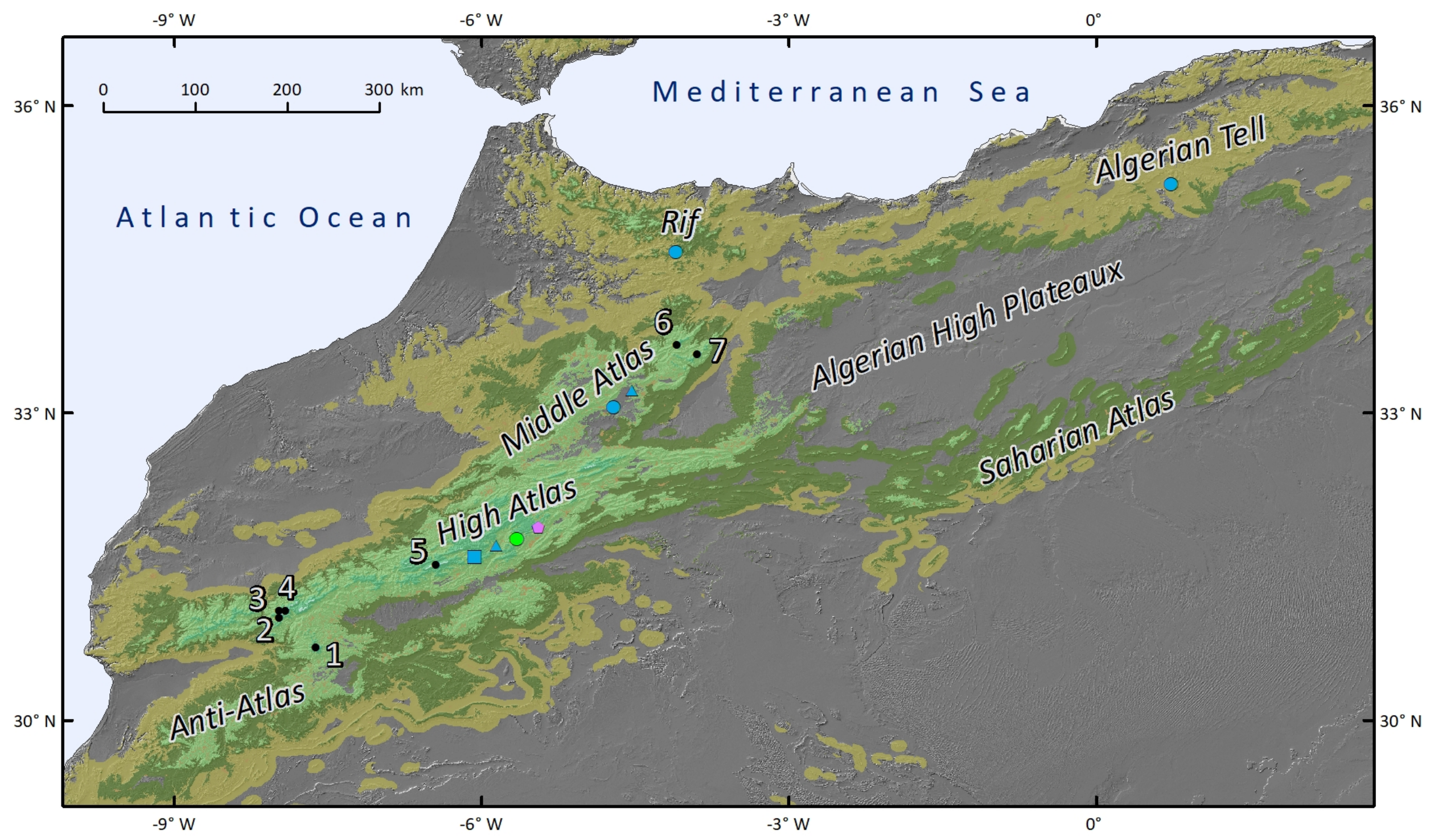

1 Djebel Sirwa 2 louzagner 3 Tazaghart 4 Djebel Toubkal 5 M'Goun 6 Djebel Bou Iblane 7 Djebel Bou Naceur 


Table 1. Study areas of this research together with the main massifs and altitude distribution of present-day climate conditions and elevation of the lower periglacial belt.

\begin{tabular}{|c|c|c|c|c|}
\hline Region & Mountain range (highest peaks, $\mathrm{m}$ asl) & $\begin{array}{l}\text { Annual } \\
\text { precipitation (mm) }\end{array}$ & $\begin{array}{l}\text { *Altitude of } 0^{\circ} \mathrm{C} \\
\text { isotherm ( } \mathrm{m} \text { asl) }\end{array}$ & $\begin{array}{c}\text { Lower altitude } \\
\text { periglacial belt }(\mathbf{m})\end{array}$ \\
\hline \multirow{6}{*}{$\begin{array}{l}\text { Iberian } \\
\text { Peninsula }\end{array}$} & Pyrenees (Aneto, 3404; Posets, 3371) & $1200-2500$ & $2800-2900$ & $2100(\mathrm{~N}), 2300(\mathrm{~S})$ \\
\hline & $\begin{array}{c}\text { Cantabrian Mountains (Torre Ceredo, 2650; Torre del } \\
\text { Llambrión, 2642) }\end{array}$ & $2000-2500$ & $2400-2500$ & $1900(\mathrm{~N}), 2100(\mathrm{~S})$ \\
\hline & NW ranges (Peña Trevinca, 2127) & $1800-2200$ & $2400-2500$ & $1900(\mathrm{~N}), 2100(\mathrm{~S})$ \\
\hline & Central Range (Pico Almanzor, 2591) & $1200-2000$ & $2400-2500$ & $2100(\mathrm{~N}), 2300(\mathrm{~S})$ \\
\hline & Iberian Range (Moncayo, 2313; San Lorenzo) & $1000-1500$ & $2400-2500$ & $2100(\mathrm{~N}), 2300(\mathrm{~S})$ \\
\hline & Betic Range (Mulhacén, 3478; Veleta, 3398) & $600-900$ & 3400 & $2500(\mathrm{~N}), 2650(\mathrm{~S})$ \\
\hline \multirow{4}{*}{$\begin{array}{l}\text { Southern } \\
\text { Alps }\end{array}$} & Western Alps (Monte Bianco, 4810; Monte Rosa, 4634) & $800-2500$ & $2400-2500$ & $2200(\mathrm{~N}) ; 2500(\mathrm{~S})$ \\
\hline & Central Alps (Piz Bernina, 4059; Cima de Piazzi, 3439) & $700-2300$ & $2300-2400$ & $2200(\mathrm{~N}) ; 2400(\mathrm{~S})$ \\
\hline & Eastern Alps (Ortles, 3905; Triglav, 2869) & $1000-3300$ & $2400-2500$ & $2100(\mathrm{~N}) ; 2400(\mathrm{~S})$ \\
\hline & Maritime Alps (Argentera, 3297) & $800-1800$ & $2500-2600$ & $2200(\mathrm{~N}) ; 2500(\mathrm{~S})$ \\
\hline \multirow{3}{*}{$\begin{array}{l}\text { Italian } \\
\text { Peninsula }\end{array}$} & Northern Apennine (Cimone, 2165) & $1100-2300$ & - & - \\
\hline & Central Apennine(Gran Sasso, 2912; La Majella, 2793) & $700-1300$ & $2400-2500$ & $2200(\mathrm{~N})$ \\
\hline & Southern Apennine (Pollino, 2233; Sila, 1930) & $700-1600$ & - & - \\
\hline \multirow{7}{*}{$\begin{array}{c}\text { Balkan } \\
\text { Peninsula }\end{array}$} & Dinaric Alps (Maja Jezercë, 2694) & $1500-4900$ & $2000-2500$ & \\
\hline & Pirin Mountains (Vihren, 2914) & 610 & 2770 & \\
\hline & Stara Planina (Botev, 2376) & 1260 & 2400 & \\
\hline & Rila Mountains (Musala, 2925) & $>1000$ & 2400 & \\
\hline & Pindus Mountains (Smolikas, 2637) & 1720 & 2870 & \\
\hline & Mount Olympus (Mount Olympus , 2917) & 810 & 2450 & \\
\hline & Šar Mountains (Titov Vrv, 2747) & 1300 & - & \\
\hline \multirow{13}{*}{ Anatolia } & $\begin{array}{l}\text { Western Taurus Mountains (Akdă̆, 3016; Dedegöl, } \\
\text { 2992; Geyikdağ, 2877) }\end{array}$ & $700-950$ & $3200-3400$ & 2500 \\
\hline & $\begin{array}{l}\text { Central Taurus Mountains (Aladağlar, 3756; Bolkar, } \\
\text { 3524) }\end{array}$ & 800 & 3200 & 3200 \\
\hline & Southeastern Taurus Mountains (Cilo, 4135) & $600-700$ & $3400-3600$ & $?$ \\
\hline & Eastern Black Sea Mountains (Kaçkar, 3937) & $900-1000$ & $3000-3100$ & $1800-2200(\mathrm{~N})$ \\
\hline & Karçal (Lesser Caucasus Mts.) (Karçal, 3932) & $900-1000$ & 2800 & 2100 \\
\hline & Kazdağ (Kazdăg, 1774) & 900 & 2800 & $1350(\mathrm{~N})$ \\
\hline & Uludağ (Uludağ, 2543) & 1300 & 2600 & 1900 \\
\hline & Ilgaz (Ilgaz, 2546) & 800 & 2600 & $?$ \\
\hline & Esence (Keşiş, 3549) & $750-800$ & 3200 & $2500(\mathrm{~N})$ \\
\hline & Mercan (Munzur, 3463) & 700 & $3200-3300$ & $?$ \\
\hline & Mescid (3239) & 700 & 3100 & 2650 \\
\hline & Erciyes (Erciyes, 3917) & $600-750$ & $3000-3100$ & 2950 \\
\hline & Ağrı (Ararat, 5137) & $700-900$ & 3500 & 3000 \\
\hline \multirow{8}{*}{$\begin{array}{l}\text { Northern } \\
\text { Africa }\end{array}$} & Hoggar (Mount Tahat, 2981) & 145 & 4904 & NA \\
\hline & Tibesti (Emi Koussi, 3445) & 11 & 4516 & NA \\
\hline & Rif Mountains (Tidirhine, 2456) & $500-2168$ & 3027 & NA \\
\hline & Middle Atlas (Djebel Bou Naceur, 3340) & $200->1100$ & 3565 & 2500 \\
\hline & High Atlas (Djebel Toubkal, 4167) & $200->600$ & 3733 & $2500-3000$ \\
\hline & Algerian Tell (Djurdjura, 2308) & $>1500$ & 3254 & $1500-1800(?)$ \\
\hline & Algerian High Plateaux (Djebel Guerioun, 1729) & $>700$ & 3340 & NA \\
\hline & Aurès Massif (Aurès, 2324) & $300-450$ & 3340 & 2300 \\
\hline
\end{tabular}

*Extrapolated used on a lapse rate of $0.6 \mathrm{C}$ per $100 \mathrm{~m}$ altitude. 
Table 2. Periglacial processes and landforms in the Iberian Peninsula since the Last Glaciation until today.

\begin{tabular}{|c|c|c|c|c|}
\hline Phase & Areas & Environment: landforms and processes & $\begin{array}{l}\text { Chronology } \\
\text { (ka BP) }\end{array}$ & References \\
\hline \multirow{7}{*}{$\begin{array}{c}\text { Last } \\
\text { Glaciation }\end{array}$} & Pyrenees & $\begin{array}{l}\text { Non-glaciated summit plateaus: patterned ground with meter-sized sorted circles } \\
\text { Mid-low slopes: rock glaciers, block streams } \\
\text { Valleys: fragipan and permafrost evidences }>1130 \mathrm{~m} \\
\text { Stratified debris above } 800-1000 \mathrm{~m}\end{array}$ & $\begin{array}{l}>32 \\
18-20 \\
20-22\end{array}$ & $\begin{array}{l}\text { Gómez-Ortiz and Serrat (1979), Gómez-Ortiz (1980), Chueca et al. } \\
\text { (1994), Peña et al. (1998, 2000), Serrano (1998), García-Ruiz et al. } \\
\text { (2001, 2005), Chueca and Julián (2008), Boixadera et al. (2008) }\end{array}$ \\
\hline & $\begin{array}{l}\text { Cantabrian } \\
\text { Mountains }\end{array}$ & $\begin{array}{l}\text { Summit plateaus: patterned ground with sorted circles } \\
\text { Mid slopes > } 1300 \mathrm{~m} \text { : rock glaciers, block streams, blockfields } \\
\text { Stratified debris above } 400 \mathrm{~m} \\
\text { Ice wedge cast above } 700 \mathrm{~m}\end{array}$ & & $\begin{array}{l}\text { García de Celis (1991, 2002), Ugarte (1992), Pérez-Alberti et al. (1994), } \\
\text { Pérez-Alberti and Rodríguez-Gutián (1993), Castañón and Frochoso } \\
\text { (1994, 1998), Valcárcel (1998), Pérez-Alberti and Valcárcel (2000), } \\
\text { Válcárcel and Pérez-Alberti (2002), González-Gutiérrez (2002), } \\
\text { González-Trueba (2007a,b), Pellitero (2009, 2012), Rodríguez-Pérez } \\
\text { (2009), Santos-González (2010), Pellitero et al. (2011), Serrano et al. } \\
\text { (2013), Ruiz-Fernández (2013) }\end{array}$ \\
\hline & NW ranges & Slopes $>700 \mathrm{~m}$ : rock glaciers, block streams; $>1500 \mathrm{~m}$ : block slopes & $>44$ to 16 & $\begin{array}{l}\text { Pérez-Alberti (1979), Pérez-Alberti and Rodríguez-Guitián (1993), } \\
\text { Pérez-Alberti et al. (1994, 1998, 2011), Valcárcel (1998), Valcárcel } \\
\text { (1998), Valcárcel et al. (1998), Martínez-Cortizas et al. (1999), Valcárcel } \\
\text { and Pérez-Alberti (2002), Hall-Riaza et al. (2016) }\end{array}$ \\
\hline & Central Range & $\begin{array}{l}\text { Non-glaciated summit plateaus: blockfields, tors } \\
\text { Mid slopes > } 1500 \mathrm{~m} \text { : scarce rock glaciers, block slopes, solifluction } \\
\text { Low slopes } 700-1200 \mathrm{~m} \text { : periglacial slope deposits (stratified and head), with } \\
\text { possible permafrost conditions }\end{array}$ & $<30$ & $\begin{array}{l}\text { Ontañón and Asensio-Amor (1973), Daveau (1973, 1978) Daveau et al. } \\
\text { (1997), Ontañón (1985), Sanz-Herráiz (1988), Ferreira et al. (2000), } \\
\text { Palacios et al. (2003), Vieira (2004), Carrasco et al. (2012) }\end{array}$ \\
\hline & Iberian Range & $\begin{array}{l}\text { High slopes }>1800 \mathrm{~m} \text { : block streams, rock glaciers } \\
\text { Slopes > } 1100 \mathrm{~m} \text { : stratified debris } \\
\text { Non-glaciated summit plateaus: patterned ground, cryoturbation, blockfields }\end{array}$ & & $\begin{array}{l}\text { Thornes (1968), Asensio-Amor (1974), Gutiérrez-Elorza and Peña } \\
\text { (1977), García-Ruiz (1979), Pellicer (1980), Ortigosa (1986), Arnáez } \\
\text { (1987), Sanz and Pellicer (1994), Peña and Lozano (1998), Arnáez and } \\
\text { García-Ruiz (2000) }\end{array}$ \\
\hline & Sierra Nevada & $\begin{array}{l}\text { Non-glaciated summit plateaus }>3000 \mathrm{~m} \text { : development of patterned ground with } \\
\text { meter-sized sorted circles } \\
\text { Non-glaciated high slopes }(2500 \mathrm{~m}) \text { : formation of three rock glacier }\end{array}$ & $20-30$ & $\begin{array}{l}\text { Messerli (1965), Gómez-Ortiz (1987, 2002), Simón et al. (2000), } \\
\text { Gómez-Ortiz and Salvador (1992), Gómez-Ortiz et al. (1994), Oliva } \\
\text { (2011), Palma et al. (2017) }\end{array}$ \\
\hline & Lowlands & Ice-wedges in Pleistocene fluvial terraces (200-1000 m) & & $\begin{array}{l}\text { Badorrey et al. (1970), Asensio-Amor and González-Martín (1974), } \\
\text { Serrano et al. (2010a) }\end{array}$ \\
\hline \multirow{3}{*}{ Deglaciation } & Pyrenees & $\begin{array}{l}\text { Glacial cirques and summits: rock glacier formation }>2250 \mathrm{~m} \text {, with widespread } \\
\text { permafrost }>2490 \mathrm{~m} \text {, patterned ground formation } \\
\text { Glacial cirques and summits: rock glaciers becoming gradually inactive }<2300 \mathrm{~m} \\
\text { and new ones forming }>2350 \mathrm{~m} \text {, permafrost widespread }>2525 \mathrm{~m} \\
\text { Stratified debris }>700 \mathrm{~m}\end{array}$ & $15-17$ & $\begin{array}{l}\text { Gómez-Ortiz (1980), Soutadé (1980), Chueca et al. (1994), Serrano } \\
\text { (1998), García-Ruiz et al (2000, 2001, 2005, 2015, 2016), Hirsch and } \\
\text { Raab (2014), Palacios et al. (2015) }\end{array}$ \\
\hline & $\begin{array}{l}\text { Cantabrian } \\
\text { Mountains }\end{array}$ & $\begin{array}{l}\text { Summit plateaus: patterned ground formation } \\
\text { Glacial cirques: rock glaciers, block streams }\end{array}$ & & $\begin{array}{l}\text { Alonso (1989), Redondo et al. (2002, 2004, 2010), González-Trueba } \\
\text { (2007a,b), Alonso and Trombotto (2009), Rodríguez-Pérez (1995, 2009), } \\
\text { Santos-González (2010), Pellitero et al. (2011), Pellitero (2012), Serrano } \\
\text { et al. (2013), Ruiz-Fernández (2013) }\end{array}$ \\
\hline & NW ranges & High slopes: rock glaciers & & Valcárcel (1998), Valcárcel and Pérez-Alberti (2002) \\
\hline
\end{tabular}




\begin{tabular}{|c|c|c|c|c|}
\hline & Central Range & $\begin{array}{l}\text { Glacial cirques: formation of rock glaciers } \\
\text { Slopes: solifluction lobes }\end{array}$ & $15-17$ & Palacios et al. (2011a,b, 2012), Carrasco et al. $(2012,2015)$ \\
\hline & Iberian Range & Glacial cirques: formation of rock glaciers and block streams & & $\begin{array}{l}\text { García-Ruiz (1979), Ortigosa (1986), Pellicer (1980), Sanz and Pellicer } \\
\text { (1994), García-Ruiz et al. (1998) }\end{array}$ \\
\hline & Sierra Nevada & Glacial cirques: formation of rock glaciers and protalus lobes & $12.8-7.4$ & $\begin{array}{l}\text { Palade et al. (2011), Gómez-Ortiz et al. (2012a, 2013), Oliva (2009), } \\
\text { Oliva et al. (2014), Palacios et al. (2016) }\end{array}$ \\
\hline \multirow{3}{*}{ Holocene } & Pyrenees & $\begin{array}{l}\text { Glacial cirques and high slopes: degradation of permafrost in the highest areas } \\
\text { and probable complete deglaciation, elevation rise of snow patches, formation of } \\
\text { rock glaciers, development of ice caves }\end{array}$ & Mid Holocene & $\begin{array}{l}\text { Grove and Gellatly (1995), Serrano (1998), García-Ruiz et al. (2005), } \\
\text { Serrano et al. (2010b, 2011), Sancho et al. (2016) }\end{array}$ \\
\hline & $\begin{array}{l}\text { Cantabrian } \\
\text { Mountains }\end{array}$ & Glacial cirques: active rock glaciers becoming gradually inactive & Cold stages & $\begin{array}{l}\text { Alonso and Trombotto (2009), Pellitero et al. (2011), Serrano et al. } \\
(2013)\end{array}$ \\
\hline & Sierra Nevada & Glacial cirques: rock glaciers and protalus lobes becoming gradually inactive & Until 7.4 & Gómez-Ortiz et al. (2012a, 2013), Oliva and Gómez-Ortiz (2011) \\
\hline \multirow{3}{*}{ LIA } & Pyrenees & $\begin{array}{l}\text { Glacial cirques and high slopes: glacial advance, greater abundance of snow } \\
\text { patches, formation and reactivation of rock glaciers and protalus lobes, } \\
\text { permafrost }>2560 \mathrm{~m} \text {, patterned ground formation, development of ice caves }\end{array}$ & $\begin{array}{l}\text { XIV-XIX } \\
\text { centuries }\end{array}$ & $\begin{array}{l}\text { Martínez de Pisón and Arenillas (1988), García-Ruiz et al. (1988), } \\
\text { Copons and Bordonau (1994), Grove and Gellatly (1995), Julián and } \\
\text { Chueca (1998), Lugon et al. (2004), Serrano (1998), Serrano et al. (2001, } \\
\text { 2002), García-Ruiz and Martí-Bono (2001), Chueca et al. (2005), } \\
\text { González-Trueba et al. (2008); Fernandes et al. (2017), Leunda et al. } \\
\text { (2015), Bartolomé et al. (2015), Sancho et al. (2016) }\end{array}$ \\
\hline & $\begin{array}{l}\text { Cantabrian } \\
\text { Mountains }\end{array}$ & $\begin{array}{l}\text { Highest cirques }>2200 \mathrm{~m} \text { : development of small glaciers, greater abundance of } \\
\text { snow patches, frost mounds, probable permafrost }>2400 \mathrm{~m} \text { in northern cirques } \\
\text { with seasonal ground ice above } 1600 \mathrm{~m} \text {, development of ice caves }\end{array}$ & $\begin{array}{l}\text { XIV-XIX } \\
\text { centuries }\end{array}$ & González-Trueba (2007a,b), Serrano et al. (2013), Pellitero (2014) \\
\hline & Sierra Nevada & $\begin{array}{l}\text { Highest cirques }>3000 \mathrm{~m} \text { : presence of glaciers in the highest northern cirques, } \\
\text { more extensive snow fields }>2500 \mathrm{~m} \text {, possible permafrost conditions near } \\
\text { glaciers }\end{array}$ & $\begin{array}{l}\text { XVII to XIX } \\
\text { centuries }\end{array}$ & $\begin{array}{l}\text { Gómez-Ortiz and Plana-Castellví (2006), Gómez-Ortiz et al. (2009, } \\
\text { 2012b), Oliva and Gómez-Ortiz (2012), Oliva et al. (2011) }\end{array}$ \\
\hline \multirow{3}{*}{ Present-day } & Pyrenees & $\begin{array}{l}\text { Cirques and high slopes } \geq 2500 \mathrm{~m} \text { : probable permafrost above } \sim 2630 \mathrm{~m}(\mathrm{~N}), \\
2800 \mathrm{~m}(\mathrm{~S}), \text { active rock glaciers above } 2510 \mathrm{~m} \text {, protalus lobes, ice patches, } \\
\text { active ice cave processes, frost mounds, patterned ground formation }\end{array}$ & $\begin{array}{l}\text { since the late } \\
\text { XIX century }\end{array}$ & $\begin{array}{l}\text { Soutadé (1980), Gómez-Ortiz (1980), Höllermann (1985), Chueca } \\
\text { (1992), Serrano and Agudo (1998, 2004), Serrano et al. (1999, 2000, } \\
\text { 2001, 2002, 2006, 2009, 2010b, 2010c, 2011a), Chueca et al. (2000), } \\
\text { Julián and Chueca (2007), Feuillet (2010), Feuillet and Mercier (2012), } \\
\text { Bartolomé et al. (2015), González-García (2014), García-Ruiz et al. } \\
\text { (2015), González-García et al. (2017) }\end{array}$ \\
\hline & $\begin{array}{l}\text { Cantabrian } \\
\text { Mountains }\end{array}$ & $\begin{array}{l}\text { Highest cirques }>2200 \mathrm{~m} \text { : degradation of buried ice and sporadic permafrost } \\
\text { (e.g. Jou Negro, Forcadona), ice patches, active ice cave processes, frost mounds }\end{array}$ & $\begin{array}{l}\text { since the late } \\
\text { XIX century }\end{array}$ & $\begin{array}{l}\text { Castañón and Frochoso (1998), González-Trueba (2007a,b), Serrano et } \\
\text { al. (2011b), Ruiz-Fernández (2013), Gómez-Lende et al. (2014), Ruiz- } \\
\text { Fernández et al. (2014), Pisabarro et al. (2016) }\end{array}$ \\
\hline & Sierra Nevada & $\begin{array}{l}\text { Highest cirques }>3000 \mathrm{~m} \text { : formation of rock glaciers, degradation of buried ice } \\
\text { and permafrost, with subsidence and collapses of the rock glacier of the Veleta } \\
\text { cirque (accelerating during the last decade) }\end{array}$ & $\begin{array}{l}\text { since the late } \\
\text { XIX century }\end{array}$ & $\begin{array}{l}\text { Gómez-Ortiz et al. (2001, 2004, 2014), Salvador-Franch et al. (2010, } \\
\text { 2011), Tanarro et al. (2010), Oliva et al. (2016b) }\end{array}$ \\
\hline
\end{tabular}


Table 3. Periglacial processes and landforms in the Southern Alps since the Last Glaciation until today.

\begin{tabular}{|c|c|c|c|c|}
\hline Phase & Areas & Environment: landforms and processes & $\begin{array}{c}\text { Chronology } \\
\text { (ka BP) }\end{array}$ & References \\
\hline \multirow{3}{*}{$\begin{array}{c}\text { Last } \\
\text { Glaciation }\end{array}$} & Po plain & Cryoturbations, stratified slope deposits, loess cover & 35-LGM & Cremaschi et al. (2005), Guglielmin (unpublished data) \\
\hline & Piedmont & Block streams, blockfields & LGM & Fioraso and Spagnolo, (2009), Paro (2011) \\
\hline & Julian Alps & Rock glacier at $1076 \mathrm{~m}$ on average & LGM & Colucci et al. (2016a) \\
\hline \multirow{3}{*}{ Deglaciation } & Southern Alps & Rock glaciers at $2260 \mathrm{~m}$ on average & YD & Bornet et al. (2014) \\
\hline & Western Alps & Rock glaciers at $2340-2260 \mathrm{~m}$ on average & YD & Guglielmin and Smiraglia (1997), Bornet et al. (2014) \\
\hline & $\begin{array}{l}\text { Central Alps } \\
\text { Julian Alps }\end{array}$ & $\begin{array}{l}\text { Rock glaciers at } 2280-2160 \mathrm{~m} \text { on average } \\
\text { Rock glaciers at } 1778 \mathrm{~m} \text { on average }\end{array}$ & $\begin{array}{l}\text { YD } \\
\text { YD }\end{array}$ & $\begin{array}{l}\text { Guglielmin and Smiraglia (1997), Seppi et al. (2012), Scotti et al. (2013), } \\
\text { Colucci et al. (2016a) }\end{array}$ \\
\hline \multirow[b]{2}{*}{ Holocene } & Western Alps & Rock glaciers at different altitudes & & Dramis et al. (2003) \\
\hline & Central Alps & Rock glaciers at different altitudes & $\begin{array}{l}8.9,2.2 \\
2.7-2.9 \\
0.9-1.4\end{array}$ & $\begin{array}{l}\text { Krainer et al. (2015) } \\
\text { Calderoni et al. (1998), Dramis et al. (2003) } \\
\text { Calderoni et al. (1998), Stenni et al. (2007), Scapozza et al. (2010) }\end{array}$ \\
\hline \multirow{3}{*}{ LIA } & Southern Alps & Active rock glaciers at $2500 \mathrm{~m}$ on average & LIA-present & Ribolini et al. (2010) \\
\hline & Western Alps & Active rock glaciers at $2647 \mathrm{~m}$ on average & LIA-present & Guglielmin and Smiraglia (1997) \\
\hline & $\begin{array}{l}\text { Central Alps } \\
\text { Julian Alps }\end{array}$ & Active rock glaciers at $2526 \mathrm{~m}$ on average & LIA-present & Guglielmin and Smiraglia (1997), Seppi et al. (2012) \\
\hline \multirow{3}{*}{ Present-day } & Southern Alps & Active rock glaciers at $2500 \mathrm{~m}$ on average & & Ribolini et al. (2010) \\
\hline & Western Alps & Active rock glaciers at $2647 \mathrm{~m}$ on average & & Guglielmin and Smiraglia (1997) \\
\hline & $\begin{array}{l}\text { Central Alps } \\
\text { Julian Alps }\end{array}$ & $\begin{array}{l}\text { Active rock glaciers at } 2526 \mathrm{~m} \text { on average } \\
\text { BTS measurements suggest permafrost at } 2258 \mathrm{~m}\end{array}$ & & Guglielmin and Smiraglia (1997), Seppi et al. (2012), Colucci et al. (2016a) \\
\hline
\end{tabular}


Table 4. Periglacial processes and landforms in the Italian Peninsula since the Last Glaciation until today.

\begin{tabular}{|c|c|c|c|c|}
\hline Phase & Areas & Environment: landforms and processes & $\begin{array}{c}\text { Chronology } \\
\text { (ka BP) }\end{array}$ & References \\
\hline $\begin{array}{c}\text { Last } \\
\text { Glaciation }\end{array}$ & $\begin{array}{l}\text { Northern Appenines } \\
\text { Central Appenines } \\
\text { Southern Appenines }\end{array}$ & $\begin{array}{l}\text { Rock glaciers around } 2000 \mathrm{~m} \text {. Block streams at Mt. Beigua, } \\
\text { Stratified scree slopes } \\
\text { Several rock glaciers around the highest mountain. Stratified scree } \\
\text { slope from the coast upward; cryoturbation in the Mt. Beigua area } \\
\text { One rock glacier at Mt. Pollino and several stratified scree slopes } \\
\text { and one sand wedge at } 1350 \mathrm{~m} \text { at Sila Mountain. Cryoturbation at } \\
\text { Cilento Mountains at } 30 \mathrm{~m}\end{array}$ & $\begin{array}{l}\text { LGM-YD } \\
\text { LGM-YD } \\
\text { LGM-YD }\end{array}$ & $\begin{array}{l}\text { Chelli and Tellini (2002), Firpo et al. (2006), Federici (1981), Rellini et al. } \\
(2014) \\
\text { Coltorti et al. (1979), Castiglioni et al. (1979), Boenzi (1980), Giraudi } \\
\text { (2002) } \\
\text { Dimase (2006), Scarciglia et al. (2003) }\end{array}$ \\
\hline \multicolumn{5}{|l|}{ Deglaciation } \\
\hline Holocene & Central Appenines & $\begin{array}{l}\text { A few rock glaciers developed at } 1900-2000 \mathrm{~m} \text { around the highest } \\
\text { mountains }\end{array}$ & $>7$ & Dramis et al. (2003) \\
\hline LIA & Central Appenines & $\begin{array}{l}\text { One rock glacier is still active at } 2520 \mathrm{~m} \text { at La Majella Mountain. } \\
\text { Permafrost can be present around the highest mountains at more than } \\
2200 \mathrm{~m}\end{array}$ & & Dramis and Kotarba (1992), Dramis et al. (2003) \\
\hline Present-day & Central Appenines & $\begin{array}{l}\text { Permafrost is documented at more than } 2300 \mathrm{~m} \text { around La Majella } \\
\text { and Mt. Velino by BTS measurements }\end{array}$ & & Bisci et al. (2003), Guglielmin (unpublished) \\
\hline
\end{tabular}


Table 5. Periglacial processes and landforms in the Balkan Peninsula since the Last Glaciation until today.

\begin{tabular}{|c|c|c|c|c|}
\hline Phase & Areas & Environment: landforms and processes & $\begin{array}{l}\text { Chronology } \\
\text { (ka BP) }\end{array}$ & References \\
\hline \multirow{3}{*}{$\begin{array}{c}\text { Last } \\
\text { Glaciation }\end{array}$} & Dinaric Alps* & Probable discontinuous permafrost, ice wedges, cryoturbations & & $\begin{array}{l}\text { Liedtke (1962), van Vliet-Lanoe et al. (2004), Ruszkiczay-Rüdiger and } \\
\text { Kern (2015) }\end{array}$ \\
\hline & $\begin{array}{l}\text { Bulgarian } \\
\text { Mountains }\end{array}$ & $\begin{array}{l}\text { Discontinuous and sporadic permafrost above } 1200 \mathrm{~m} \text {, rock glaciers, } \\
\text { block streams, patterned ground }\end{array}$ & & $\begin{array}{l}\text { King and Akerman (1993), Van Vliet-Lanoë and Hallegouët (2001), } \\
\text { Dobinski (2005), Gikov and Dimitrov (2011), Dimitrov and Gikov (2012), } \\
\text { Kuhlemann et al. (2013) }\end{array}$ \\
\hline & $\begin{array}{l}\text { Mountains in } \\
\text { Greece }\end{array}$ & $\begin{array}{l}\text { Probable discontinuous permafrost, ice wedges, cryoturbations, } \\
\text { patterned ground } \\
\text { Glacial cirques: possible rock glacier formation above } \sim 1800 \mathrm{~m}\end{array}$ & & Hughes et al. (2003) \\
\hline \multirow{3}{*}{ Deglaciation } & Dinaric Alps* & Glacial cirques: possible rock glacier formation above $\sim 1700 \mathrm{~m}$ & & Palmentola et al. (1995) \\
\hline & $\begin{array}{l}\text { Bulgarian } \\
\text { Mountains }\end{array}$ & $\begin{array}{l}\text { Discontinuous and sporadic permafrost above } 1950-2000 \mathrm{~m} \text {, rock } \\
\text { glaciers, block streams, patterned ground }\end{array}$ & OD, YD & $\begin{array}{l}\text { King and Akerman (1993), Dobinski (2005), Gikov and Dimitrov (2011), } \\
\text { Dimitrov and Gikov (2012), Kuhlemann et al. (2013) }\end{array}$ \\
\hline & $\begin{array}{l}\text { Mountains in } \\
\text { Greece }\end{array}$ & $\begin{array}{l}\text { Glacial cirques: possible rock glacier formation above } \sim 2100 \mathrm{~m} \text { (age } \\
\text { uncertain, probably multiple generations of rock glacier in Greece } \\
\text { with altitudinal ranges of } 1330-2300 \mathrm{~m} \text { ) }\end{array}$ & age uncertain & Palmentola and Stamatopoulos (2004), Hughes et al. (2006a) \\
\hline \multirow{2}{*}{ Holocene } & $\begin{array}{l}\text { Bulgarian } \\
\text { Mountains }\end{array}$ & $\begin{array}{l}\text { Discontinuous and sporadic permafrost, rock glaciers, block streams } \\
\text { (?) }\end{array}$ & & $\begin{array}{l}\text { Gikov and Dimitrov (2011), Dimitrov and Gikov (2012), Kuhlemann et al. } \\
\text { (2013) }\end{array}$ \\
\hline & $\begin{array}{l}\text { Mountains in } \\
\text { Greece }\end{array}$ & Perennial snowfields, possible sporadic permafrost & & Styllas et al. (2015) \\
\hline \multirow{3}{*}{ LIA } & Dinaric Alps* & $\begin{array}{l}\text { Highest cirques: presence of small cirque glaciers above } \sim 1850 \mathrm{~m} \text {, } \\
\text { greater abundance of snow patches }\end{array}$ & & Hughes $(2010,2014)$ \\
\hline & $\begin{array}{l}\text { Bulgarian } \\
\text { Mountains }\end{array}$ & $\begin{array}{l}\text { Discontinuous and sporadic permafrost, rock glaciers, glacierets and } \\
\text { small cirque glaciers, perennial snow patches }\end{array}$ & & Grünewald et al. (2008), Gachev et al. (2016) \\
\hline & $\begin{array}{l}\text { Mountains in } \\
\text { Greece }\end{array}$ & $\begin{array}{l}\text { Perennial snowfields, greater abundance of snow patches. Sporadic } \\
\text { permafrost. Possibly small cirque glaciers on Mt Olympus }\end{array}$ & & Styllas et al. (2015) \\
\hline \multirow{3}{*}{ Present-day } & Dinaric Alps* & $\begin{array}{l}\text { Karst depressions: cryo and ice caves above } \sim 800 \mathrm{~m} \\
\text { Highest cirques: permanent firn/ice features above } 1910 \mathrm{~m} \\
\text { Probable sporadic permafrost above } 2300 \mathrm{~m}\end{array}$ & & $\begin{array}{l}\text { Brown et al. (2001), Dobinski (2005), Kern et al. (2006), Mihevc (2008), } \\
\text { Milivojević et al. (2008), Hughes (2009), Bočić et al. (2014), Košutnik et al. } \\
\text { (2014), Gachev et al. (2016), Buzjak et al. (2016), Zupan Hajna (2016) }\end{array}$ \\
\hline & $\begin{array}{l}\text { Bulgarian } \\
\text { Mountains }\end{array}$ & $\begin{array}{l}\text { Sporadic permafrost, glacierets and small cirque glaciers, perennial } \\
\text { snow patches }\end{array}$ & & $\begin{array}{l}\text { Grünewald et al. (2008), Grünewald and Scheithauer (2010), Nojarov } \\
(2012 a, b) \text {, Gachev et al. (2016) }\end{array}$ \\
\hline & $\begin{array}{l}\text { Mountains in } \\
\text { Greece }\end{array}$ & Perennial snowfields, probable sporadic permafrost above $2700 \mathrm{~m}$ & & Styllas et al. (2015) \\
\hline
\end{tabular}

*Slovenia, Croatia, Bosnia and Herzegovina, Montenegro, Albania 
Table 6. Altitudinal range of rock glaciers in the Balkan Peninsula.

\begin{tabular}{|c|c|c|c|}
\hline Location & Min altitude (m) & Max altitude (m) & Data source \\
\hline Pindus Mountains & 1330 & 2300 & $\begin{array}{c}\text { Hughes et al. (2003), Palmentola } \\
\text { and Stamatopoulos (2006) }\end{array}$ \\
\hline Pirin Mountains & 2090 & 2700 & Dimitrov and Gikov (2012) \\
\hline Rila Mountains & 2140 & 2690 & Gikov and Dimitrov (2011) \\
\hline Prokletije Mountains & 1700 & 2120 & Palmentola et al. (1995) \\
\hline Mount Korab & 1480 & 2600 & this paper \\
\hline Šar Mountains & 1750 & 2250 & Kuhlemann et al. (2009) \\
\hline $\begin{array}{c}\text { Dinaric Alps } \\
\text { (without Prokletije) }\end{array}$ & 1650 & 2150 & this paper \\
\hline
\end{tabular}


Table 7. Periglacial processes and landforms in the Anatolia Peninsula since the Last Glaciation until today.

\begin{tabular}{|c|c|c|c|c|}
\hline Phase & Areas & Environment: landforms and processes & $\begin{array}{l}\text { Chronology } \\
\text { (ka BP) }\end{array}$ & References \\
\hline \multirow{5}{*}{ Last Glaciation } & Western Taurus Mts. & $\begin{array}{l}\text { Glaciated summit plateaus above } 2400 \mathrm{~m} \text { : strong glacial and karst } \\
\text { control on the intensity of periglacial activities } \\
\text { Periglacial processes below LGM snowline }(2000-2500 \mathrm{~m})\end{array}$ & & $\begin{array}{l}\text { Messerli (1967), Çiner (2004), Sarıaya et al. (2008, } \\
\text { 2014), Zahno et al. (2009), Çılğın (2015), Çiner et al. } \\
\text { (2015), Köse et al. (2017), Sarıkaya and Çiner (2017), } \\
\text { Sarıkaya et al. (2017) }\end{array}$ \\
\hline & Central Taurus Mts. & $\begin{array}{l}\text { Glaciated summit plateaus above } 3000 \mathrm{~m} \text { : strong glacial and karst } \\
\text { control on the intensity of periglacial activities } \\
\text { Periglacial processes below LGM snowline }(2650-2700 \mathrm{~m})\end{array}$ & & $\begin{array}{l}\text { Zreda et al. (2011), Çiner and Sarıkaya (2017), Sarıkaya } \\
\text { and Çiner (2017) }\end{array}$ \\
\hline & Southeastern Taurus Mts. & Periglacial processes below LGM snowline (2100-2800 m) & & Sarıkaya and Çiner (2015), Yeşilyurt et al. (2016) \\
\hline & Eastern Black Sea Mts. & $\begin{array}{l}\text { Periglacial processes below LGM snowline }(2300-2500 \mathrm{~m}) \text {, relict rock } \\
\text { glaciers }\end{array}$ & & $\begin{array}{l}\text { Erinç, (1952), Messerli (1967), Çiner, (2004), Akçar et } \\
\text { al. (2007, 2008), Reber et al. (2014) }\end{array}$ \\
\hline & Karçal (Lesser Caucasus Mts.) & Relict rock glaciers $(2540-2430 \mathrm{~m})$ & & Dede et al. $(2015,2017)$ \\
\hline \multirow{6}{*}{ Deglaciation } & Western Taurus Mts. & Strong glacial and karst control on the intensity of periglacial activities & & $\begin{array}{l}\text { Zahno et al. (2009), Çiner et al. (2015), Sarıkaya et al. } \\
(2008,2014) \text {, Sarıkaya and Çiner (2017) }\end{array}$ \\
\hline & Central Taurus Mts. & $\begin{array}{l}\text { Glaciated summit plateaus } \\
\text { Strong glacial and karst control on the intensity of periglacial activities } \\
\text { (rock falls, mass movements, rock glaciers, patterned grounds) }\end{array}$ & & $\begin{array}{l}\text { Çılğın (2015), Sarıkaya et al. (2008, 2014, 2017), Çiner } \\
\text { et al. (2015), Zreda et al. (2011), Çiner and Sarıkaya } \\
\text { (2017), Sarıkaya and Çiner (2017) }\end{array}$ \\
\hline & Southeastern Taurus Mts. & Relict rock glaciers & & Çiner (2003), Sarıkaya and Çiner (2015) \\
\hline & Eastern Black Sea Mts. & Relict rock glaciers & & Akçar et al. $(2007,2008)$, Reber et al. (2014) \\
\hline & Karçal (Lesser Caucasus Mts.) & Relict rock glaciers $(2540-2400 \mathrm{~m})$, protalus lobes & 15 & Dede et al. $(2015,2017)$ \\
\hline & Mercan & Relict rock glaciers & & Bilgin (1972) \\
\hline \multirow{8}{*}{ Holocene } & Western Taurus Mts. & $\begin{array}{l}\text { Non-glaciated summit plateaus: strong karst control on the intensity of } \\
\text { periglacial activities }\end{array}$ & & $\begin{array}{l}\text { Arpat and Özgül (1972), Çiner et al. (1999, 2015), Çıl̆ğın } \\
\text { (2015), Sarıkaya et al. (2008, 2014), Zahno et al. (2009), } \\
\text { Sarıkaya and Çiner (2017) }\end{array}$ \\
\hline & Central Taurus Mts. & $\begin{array}{l}\text { Non-glaciated summit plateaus: strong karst control on the intensity of } \\
\text { periglacial activities, rock glaciers }(1800 \mathrm{~m})\end{array}$ & $>6$ & $\begin{array}{l}\text { Arpat and Özgül (1972), Çiner et al. (1999, 2015, 2017), } \\
\text { Zreda et al. (2011) Çiner and Sarıaya (2017), Sarıkaya } \\
\text { et al. (2017) }\end{array}$ \\
\hline & Southeastern Taurus Mts. & Strong glacial control on the intensity of periglacial activities & & İzbıkak (1951), Erinç (1953) \\
\hline & Eastern Black Sea Mts. & Non-glaciated summit plateaus, rock glaciers & & Akçar et al. (2007, 2008), Reber et al. (2014) \\
\hline & Karçal (Lesser Caucasus Mts.) & Rock glaciers (2935-2730 m) & & Dede et al. $(2015,2017)$ \\
\hline & Ilgaz & Block flows, cyroplanation surfaces & & Erinç et al. (1961) \\
\hline & Erciyes & $\begin{array}{l}\text { Early to late Holocene glacial advances implying periglacial conditions } \\
\text { surrounding the glaciers }\end{array}$ & & Sarıkaya et al. (2009) \\
\hline & Ağrı (Ararat) & Debris on the slopes and blocky colluvium in the valley floor & & Avcı (2007), Sarıkaya (2012), Azzoni et al. (2017) \\
\hline
\end{tabular}




\begin{tabular}{|c|c|c|c|c|}
\hline \multirow{5}{*}{ LIA } & Western Taurus Mts. & Rock glaciers & & $\begin{array}{l}\text { Çiner et al. (2015), Sarıkaya et al. }(2014,2017) \text { Sarıkaya } \\
\text { and Çiner (2017) }\end{array}$ \\
\hline & Central Taurus Mts. & Rock debris on glaciers, rock glaciers $(1800 \mathrm{~m})$ & $>6$ & $\begin{array}{l}\text { Altın (2006), Gürgen et al. (2010), Çiner and Sarıkaya } \\
\text { (2017), Sarıkaya et al. (2017) }\end{array}$ \\
\hline & Eastern Black Sea Mts. & Rock glaciers, protalus lobes & & $\begin{array}{l}\text { Doğu et al. (1993), Akçar et al. (2007, 2008), Bayrakdar } \\
\text { and Özdemir (2010), Reber et al. (2014) }\end{array}$ \\
\hline & Karçal (Lesser Caucasus Mts.) & Rock glaciers $(2935-2730 \mathrm{~m})$, protalus lobes & & Dede et al. $(2015,2017)$ \\
\hline & Uludağ & Moraines in cirque areas with periglacial landforms & & $\begin{array}{l}\text { Erinç (1952), Birman (1968), Zahno et al. (2010), Akçar } \\
\text { et al. (2014, 2015) }\end{array}$ \\
\hline \multirow{13}{*}{ Present-day } & Western Taurus Mts. & $\begin{array}{l}\text { Non-glaciated summit plateaus; active karst influence on periglacial } \\
\text { landforms, rock glaciers }(2500-2800 \mathrm{~m})\end{array}$ & & $\begin{array}{l}\text { Dellanoy and Maire (1983), Sarıkaya et al. (2014), } \\
\text { Sarıkaya and Çiner (2015) }\end{array}$ \\
\hline & Central Taurus Mts. & $\begin{array}{l}\text { Debris covered glaciers } \\
\text { Cave ice at } 3000 \mathrm{~m} \\
\text { Stone stripes at } 3200 \mathrm{~m}\end{array}$ & & $\begin{array}{l}\text { Bayarı et al. (2003), Klimchouk et al. (2006), Çalışkan et } \\
\text { al. (2012) }\end{array}$ \\
\hline & Southeastern Taurus Mts. & Rock glaciers & & Doğu (2009) \\
\hline & Eastern Black Sea Mts. & $\begin{array}{l}\text { Stone circles }(1800 \mathrm{~m}) \text { and ovoid depressions }(1900 \mathrm{~m}) \\
\text { Solifluction terraces, frost creep and mass movements (rock falls, } \\
\text { talus, talus creeps, rock avalanches and rock flows) } \\
\text { Garland soils, rock glaciers }\end{array}$ & & $\begin{array}{l}\text { de Planhol and Bilgin (1964), Bilgin (1969), Gürgen } \\
\text { (2001), Akçar and Schlüchter (2005), Çiçek et al. (2006), } \\
\text { Turoğlu (2009), Gorbunov (2012), Reber et al. (2014) }\end{array}$ \\
\hline & Karçal (Lesser Caucasus Mts.) & $\begin{array}{l}\text { Rock glaciers between } 2935-2730 \mathrm{~m} \\
\text { Protalus lobes at ca. } 2000 \mathrm{~m}\end{array}$ & & Dede et al. $(2015,2017)$, Çalışkan $(2016)$ \\
\hline & Kazdağ & $\begin{array}{l}\text { Relict block streams }(1350 \mathrm{~m}) \\
\text { Garland soils }(1700 \mathrm{~m})\end{array}$ & & Bilgin (1960) \\
\hline & Uludağ & $\begin{array}{l}\text { The best-described mountain concerning periglacial landforms } \\
\text { Garland soils }(1900-2300 \mathrm{~m}) \\
\text { Stone accumulations }>2300 \mathrm{~m}\end{array}$ & & $\begin{array}{l}\text { Erinç (1949, 1957), Zahno et al. (2010), Türkeş and } \\
\text { Öztürk (2008, 2011), Öztürk (2012), Akçar et al. (2014, } \\
\text { 2015) }\end{array}$ \\
\hline & Ilgaz & Small stone circles and garlands & & Erinç et al. (1961) \\
\hline & Esence & Garlands and polygonal soils $>2500 \mathrm{~m}$ & & Akkan and Tuncel (1993) \\
\hline & Mercan & Debris covered glaciers mistakenly interpreted as rock glaciers & & Yeşilyurt and Doğan (2010) \\
\hline & Mescid & Stone rings $>2650 \mathrm{~m}$ & & Atalay (1983) \\
\hline & Erciyes & Rock glacier $(2950 \mathrm{~m})$ & & Sarıkaya et al. (2003, 2009), Ünal and Sarıkaya (2013) \\
\hline & Ağrı (Ararat) & $\begin{array}{l}\text { Ice cap of which } 1.82 \mathrm{~km}^{2} \text { is debris-covered } \\
>4000 \mathrm{~m} \text { : a large recently deglaciated area } \\
3000 \text { to } 4000 \mathrm{~m} \text {; gravitational processes (mass wasting) }\end{array}$ & & $\begin{array}{l}\text { Sarkkaya (2012), Yavaşlı et al. (2015), Azzoni et al. } \\
\text { 2017) }\end{array}$ \\
\hline
\end{tabular}


Table 8. Periglacial processes and landforms in northern Africa since the Last Glaciation until today.

\begin{tabular}{|c|c|c|c|c|}
\hline Phase & Areas & Environment: landforms and processes & $\begin{array}{l}\text { Chronology } \\
\text { (ka BP) }\end{array}$ & References \\
\hline \multirow{8}{*}{ Last Glaciation } & Hoggar & Nivation forms $(>2400 \mathrm{~m})$, frost action $(<2000 \mathrm{~m})$ & & Messerli (1973) \\
\hline & Tibesti & Nivation forms $(>3000 \mathrm{~m})$, frost action $(<2000 \mathrm{~m})$ & & Messerli (1973) \\
\hline & Aurès Massif & Nivation forms (> $1800 \mathrm{~m})$, stratified slope deposits (> $1800 \mathrm{~m})$ & & Tihay (1973) \\
\hline & Algerian High Plateaux & Nivation $(>1500 \mathrm{~m})$ & & Marre and Quinif (1981) \\
\hline & Algerian Tell & $\begin{array}{l}\text { Nivation forms }(>1500 \mathrm{~m}) \text {, stratified slope deposits }(>1400 \mathrm{~m}) \text {, } \\
\text { possible rock glaciers }(>1100 \mathrm{~m})\end{array}$ & & Tihay (1973) \\
\hline & Rif & Rock glaciers, perennial snowpatches & & Mensching (1960) \\
\hline & Middle Atlas & $\begin{array}{l}\text { Possible rockglaciers }(2100-2500 \mathrm{~m}) \text {, stone circles (?), solifluction } \\
\text { features (?), stratified slope deposits }\end{array}$ & & $\begin{array}{l}\text { Dresch and Raynal (1953), Raynal et al. (1956), Awad } \\
\text { (1963), this paper }\end{array}$ \\
\hline & High Atlas & Stratified slope deposits & & Chardon and Riser (1981) \\
\hline Deglaciation & High Atlas & $\begin{array}{l}\text { Possible rock glaciers (M'Goun Massif) (but possibly also in the } \\
\text { Middle Atlas) }\end{array}$ & & Wiche (1953) \\
\hline \multirow{6}{*}{ Present-day } & Hoggar & No active periglacial processes & & Messerli (1973) \\
\hline & Tibesti & No active periglacial processes & & Messerli (1973) \\
\hline & Aurès Massif & Frost action $(2300 \mathrm{~m})$, solifluction $(1300-1800 \mathrm{~m})$ & & Tihay (1973), Ballais (1981) \\
\hline & Algerian Tell & Nivation $(1800 \mathrm{~m})$, frost action $(1500 \mathrm{~m})$ & & Tihay (1973) \\
\hline & High Atlas & $\begin{array}{l}\text { Possibly active talus rock glaciers/lobe }(>3700 \mathrm{~m}) \text {, possible } \\
\text { permafrost }(3800 \mathrm{~m}) \text {, frost shattering }(>2500 \mathrm{~m}) \text {, solifluction lobes } \\
(3900 \mathrm{~m})\end{array}$ & & $\begin{array}{l}\text { Chardon and Riser (1981), Hughes et al. (2011), Hughes } \\
\text { (2017), Vieira et al. (2017) }\end{array}$ \\
\hline & Middle Atlas & $\begin{array}{l}\text { Frost shattering, terracettes/vegetation crescents, shallow solifluction } \\
(2700 \mathrm{~m} \text { at Djebel Bou Naceur) }\end{array}$ & & $\begin{array}{l}\text { Dresch and Raynal (1952), Raynal et al. (1956), this } \\
\text { paper }\end{array}$ \\
\hline
\end{tabular}

